UNITED STATES

DEPARTMENT OF THE INTERIOR

GEOLOGICAL SURVEY

\title{
LOCATION REFINEMENT OF EARTHQUAKES IN THE \\ SOUTHWESTERN GREAT BASIN, 1931-1974, AND SEISMOTECTONIC CHARACTERISTICS OF SOME OF THE IMPORTANT EVENTS
}

by

W.H. Gawthrop and W.J. Carr

Open-File Report 88-560

\footnotetext{
Prepared in cooperation with the

U.S. Department of Energy

(Interagency Agreement DE-AI08-78ET44802)
}

This report is preliminary and has not been reviewed for conformity with U.S. Geological Survey editorial standards and stratigraphic nomenclature. Any use of trade names is for descriptive purposes only and does not imply endorsement by the USGS.

$$
\begin{gathered}
\text { Denver, Colorado } \\
\text { i988 }
\end{gathered}
$$




\title{
Copies of this Open-File Report may be purchased from
}

\author{
Books and Open-File Reports Section \\ Branch of Distribution \\ U.S. Geological Survey \\ Box 25425 Federal Center \\ Denver, Colorado 80225
}

\author{
PREPAYMENT IS REQUIRED \\ Price information will be published \\ in the monthly listing \\ "New Publications of the Geological Survey"
}

FOR ADDITIONAL ORDERING INFORMATION

CALL: Commerical: (303) 236-7476

FTS: $776-7476$ 


\title{
LOCATION REFINEMENT OF EARTHQUAKES IN THE SOUTHMESTERN GREAT BASIN, 1931-1974, AND SEISMOTECTONIC CHARACTERISTICS OF SOME OF THE IMPORTANT EVENTS
}

\author{
by
}

W.H. Gawthrop ${ }^{1}$ and W.J. Carr ${ }^{2}$

IGreen Mountain Geophysics, Inc., Boulder, Colorado

¿Formerly with U.S. Geological Survey, now consultant to Sandia National Laboratories 


\section{CONTENTS}

Abstract $\ldots \ldots \ldots \ldots \ldots \ldots \ldots \ldots \ldots \ldots \ldots \ldots \ldots \ldots \ldots \ldots \ldots \ldots \ldots \ldots \ldots \ldots \ldots \ldots 1$

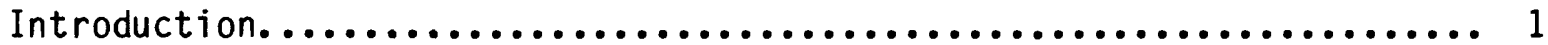

Sources of data................................... 3

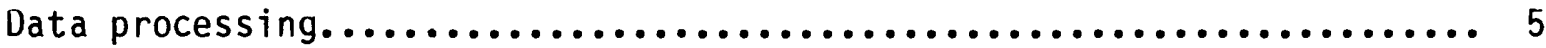

Velocity structure and station-phase corrections............. 5

Event location processing................................ 5

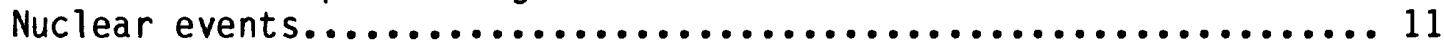

Results of earthquake relocation................................ 11

Interpretation of data..................................... 11

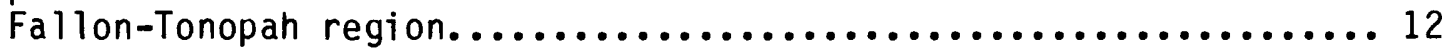

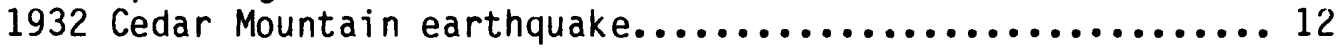

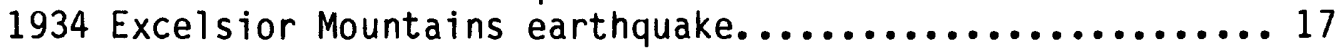

1954 Fallon-Stillwater (Rainbow Mountain) sequence.......... 17

1954 Fairview Peak earthquake........................... 21

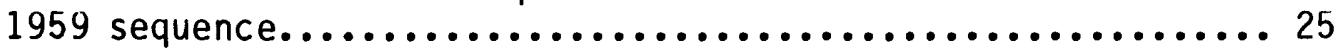

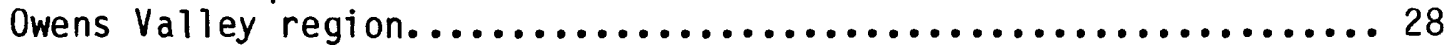

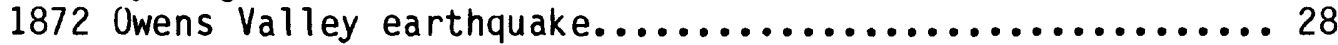

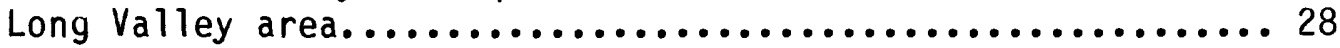

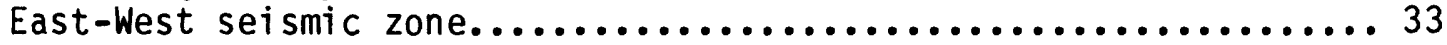

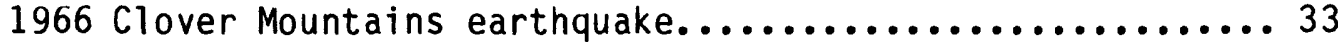

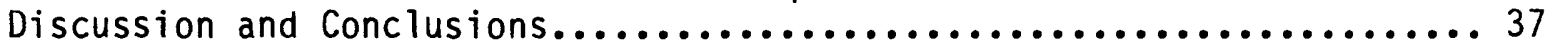

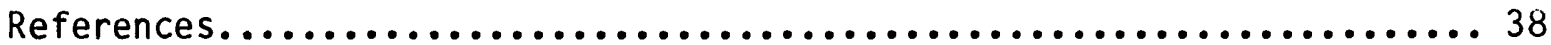

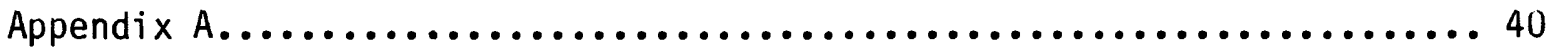

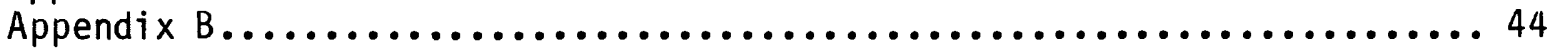

\section{ILLUSTRATIONS}

Plate 1. Epicenters 1931 through 1974 relocated in this study In pocket

Figure 1. Map showing region of earthquake relocation study, showing major seismic zones and location of important earthquake sequences discussed in this report............ 2

2. B-value diagram: number of events in this study plotted against the magnitude of the events............. 4

3. Map showing locations of the master events used for determining the traveltime curves shown in figure 4....... 6

4. Traveltime curves of the model used for the relocation of the epicenters in this study............ 7

5. Map showing 90-percent confidence ellipses for 1931-1963 earthquakes studied..................... 8

6. Map showing 90-percent confidence ellipses for 1964-1974 earthquakes studied........................ 9

7. 90-percent confidence ellipses for nuclear explosions

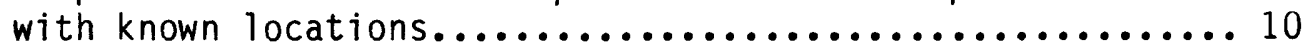

8. Map showing fault pattern in the Fallon-Tonopah region showing surface ruptures (dotted lines) and month and year of main events discussed in this report. Dashed ines indicate approximate aftershock zone boundaries...... 13 


\section{ILLUSTRATIONS--Continued}

Page

Figure 9. Map showing relocated 1931-1963 epicenters in FallonTonopah region................................... 14

10. Map showing 90-percent confidence ellipses for relocated 1931-1963 earthquakes in Fallon-Tonopah region............ 15

11. Map showing location of 1932 Cedar Mountain earthquake..... 16

12. Focal mechanism plot for the 1932 Cedar Mountain earthquake..................................... 18

13. Map showing 1934 Excelsior Mountains earthquake........... 19

14. Map showing July 1954 Fallon-Stillwater earthquake......... 20

15. Map showing August 1954 Fallon-Stillwater earthquake....... 22

16. Map showing 1954 Fairview Peak earthquake................. 23

17. Focal mechanism plot for the 1954 Fallon-Stillwater

(Rainbow Mountain) composite.......................... 24

18. Focal mechanism plot for the 1954 Fairview Peak

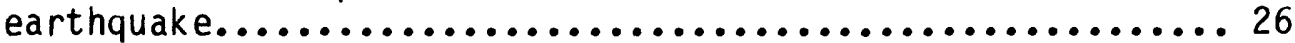

19. Map showing 1959 earthquake sequence................... 27

20. Map showing fault pattern in the Owens Valley region....... 29

21. Owens Valley earthquakes 1931-1974.................... 30

22. 90-percent confidence ellipses for epicenters

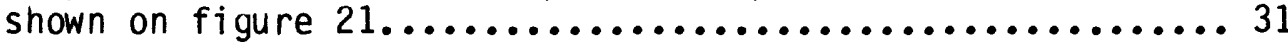

23. Focal mechanism plot for the Owens Valley fault zone earthquakes; composite plot of several events........ 32

24. Focal mechanism plot for the Long Valley composite of five earthquakes............................... 34

25. Map showing east-west seismic zone between the Nevada Test Site and Utah-Nevada border............... 35

26. 1966 Clover Mountains earthquake. 90 percent confidence ellipses for earthquakes.................. 36 


\title{
LOCATION REFINEMENT OF EARTHQUAKES IN THE SOUTHWESTERN GREAT BASIN, 1931-1974, AND SEISMOTECTONIC CHARACTERISTICS OF SOME OF THE IMPORTANT EVENTS
}

\author{
by \\ W.H. Gawthrop and W.J. Carr
}

\begin{abstract}
Seismological records for the period 1931-1974 were examined and analyzed by modern techniques, including velocity structure inversion and application of station-phase corrections. Epicenter confidence ellipses and fault plane solutions were determined for many events. In the past, epicenters of earthquakes in the southwestern Great Basin have been mislocated by as much as $100 \mathrm{kilometers,} \mathrm{or} \mathrm{even} \mathrm{more} \mathrm{in} \mathrm{one} \mathrm{case.} \mathrm{Improved} \mathrm{locations} \mathrm{for} \mathrm{foreshocks}$ and aftershocks, with relative errors of about 5 to $10 \mathrm{kilometers}$ and absolute errors of perhaps 15 to $25 \mathrm{kilometers,} \mathrm{permit} \mathrm{closer} \mathrm{inspection} \mathrm{of} \mathrm{possible}$ relationships or coupling between some major events in the Nevada portion of the Nevada-California seismic zone.
\end{abstract}

\section{INTRODUCTION}

Assessment of seismic risk in western Nevada and easternmost California has become increasingly important in the last few decades. Although much of the Great Basin has been seismically active in the historic past, the older earthquake data have not been fully utilized to help understand the tectonic setting.

This study describes some results of relocation of instrumentallyrecorded earthquakes in the southwestern Great Basin of Nevada and California (fig. 1) for the period 1931-1974. The work was done largely in 1980 by the first author, under contract to the U.S. Geological Survey (USGS). The second author edited the report and prepared the final draft in 1987, as a consultant to Sandia National Laboratories. The work is a contribution to the seismotectonic framework studies being performed by the USGS for the U.S. Department of Energy (Interagency Agreement DE-AI08-78ET44802) for a proposed high-level nuclear waste repository site at the Nevada Test Site.

The authors thank J.W. Dewey of the U.S. Geological Survey for helping to support this study, and for providing technical guidance and assistance. Mark Meremonte of the U.S. Geological Survey recast Appendix A for publication.

The report consists of three main parts: (1) description of the relocation process, (2) discussion and analysis of characteristics of some of the larger historic earthquakes in the region, and (3) appendices of the location data. 


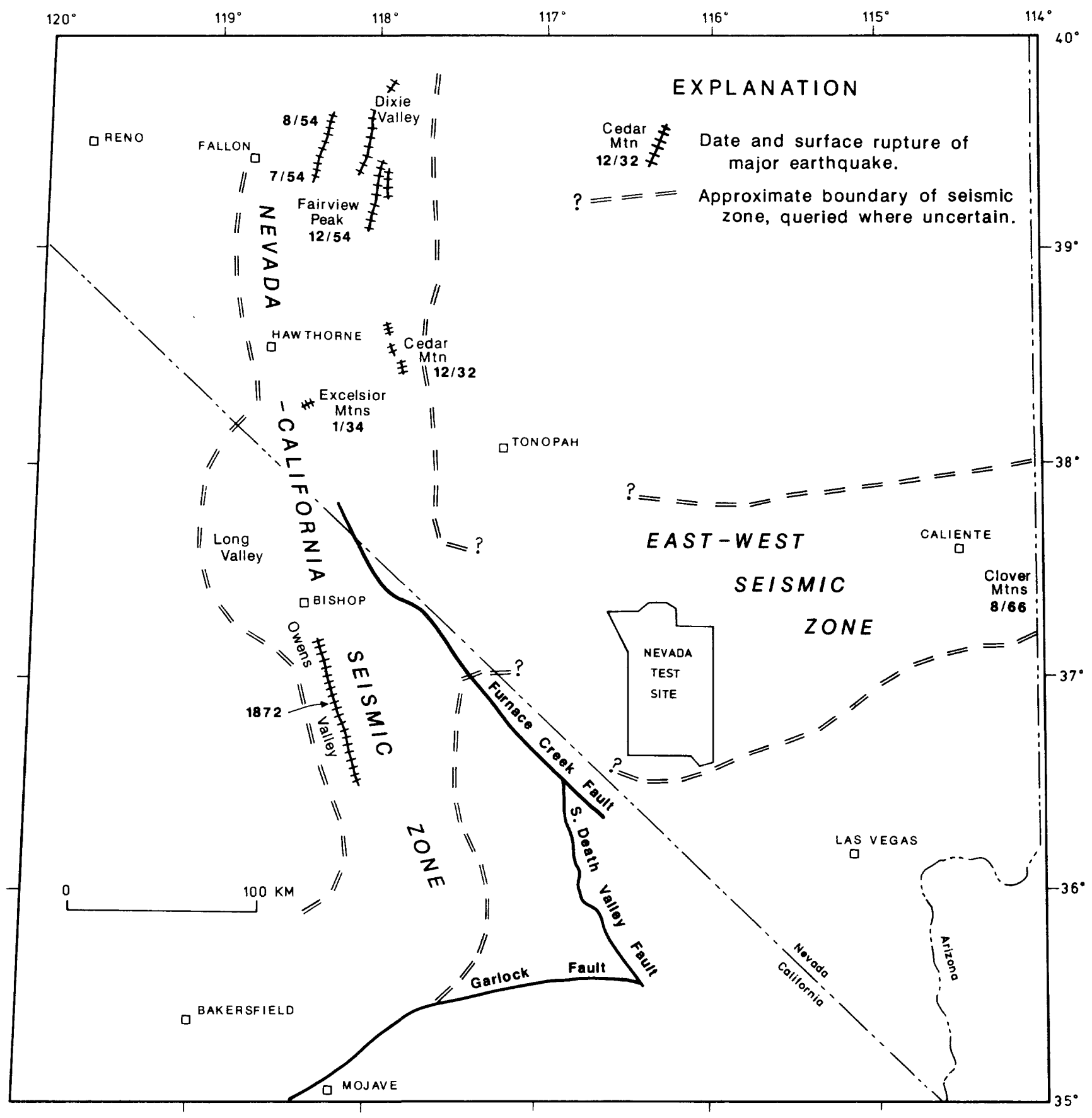

Figure 1.--Region of earthquake relocation study, showing major seismic zones and location of important earthquake sequences discussed in this report. 


\section{Sources of Data}

Instrumental coverage has been available since the early 1930's for location of larger earthquakes in the southwestern Great Basin. Phase arrival-time data for earthquakes between 1931 and 1963 were collected from the International Seismological Summary (ISS), the Bureau Central Internationale de Seismologie (BCIS), from the original reading sheets of seismograph networks based at the University of California at Berkeley (UCB), and from the California Institute of Technology at Pasadena (CIT). In order to expedite the data gathering, phase arrival-time data for earthquakes between 1964 and 1974 were obtained from first arrival-time data in International Seismological Center (ISC) records. These included readings from some local network stations. Earthquakes used for this study were taken from the catalog of Slemmons and others (1965), or from the U.S. Geological Survey epicenter catalog for the pre-1964 events, and from the ISC event catalog for the more recent events. The completeness threshold is estimated at about magnitude 5.5 for the first decade, decreasing approximately a half magnitude unit in each succeeding decade. The addition of a few local seismic networks in the 1960's and early 1970's improved the completeness threshold only within the networks. The local networks typically did not report earthquakes very far beyond the network limits, and thus did not improve the threshold in most of Nevada. The b-value plot (fig. 2) should be a straight line if all the data down to low magnitudes were available. This plot gives an indication of the completeness threshold for the 1931-1963 data, and the modest improvement of the threshold after 1963.

In addition to the relocated epicenters of the foreshocks, mainshocks, and aftershocks of the larger earthquake sequences presented here, some focal mechanisms of these events were determined from fault plane solutions or first motion data. The mechanisms for the two largest events, the 1932 Cedar Mountain earthquake and the 1954 Fairview Peak earthquake, are from replotted first motions read by Byerly (1935) and Romney (1957), respectively, with slight modifications in the interpreted fault planes. The three additional mechanisms are composites of several earthquakes along the fault or in the area of interest. Data for these came from the original reading sheets of the UCB and CIT centers.

The Fallon-Stillwater (Rainbow Mountain) composite fault plane solution was supplemented with data from ISS for North American stations. First motions for arrivals with large traveltime residuals were not used. A few $P$ wave readings whose arrival times corresponded to that of the Pg phase were plotted with take-off angles of $85^{\circ}$, but were not given much weight in determining the fault planes.

Magnitudes listed in this report are those given in the National Earthquake Information Service (NEIS) catalog, and are typically local magnitudes from UCB or CIT. No attempt was made to redetermine magnitudes. 


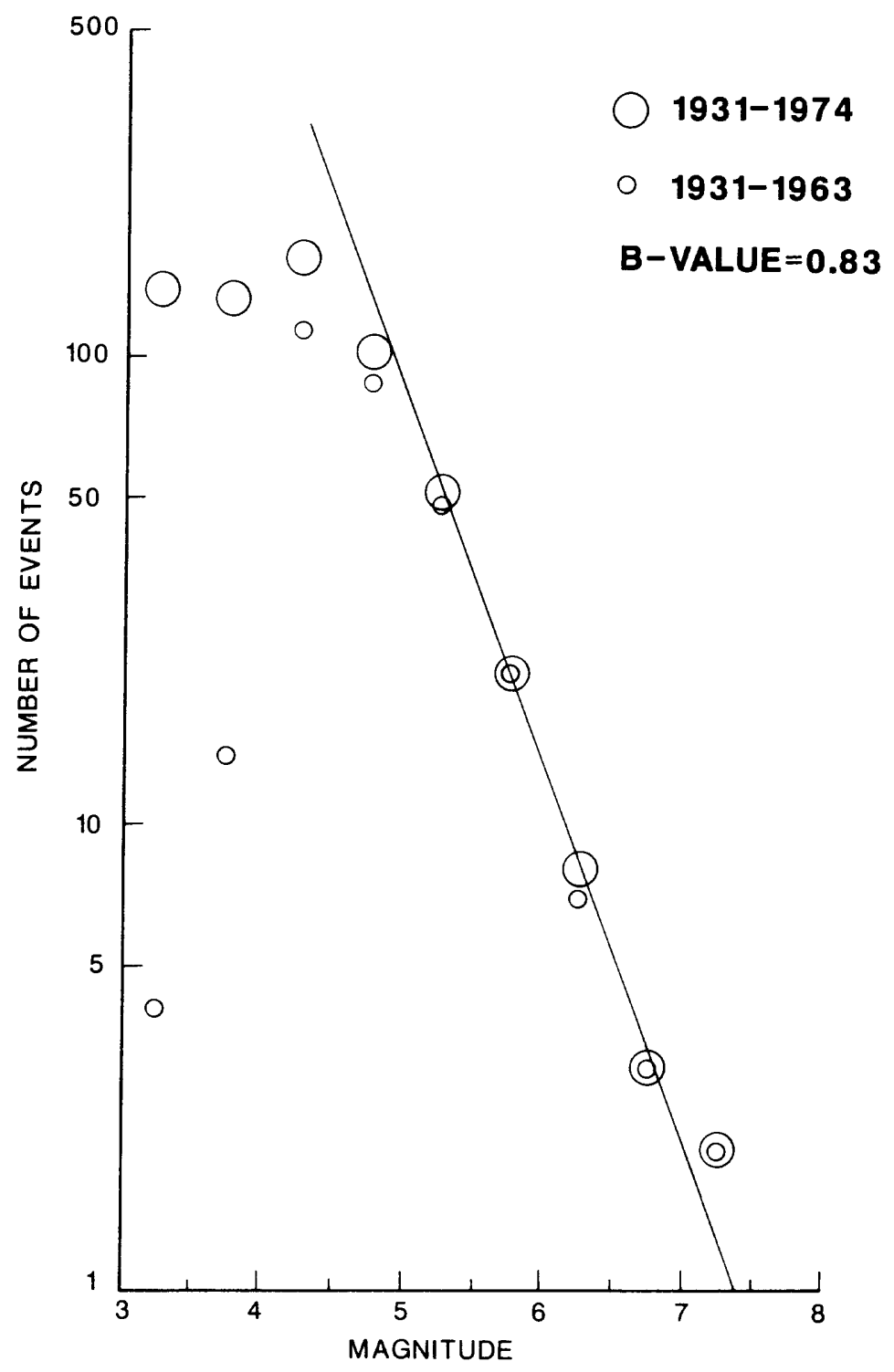

Figure 2.--B-value diayram: number of events in this study plotted against maynitude of the events. 


\section{DATA PROCESSING}

\section{Velocity Structure and Station-Phase Corrections}

Because of the large range of distances from the earthquakes to the seismographs $(0-1,200 \mathrm{~km})$, it was desirable to determine an appropriate velocity structure for the seismic waves propagating through and out of Nevada. Sources chosen for inverting this velocity structure were 10 welllocated seismic sources, 7 earthquakes and 3 nuclear explosions, distributed throughout the region of interest (fig. 3). An inversion program, VELINV, was used to solve for the locations of the seismic sources and for the $\mathrm{Pn}, \mathrm{Pg}, \mathrm{Sn}$, and $\mathrm{Lg}$ wave velocities (fig. 4) as a function of epicentral distance. Station-phase corrections were determined from traveltime residuals of 27 events located using this model. Most stations used only for the 1964-1974 data set had small epicentral distances, and the others all had small traveltime residuals. For the purpose of this study, these stations were left uncorrected. The station locations and their adjustments are given in Appendix A.

\section{Event Location Processing}

Data from all events were preprocessed using the computer program HANJOB. This is an interactive program that allows an approximate location to be made by visual inspection of distance residual versus azimuth plots. For events recorded through a wide range of azimuths, this preprocesser permits previously misidentified phase arrivals to be correctly identified, and arrivals not corresponding to any of the phases modeled to be down-weighted or discarded. Preprocessing greatly improved the speed and accuracy of the relocation procedure. It also brought to light a major problem for earthquake locations in this region: Events with only a few readings from a narrow range of azimuths commonly have two distinct locations, depending on which phases the arrivals represent. These location errors are not accounted for in the confidence ellipses (figs. 5, 6, and 7), because large non-Gaussian errors are not accounted for in the statistical theory used to construct the confidence ellipses. Events most susceptible to mislocation by misidentification of arrival times are those with large elongated ellipses. Events without sufficient data to give any meaningful location were discarded at the preprocessing stage. Approximately 1,200 earthquakes passed preprocessing (Appendix B).

Final locations were determined using HYLOC, a computer program that determines hypocentral locations and confidence regions for seismic events using a velocity model derived from the VELINV program. All events were held fixed at $8.0 \mathrm{~km}$ depth, as few events had close-in coverage adequate to accurately determine focal depths. Assuming that the velocities are correctly modeled and that all errors are truly Gaussian, there is approximately a 90percent probability that the true epicenters lie within the confidence ellipses shown in figures 5 and 6 . As mentioned earlier, confidence ellipses for some of the smaller events may not represent the actual errors due to the phase misidentification problem. However, these events typically have larger ellipses. 


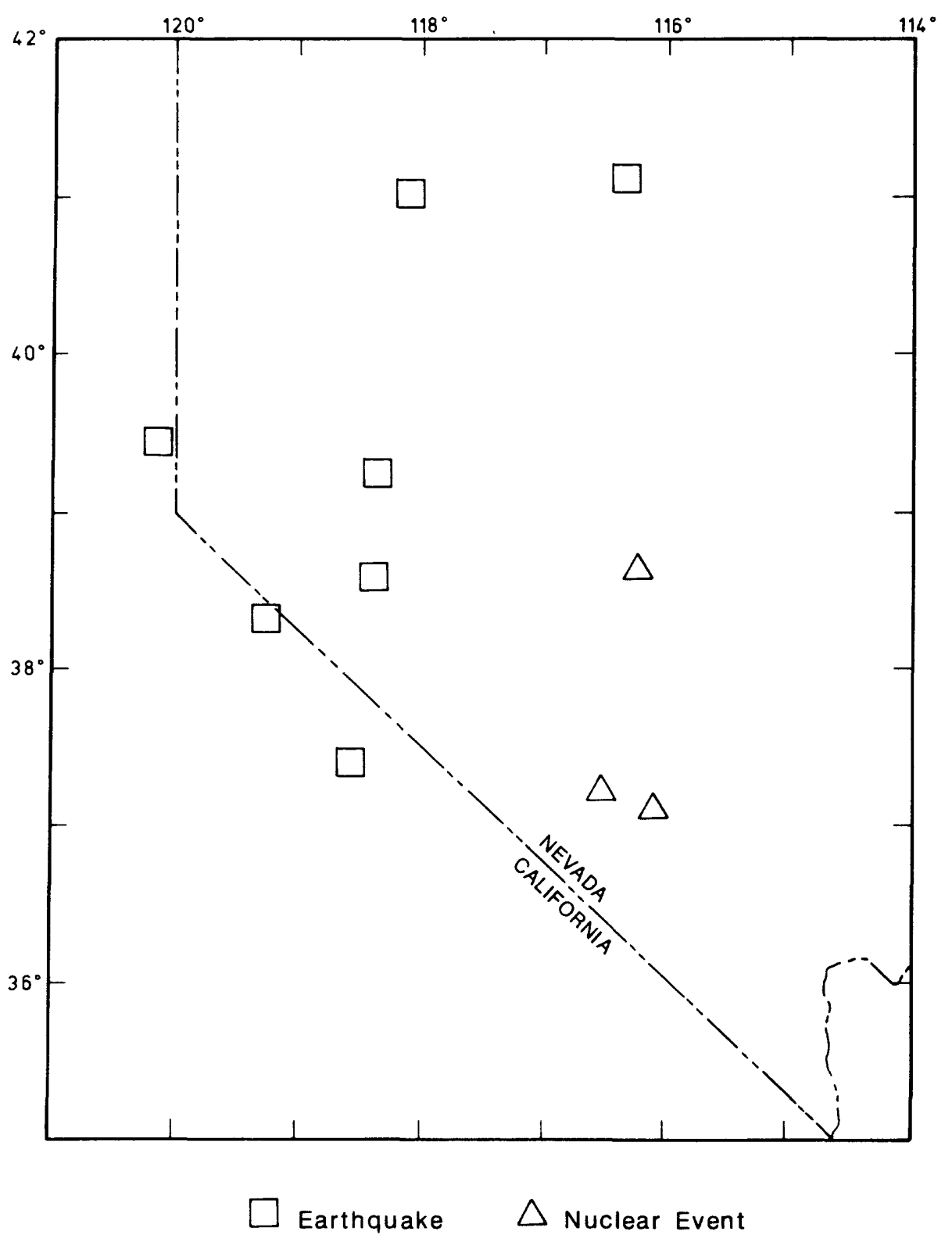

Figure 3.--Locations of the master events used for determining the traveltime curves shown in figure 4. 


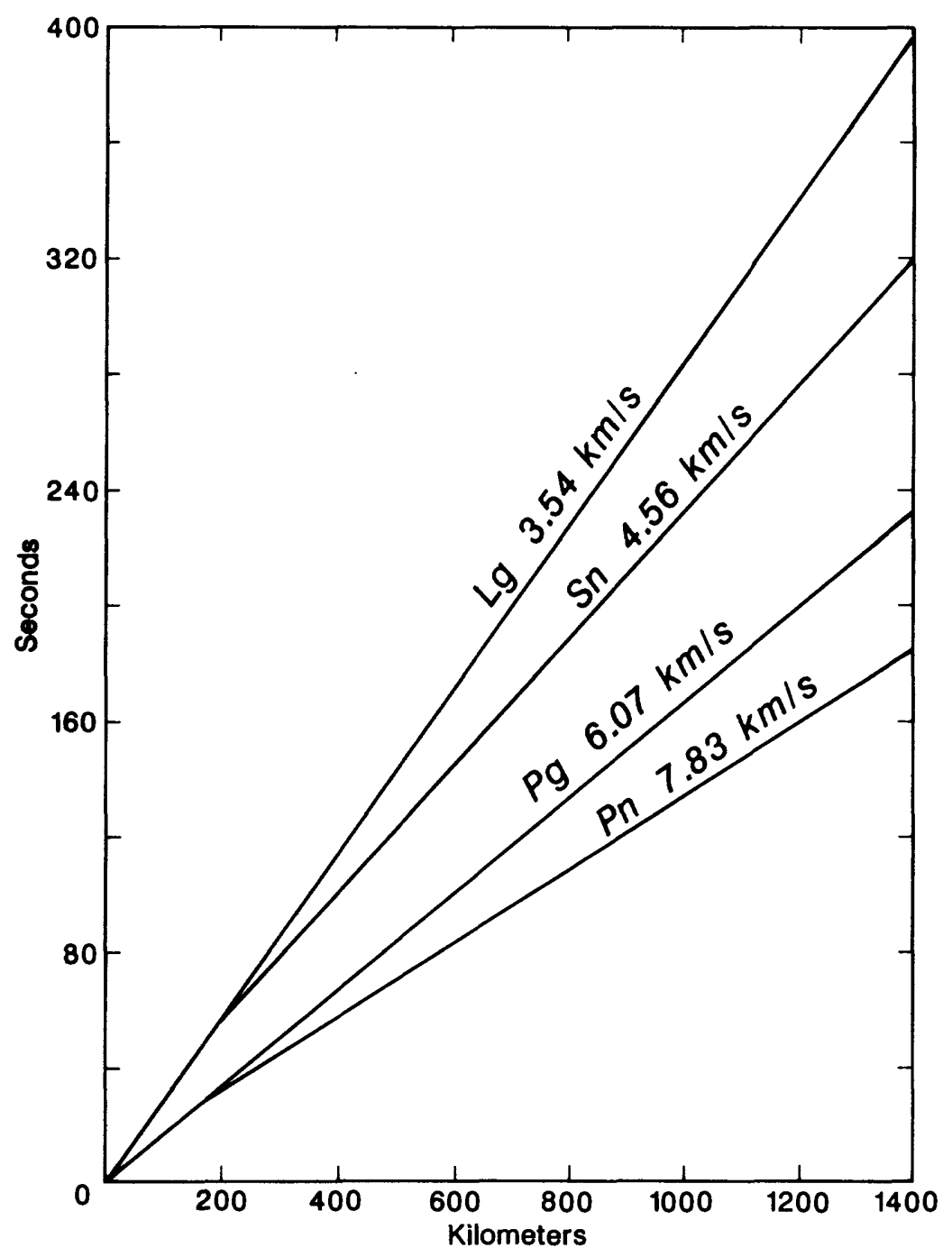

Figure 4.--Traveltime curves of the model used for the relocation of the epicenters in this study. 
$1931-1963$

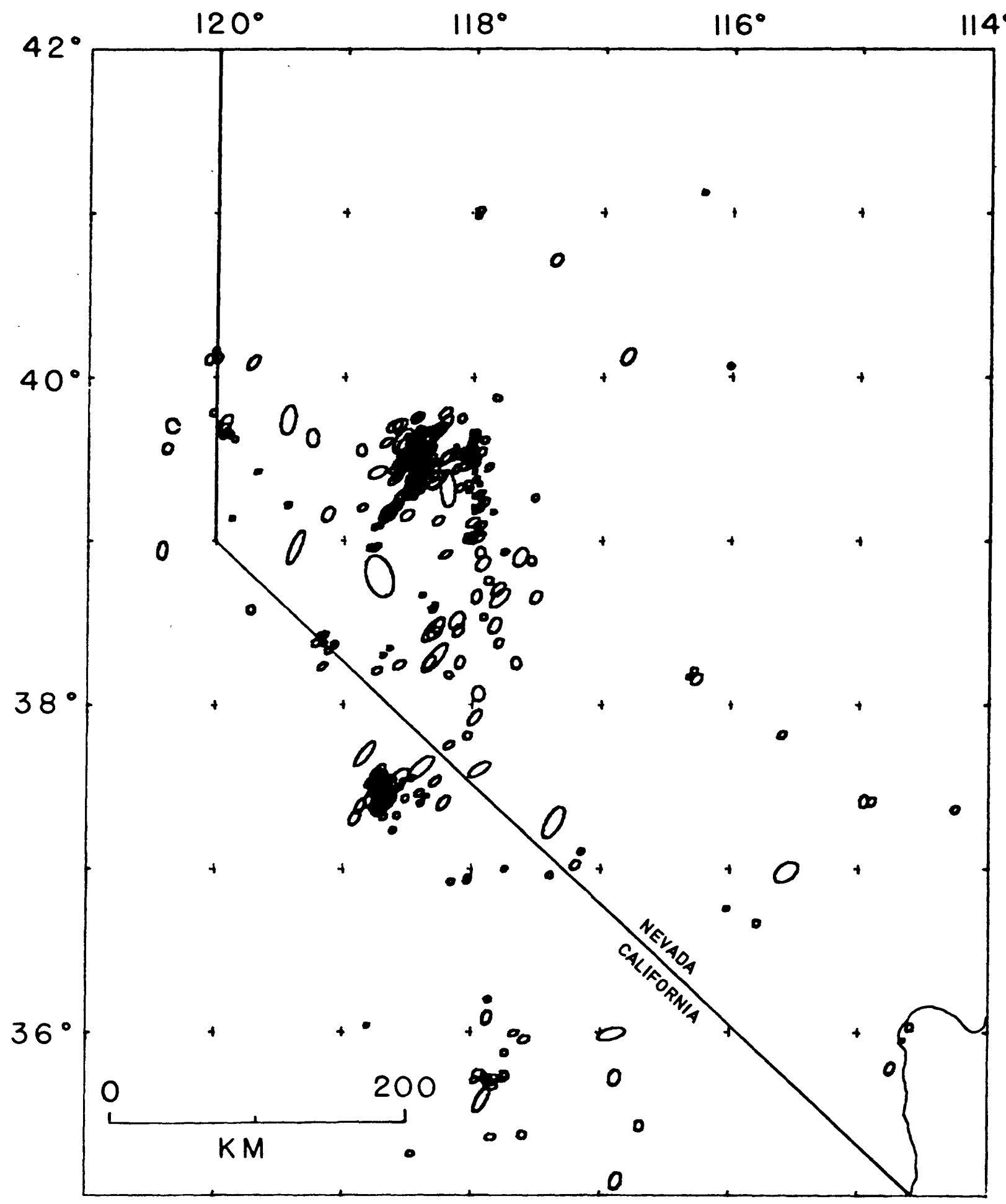

Figure b.--90-percent confidence ellipses for 1931-1963 earthquakes studied. 


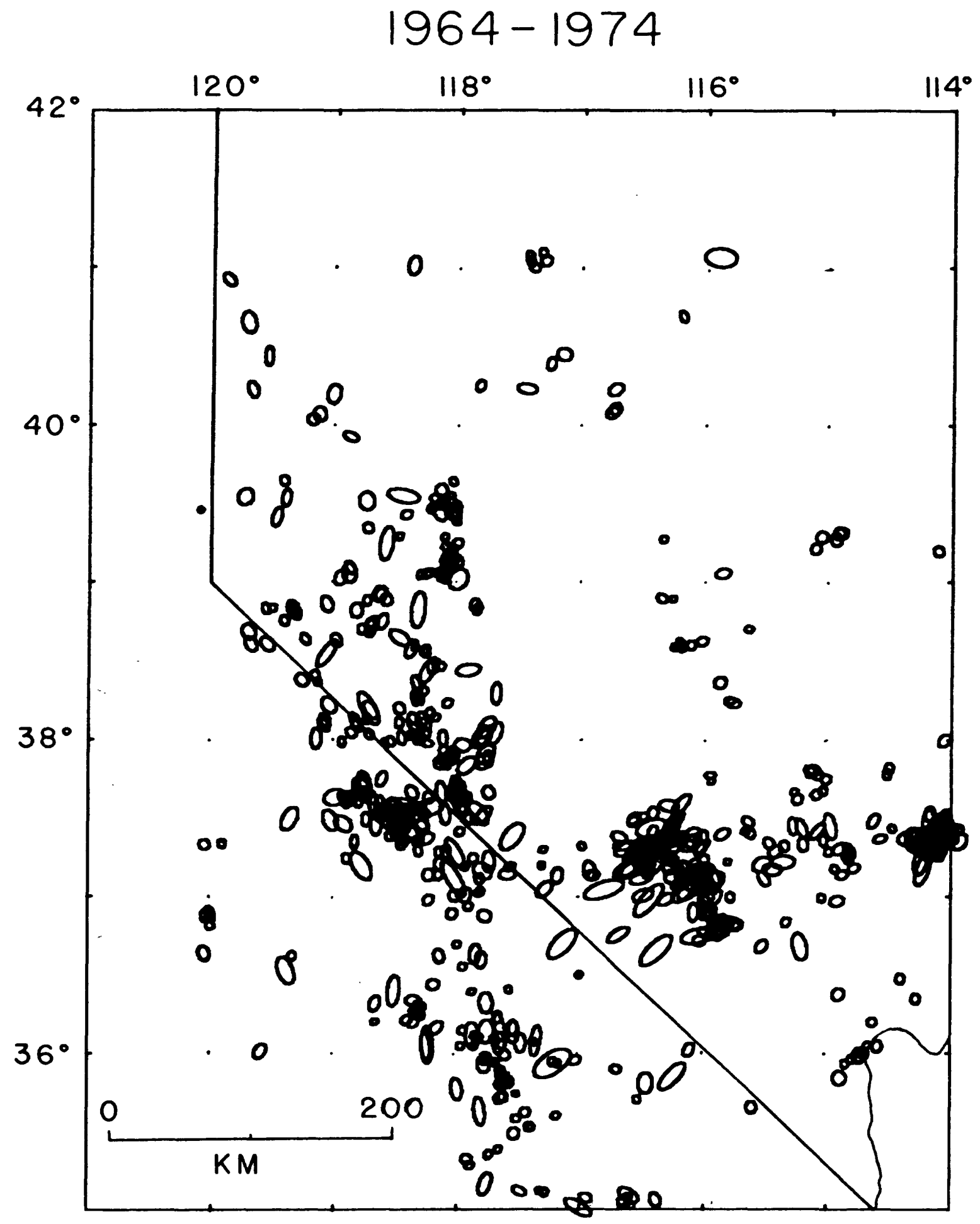

Figure 6.--90-percent confidence ellipses for 1964-1974 earthquakes studied. 


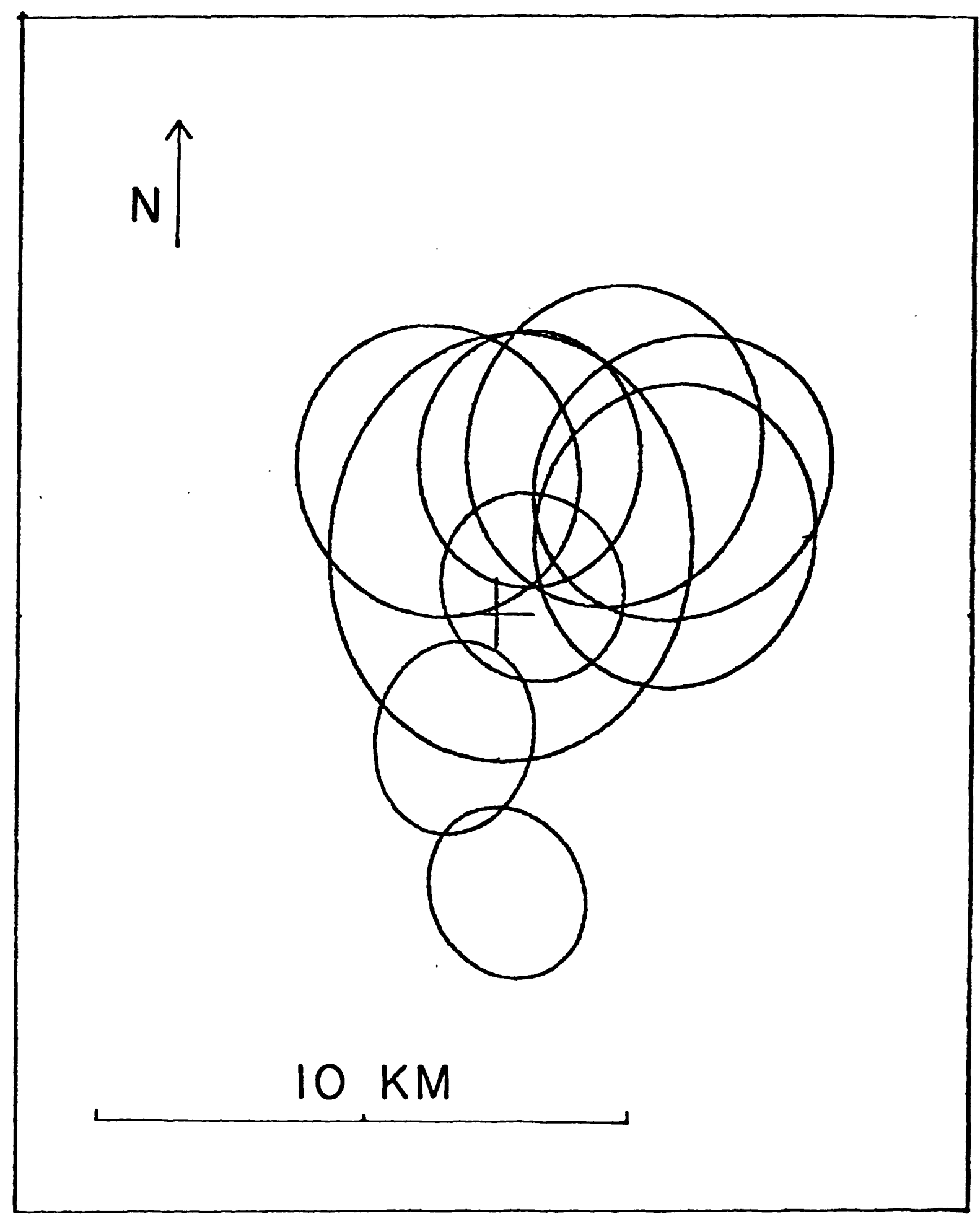

Figure 7.--90-percent confidence ellipses for nuclear explosions with known locations. 


\section{Nuclear Events}

Nine nuclear explosions with precisely known locations were located using the above techniques. Figure 7 shows the confidence ellipses of these events, relative to the actual locations, which have all been shifted to the cross in the center of the diayram. The three smaller ellipses were located using secondary phases, whereas the others were not. This plot indicates the absolute accuracy of the locations using the above techniques, and the small systematic shift to the north of events located without secondary phases. As fewer than 90 percent of the events have ellipses covering the true epicenter, figure 7 also implies that the ellipses may be slightly optimistic, because they do not account for errors in the velocity model.

\section{RESULTS OF EARTHQUAKE RELOCATION}

Relocation has greatly improved overall accuracy in general, and relative accuracy in particular, for larger earthquakes that have occurred throughout much of Nevada since 1930. Comparison of the relocated epicenters relative to those reported by the ISS indicates that many of the epicenters were mislocated by tens of kilometers; a few epicenters were found to be mislocated by more than 100 kilometers. As an example of one of the worst mislocations, see earthquake of $7 / 11 / 42$ (Appendix $B, p, 2$ ); this event was originally located at lat $40.8^{\circ} \mathrm{N}$. and long $117.5^{\circ} \mathrm{W}$. The errors were probably due to (1) epicenters not actually located with data, but assigned a location based on previous events, or (2) epicenters located with incorrect phase arrivals. As a consequence of improvement in epicentral accuracy, several of the mainshock-aftershock sequences of major earthquakes and swarms can now be delineated, and will be discussed in the next section of this report. The east-west seismic zone, which appears to connect the Nevada-California seismic zone with the Intermountain seismic zone in Utah, has been better defined.

\section{INTERPRETATION OF DATA}

The following sections discuss seismicity and larger earthquake sequences in the Fallon-Tonopah and Owens Valley regions of the Nevada-California seismic zone, and in the east-west seismic zone (fig. 1). Several large historic earthquakes have occurred in the Nevada-California seismic zone, but activity in the east-west zone has tended to involve smaller earthquakes occurring at a more uniform rate.

Slip-vector directions given in the following discussion refer to the direction that the south or west side of the fault moved during the earthquake. 


\section{Fallon-Tonopah Region}

During the years 1932-1963 the region lying generally between Fallon and Tonopah (from lat $38^{\circ} \mathrm{N}$. to $40^{\circ} \mathrm{N}$. and long $117^{\circ}$ to $119^{\circ} \mathrm{W}$.) was the most tectonically active and seismologically interesting area in Nevada (fig. 8). Several larye earthquake sequences occurred during this period in this relatively small area (fig. 9). Were these sequences related, and if so, how? Four possibilities are suggested here: (1) the changing strain field of one large earthquake triggered subsequent earthquakes; (2) several large earthquakes occurred independently within a short period of time relative to their recurrence intervals because of a relatively rapid change in the regional stress field; (3) all the earthquakes occurred as independent responses to slowly increasing regional stress; and (4) the recurrence intervals for large earthquakes is shorter than previously suspected.

In this study it is possible to show only some of the apparent coincidences that occurred during these sequences, and to speculate whether significant relationships do exist. Figure 10 shows 90 -percent confidence ellipses for relocated epicenters in the Fallon-Tonopah region. The epicenter has a 90-percent chance of being within the area shown, assuming that all errors are normally distributed, and that the velocity structure is perfectly modeled. Some pertinent information is given below about the individual sequences, the geometry of rupture, and, in some cases, the time histories.

\section{Cedar Mountain Earthquake}

The Cedar Mountain earthquake occurred December 21, 1932, at 6:10:03.6 GMT at about lat $38.83^{\circ} \mathrm{N}$. and long $117.92^{\circ} \mathrm{W}$. with a magnitude of 7.2 . Gianella and Callaghan (1934) reported that the epicentral region, a large alluvial valley, lacked a continuous distinct surface fault rupture; there was, however, a large area of severely disturbed ground, approximately $65 \mathrm{~km}$ by $10 \mathrm{~km}$. This area exhibited both extensional grabens and compressional ridges with dextral strike-slip of as much as a meter. The disturbed region had a strike of about $\mathrm{N} .20^{\circ} \mathrm{W}$., which was interpreted as the approximate average direction of slip in the earthquake (Gianella and Callaghan, 1934).

One foreshock of the Cedar Mountain event was felt about one-half hour before the mainshock. Two large aftershocks were located southeast of the main event (fig. 11); a third event ( $A$, fig. 11 ), here considered to be an aftershock, was located about $100 \mathrm{~km}$ to the south in the vicinity of Columbus Salt Marsh. Another event, possibly an aftershock, occurred 2 hours after the mainshock at a location ( $B$, fig. 11) about $50 \mathrm{~km}$ to the southwest and about 20 $\mathrm{km}$ north of the location of the Excelsior Mountains earthquake, which occurred 2 years later. About 2 months after the Cedar Mountain earthquake, a moderate earthquake occurred very near the future location of the Fairview Peak earthquake of 1954 (fig. 8). 


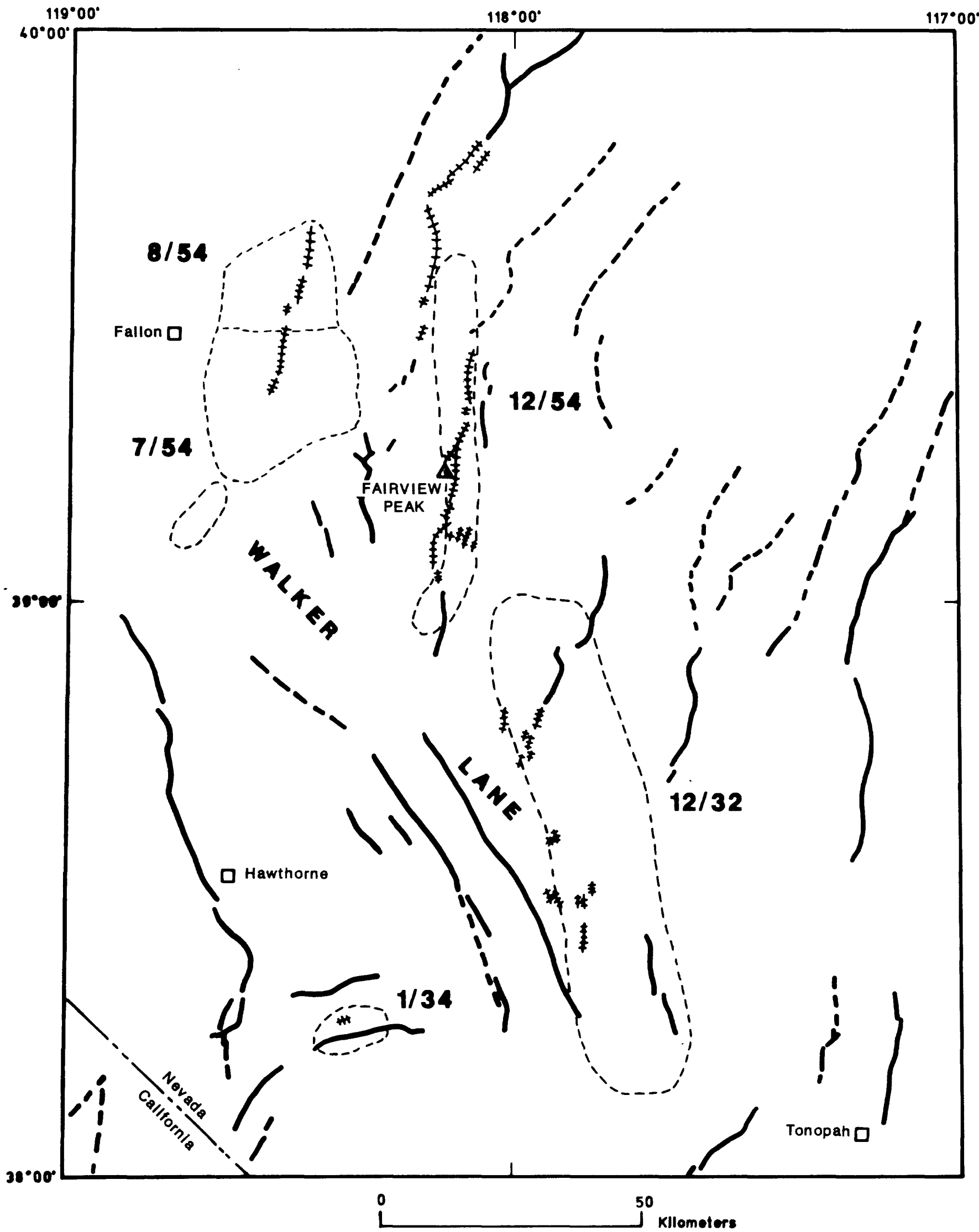

Figure 8.--Fault pattern in the Fallon-Tonopah region showing surface ruptures (hachured lines) and month and year of main events discussed in this report. Dashed lines indicate approximate aftershock zone boundaries. 


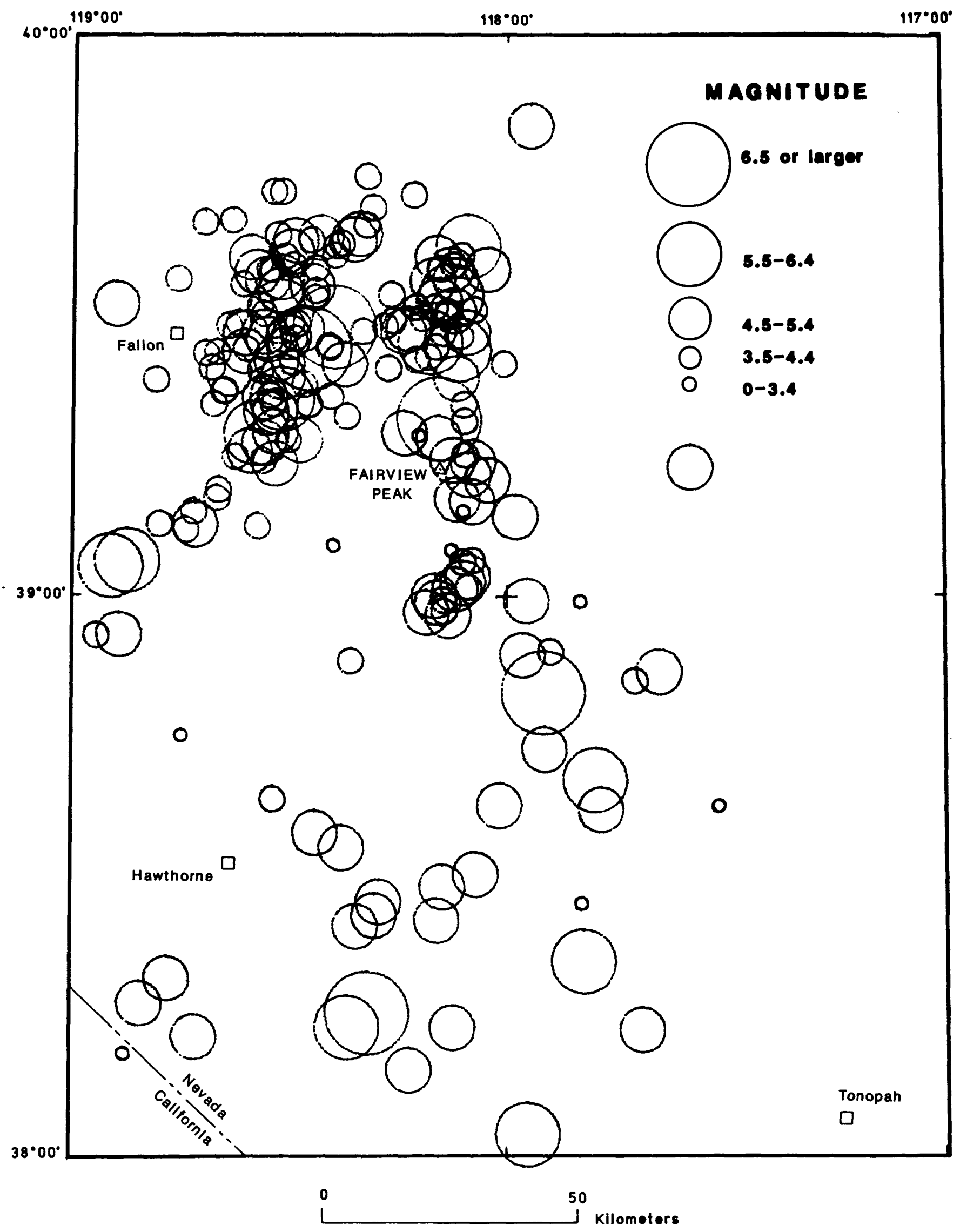

Figure 9.--Relocated 1931-1963 epicenters in Fallon-Tonopah region (magnitudes shown by circle diameter). 


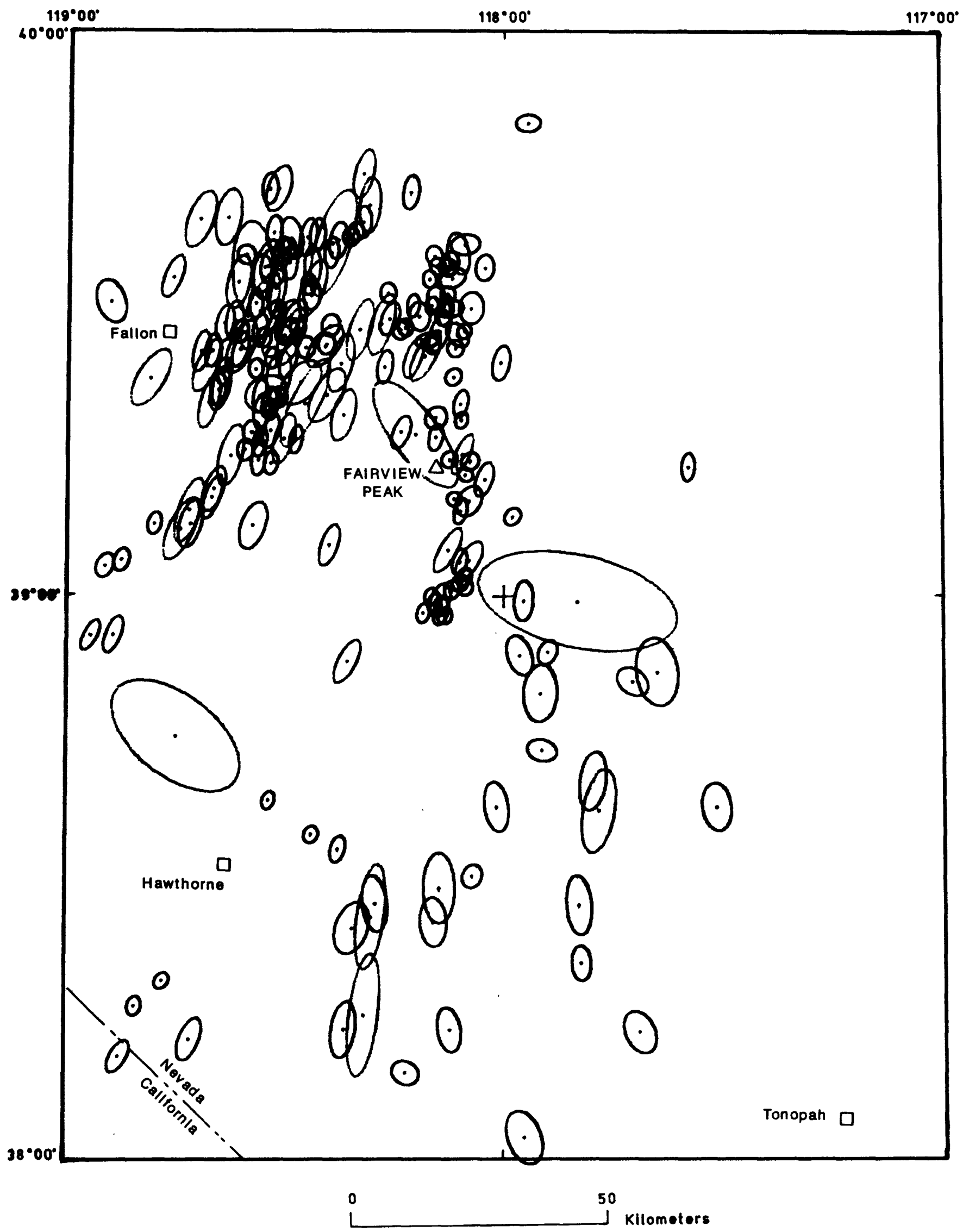

Figure 10.-- 90-percent confidence ellipses for relocated 1931-1963 epicenters in Fallon-Tonopah region. 


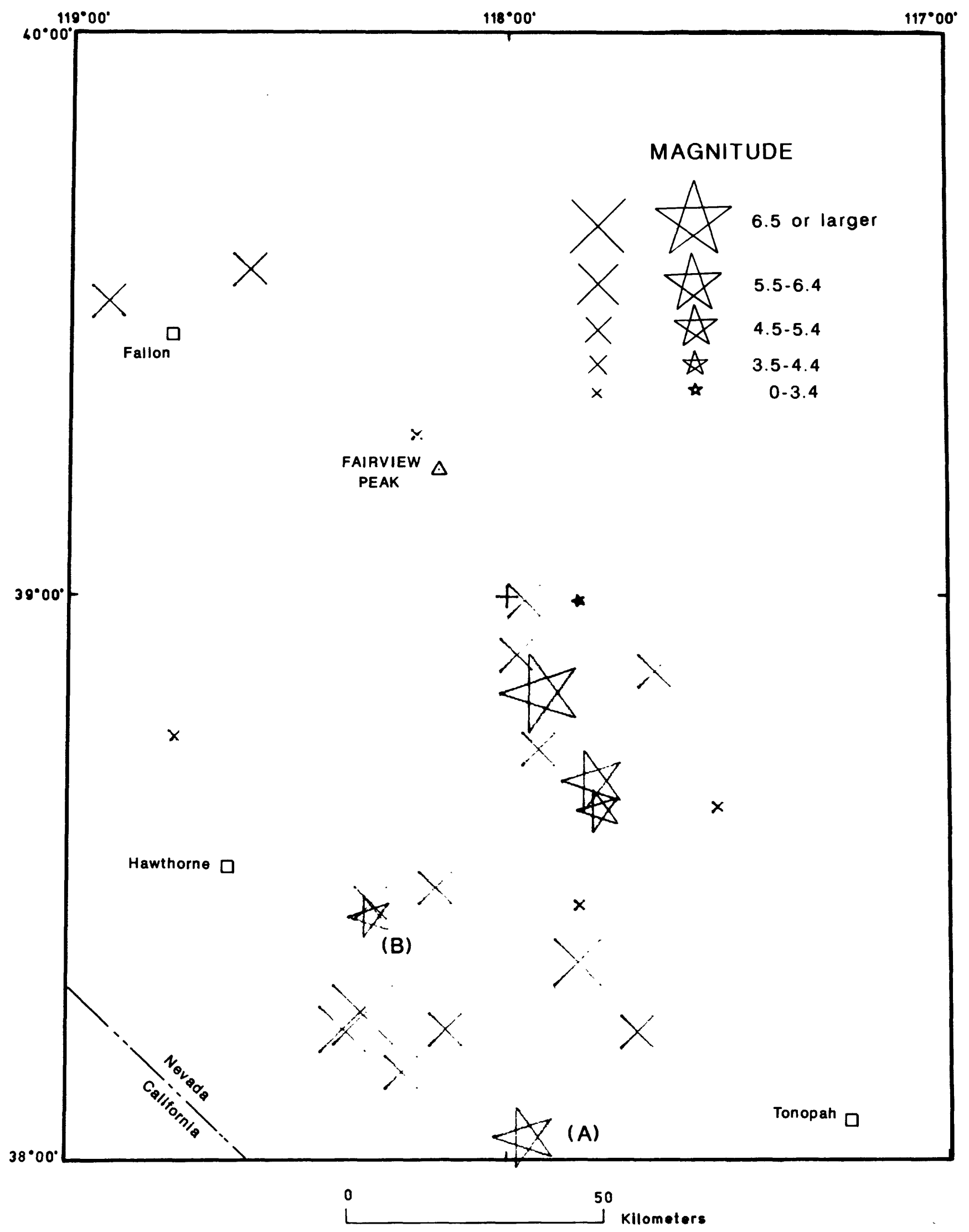

Figure 11.-- Location of the 1932 Cedar Mountain earthquake. (Stars represent the mainshock and first 24 hours of aftershocks large enough to be relocated. $X$ 's are the next 10 years of shocks relocated throughout the region.) 
Byerly (1935) reported short and long period first motion data of the Cedar Mountain earthquake. These data are replotted on figure 12, with higher credence given to the long period data in determining the focal mechanism. The inferred fault plane has a strike of $\mathrm{N} .26^{\circ} \mathrm{W}$. and a dip of $44^{\circ} \mathrm{W}$., and a slip-vector direction of $\mathrm{N} .52^{\circ} \mathrm{W}$. These data suggest slip was predominantly normal with a subordinator strike-slip component. Field evidence of slip from Gianella and Callaghan (1934) is probably better, however, than the focal mechanism, because of inadequacies of the seismograph records.

\section{Excelsior Mountains Earthquake}

The 1934 Excelsior Mountains earthquake $(M=6.3)$ occurred January 30, 1934, at 19:23:52.8 GMT at lat $38.24^{\circ} \mathrm{N}$. and long $118.37^{\circ} \mathrm{W}$. (fig. 8). Callaghan and Gianella (1935) discovered a small surface rupture in bedrock about $7 \mathrm{~km}$ northeast of the epicentral location. They reported the break as slightly over a kilometer long, striking about N. $65^{\circ} \mathrm{E}$. Maximum movement was reported as $0.13 \mathrm{~m}$ dip slip with the north side down. Examination of the surface breakage by the second author in 1973 indicated a length of about 1.7 $\mathrm{km}$ and maximum scarp height of $0.45 \mathrm{~m}$.

Unly one aftershock of this earthquake was well located (fig. 13) and no aftershock trend was determined. Three foreshocks were reportedly felt during the preceding day or so. Ryall and Priestley (1975) published a composite focal mechanism of more recent earthquakes in the Excelsior Mountains region showing normal faulting with nodal planes striking N. $3^{\circ} \mathrm{W}$. and N. $49^{\circ} \mathrm{E}$., dipping $50^{\circ} \mathrm{E}$. and $54^{\circ} \mathrm{NW}$., respectively. As the surface break and most other faults in the area strike east-northeast, the northeast plane is favored. Assuming a similarity of more recent earthquake focal mechanisms with the 1934 event, the slip-vector of the 1934 event was probably oriented nearly horizontally in a $\mathrm{N} .87^{\circ} \mathrm{E}$. direction.

\section{Fallon-Stillwater (Rainbow Mountain) Sequence}

Two large earthquakes, both with magnitudes of 6.8 , occurred on July 6 , 1954 at 11:13:18.7 GMT, and on August 24, 1954, at 5:51:30.9 GMT, with locations at lat $39.45^{\circ} \mathrm{N}$. and long $118.46^{\circ} \mathrm{W}$. and $39.48^{\circ} \mathrm{N}$. and $118.40^{\circ} \mathrm{W}$., respectively (fig. 8). Tocher (1956) investigated the field region after each of the earthquakes, and reported a surface rupture in unconsolidated material associated with the Rainbow Mountain fault, which was $18 \mathrm{~km}$ in length after the July event, and extended northward an additional $22 \mathrm{~km}$ after the August event. The fault had a strike of $\mathrm{N} .15^{\circ} \mathrm{E}$. in the region of the July rupture, changing to N. $20^{\circ} \mathrm{E}$. in the region of the August rupture. The second rupture exhibited purely vertical movement (west side up) with slip of about $0.3 \mathrm{~m}$ in the south to a maximum of $0.75 \mathrm{~m}$ in the northern region. Geodetic measurements taken just before the earthquake and repeated the following year (Whitten, 1957) indicated about $1 \mathrm{~m}$ of dextral slip on a benchmark near Stillwater relative to Fallon (fig. 14). 


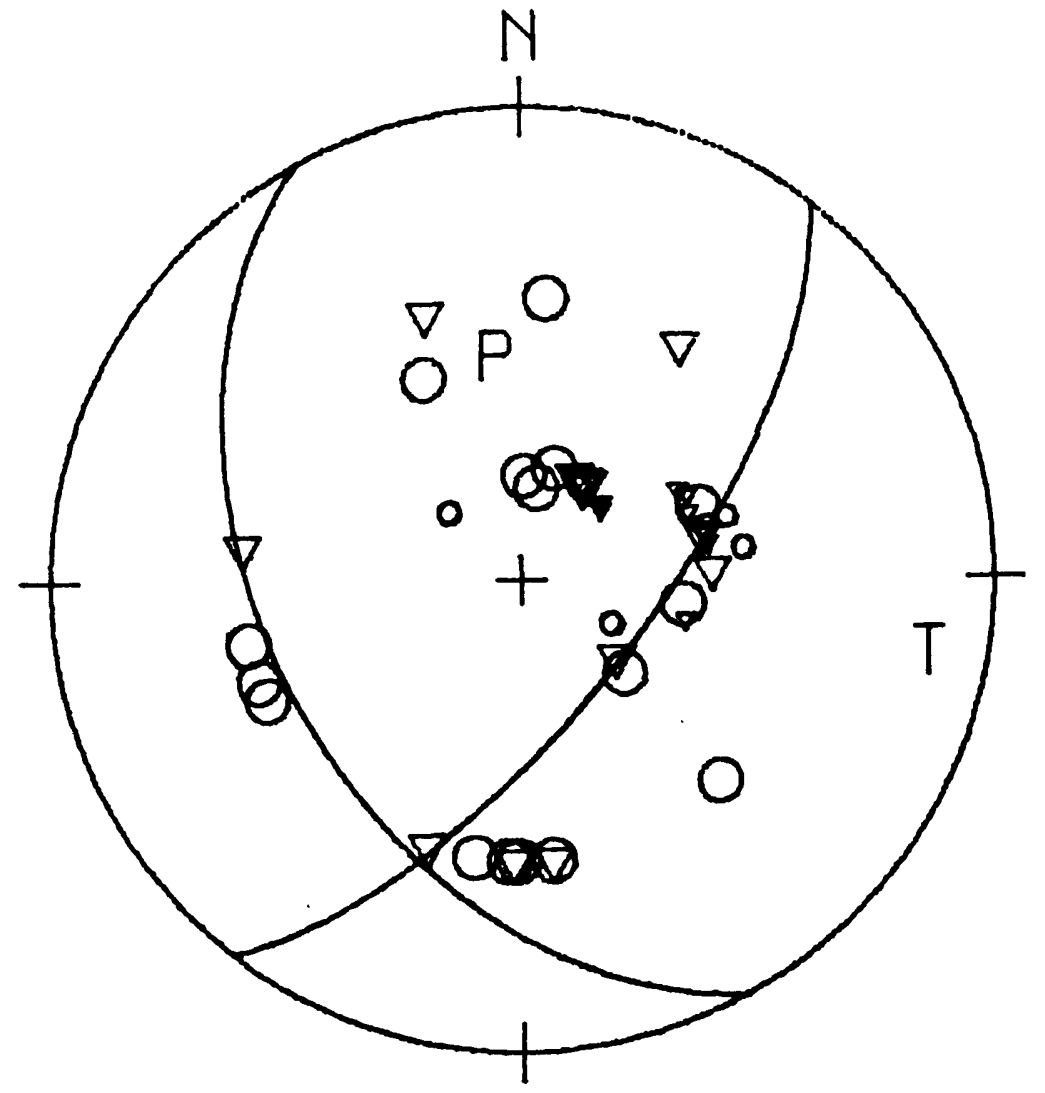

Figure 12.-- Focal mechanism plot for the 1932 Cedar Mountain earthquake. (Circles are compressions, triangles are dilatations; the larger symbols represent data points considered more reliable. Ppressure axis; T-tension axis.) 


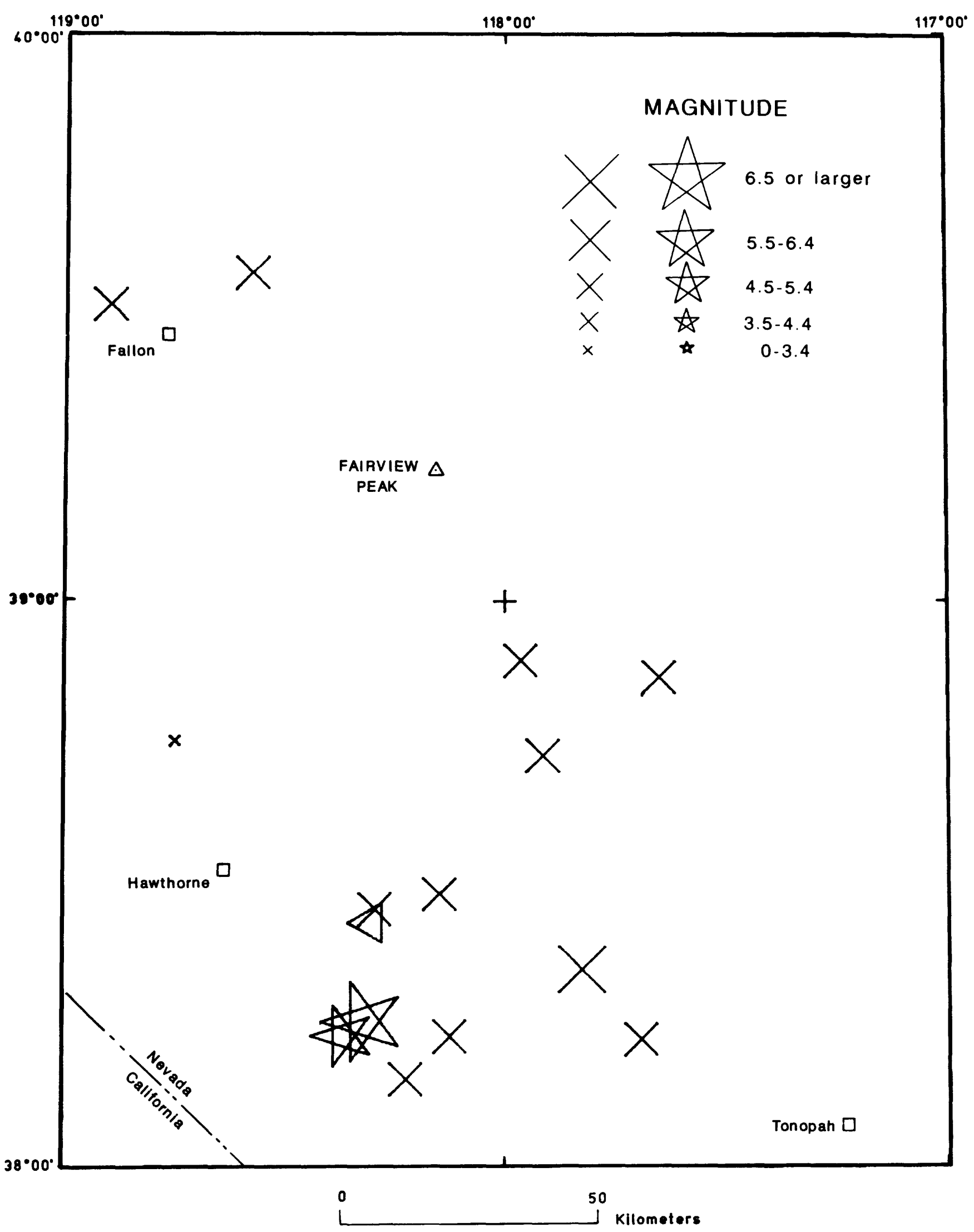

Figure 13.-- 1934 Excelsior Mountains earthquake. (Triangle represents a possible foreshock that occurred a few hours after the 1932 Cedar Mountain earthquake. Stars represent the mainshock and the only relocatable aftershock occurring within 24 hours of the mainshock. $X ' s$ are the next 10 years of earthquakes.) 


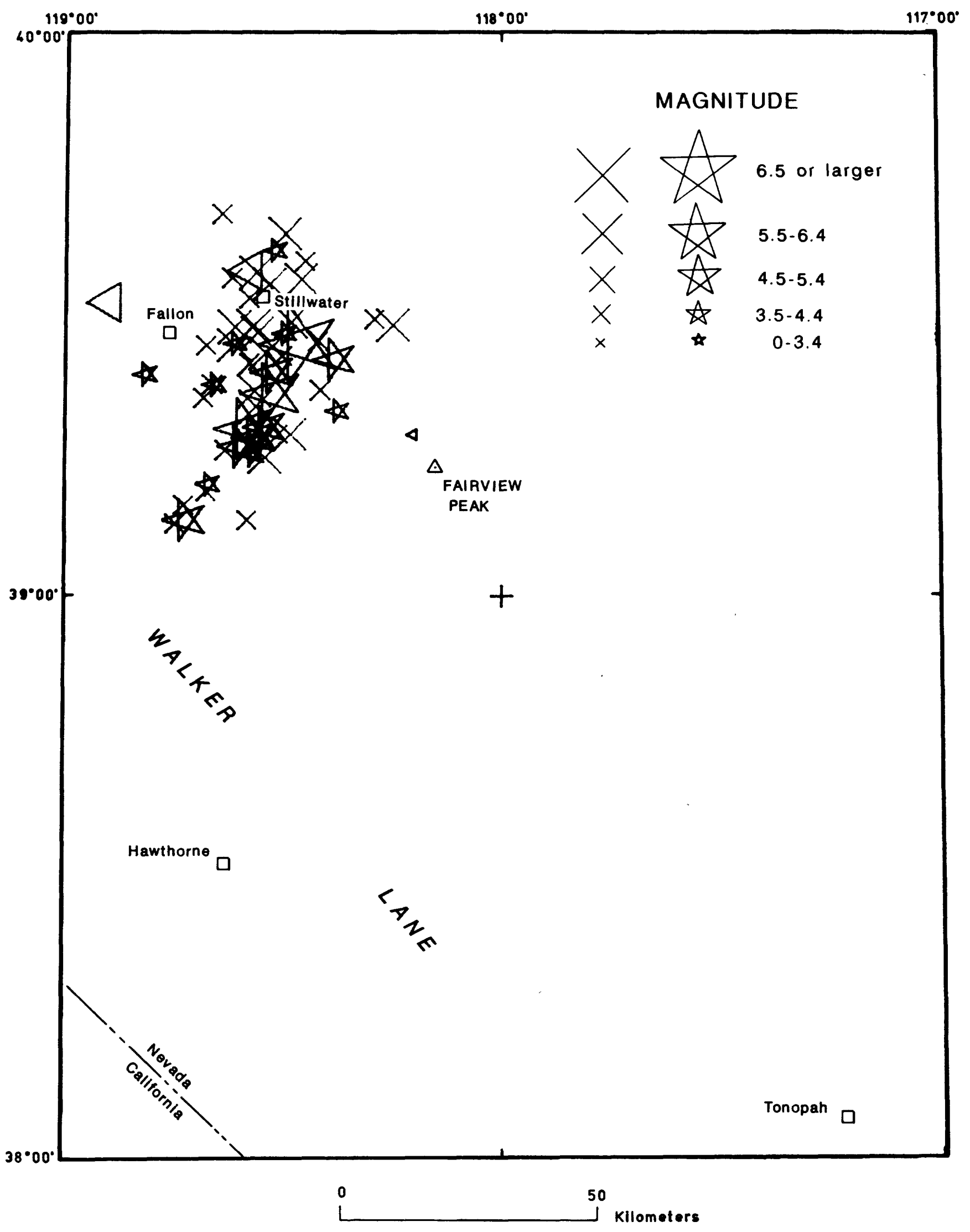

Figure 14.-- July 1954 Fallon-Stillwater earthquake. (Triangles represent earthquakes occurring in 1933 and 1941. Stars are the mainshock and the first 24 hours of aftershocks. X's are aftershocks up to August 24, 1954, the date of the next large event in the area.) 
Aftershocks of the July earthquake indicate a unilateral rupture about 25 $\mathrm{km}$ long trending about $\mathrm{S} .5^{\circ} \mathrm{W}$. from about lat $39.5^{\circ} \mathrm{N}$. to the vicinity of the Walker Lane (fig. 14). Several aftershocks occurred to the southwest of the southern end of the primary aftershock zone. Many other events were located north of the mainshock in the vicinity of the August 1954 earthquake rupture. Two aftershocks occurred near the Fairview Peak fault (fig. 8) which ruptured $b$ months later.

The seismicity following the earthquake of August 24 (fig. 15), was more dispersed than that from the previous earthquake, with no obvious trend (fig. 15). This dispersion may be due solely to location errors, or perhaps, considering the lack of dispersion of the Fairview Peak aftershock zone, a real scattering of aftershocks occurring on several faults. One aftershock on August $31 \quad(M=5.8)$ was located in Dixie Valley about $30 \mathrm{~km}$ to the east (fig. 15). This earthquake occurred within the aftershock zone of the subsequent Fairview Peak earthquake, and was reported to have caused cracks in alluvium of Dixie Valley.

A composite focal mechanism of the two Fallon-Stillwater mainshocks of July and August 1954, plotted on figure 17, is consistent with a plane of rupture striking N. $15^{\circ} \mathrm{E}$. and dipping $50^{\circ} \mathrm{E}$. The slip-vector strikes $\mathrm{N} .15^{\circ}$ W.; however, differences in teleseismic first motions reported in the ISS for stations near the center of the focal sphere suggest the mechanisms of the two mainshocks may differ slightly.

\section{Fairview Peak Earthquake}

On December 16, 1954, at 11:07:11.7 GMT, a magnitude 7.2 earthquake located at lat $39.32^{\circ} \mathrm{N}$. and long $118.16^{\circ} \mathrm{W}$. ruptured faults in the Fairview Peak area and Dixie Valley (figs. 8 and 16). Large scarps were formed in an area nearly $100 \mathrm{~km}$ long by $30 \mathrm{~km}$ wide. Displacements of 2 to $6 \mathrm{~m}$ occurred in Dixie Valley, and 2 to $4 \mathrm{~m}$ along the Fairview Peak fault zone (Slemmons, 1957). The Dixie Valley fault exhibited little strike-slip motion; the few observations of strike-slip were inconsistent in sense of displacement. The Fairview Peak fault, however, had large dextral strike-slip motion, typically about $4 \mathrm{~m}$, which was about twice the magnitude of the dip-slip component throughout this region (Slemmons, 1957). The dip of the Fairview Peak fault in bedrock ranged from $55^{\circ}$ to $75^{\circ}$ to the east. Geodetic measurements taken just before the earthquake and repeated shortly after (Whitten, 1957) were found to fit quite well a simple rectangular dislocation surface along the Fairview Peak fault zone (Savage and Hastie, 1969). This model dislocation surface had a length of about $50 \mathrm{~km}$, a strike of $\mathrm{N} .9^{\circ} \mathrm{E}$, a dip of $57^{\circ} \mathrm{E}$., and had dip-slip and strike-slip components of $2.3 \mathrm{~m}$ and $2.9 \mathrm{~m}$, respectively.

Aftershocks of this earthquake were located in a linear north-trending zone centered on the Fairview Peak fault zone (figs. 8 and 16). The location of the mainshock in the center of the aftershock zone suggests bilateral rupture about $70 \mathrm{~km}$ long. No aftershocks were located in the southern $20 \mathrm{~km}$ of the zone until 6 days after the mainshock, suggesting that this section did not rupture in the mainshock. Only a few aftershocks were located near the Dixie Valley fault. 


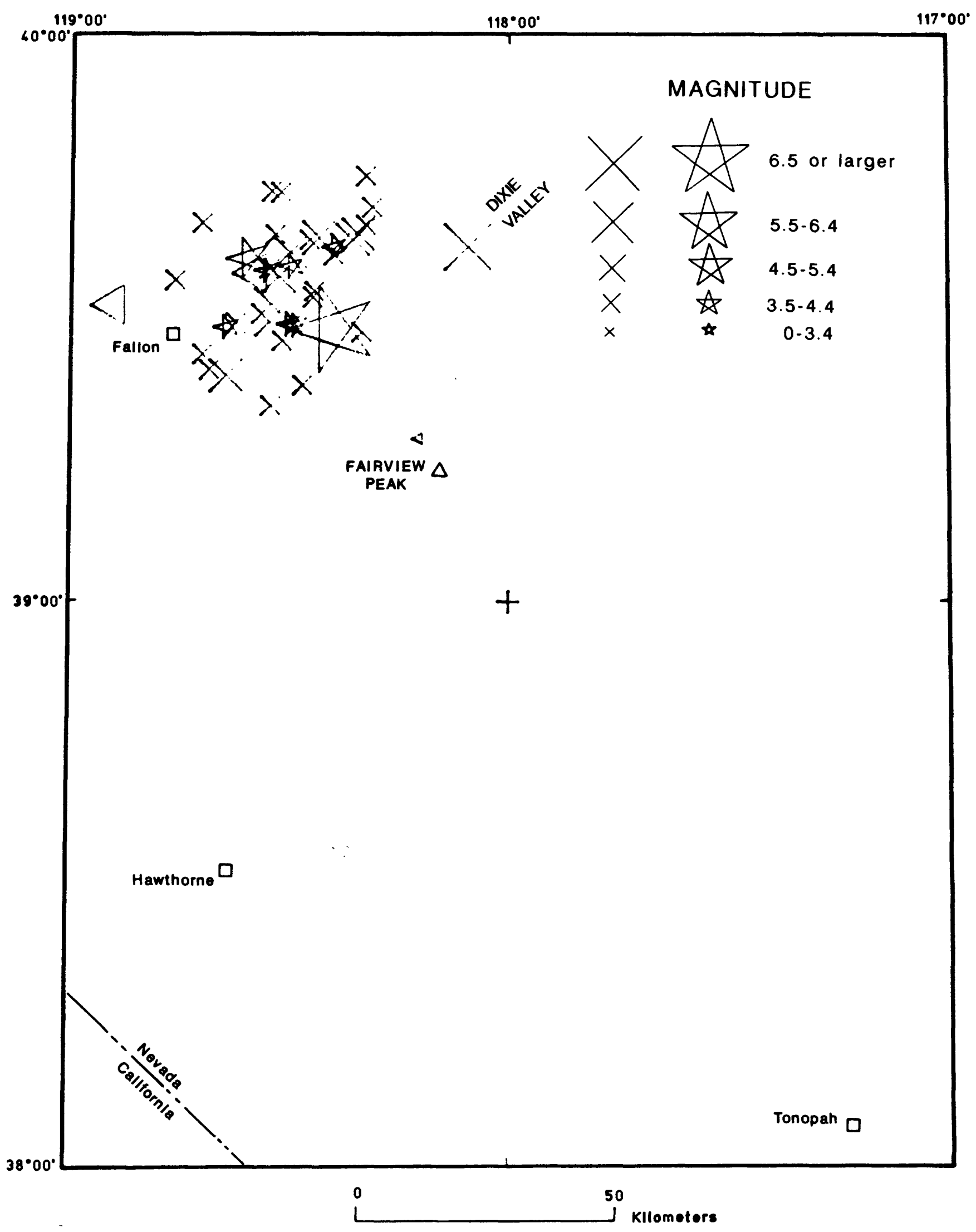

Figure 15.-- August 1954 Fallon-Stillwater earthquake. (Triangles represent earthquakes occurring in 1933 and 1941. Stars are the mainshock and first 24 hours of aftershocks. X's are aftershocks through December 15, 1954.) 


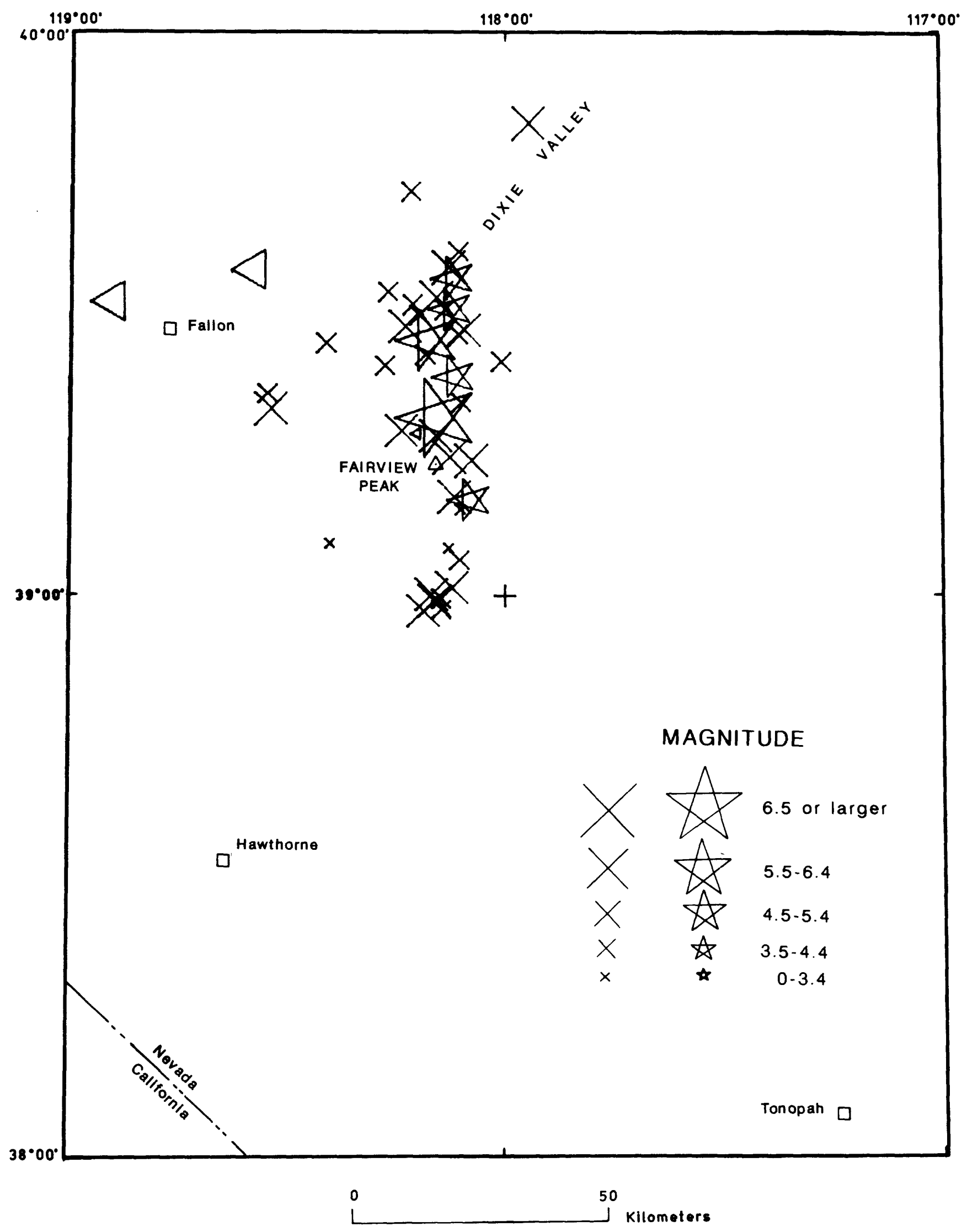

Figure 16.-- 1954 Fairview Peak earthquake. (Triangles represent earthquakes occurring in 1933 and 1941. Stars are the mainshock and first 24 hours of aftershocks. $X$ 's are the next 6 months of aftershocks.) 


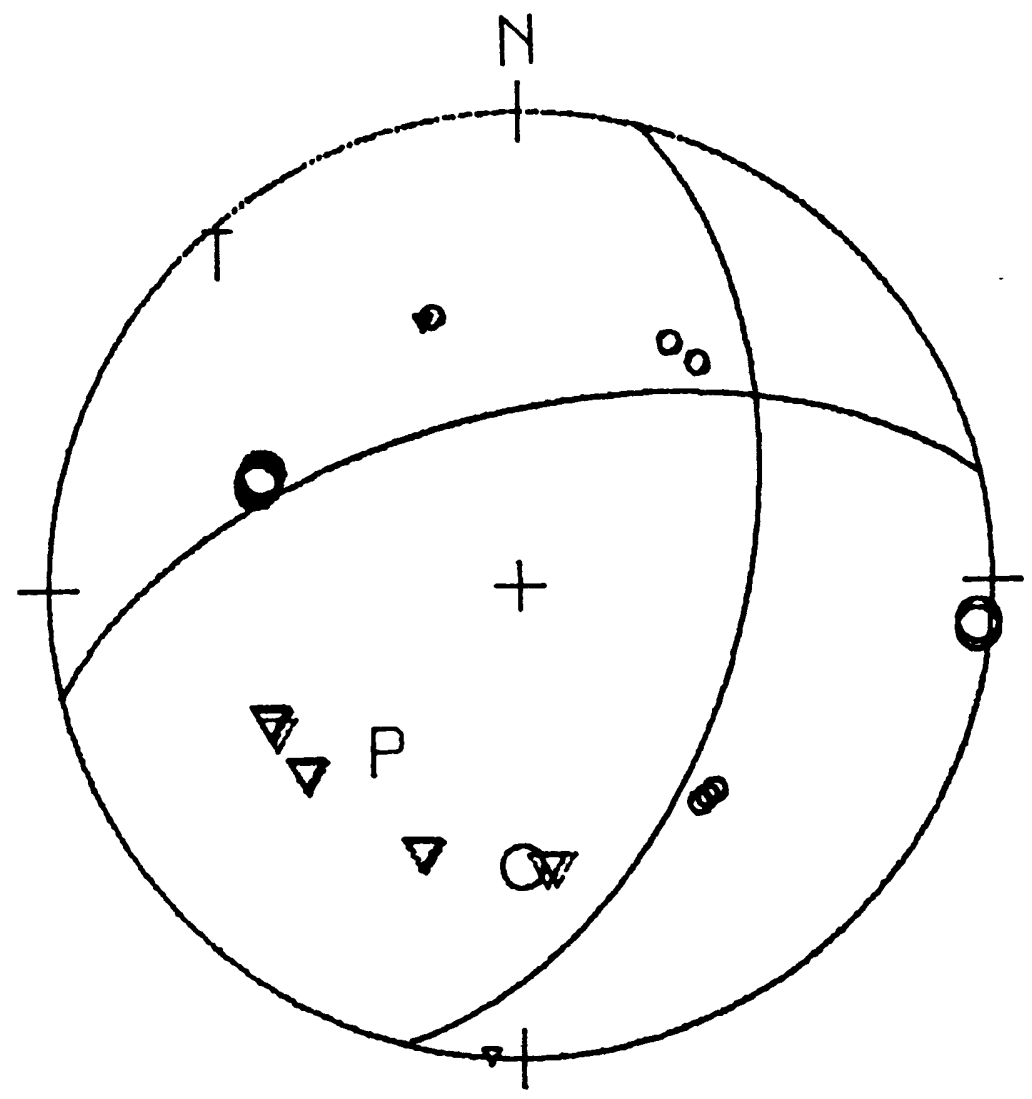

Figure 17.-- Focal mechanism plot for the 1954 Fallon-Stillwater (Rainbow Mountain) composite. (Circles are compressions, triangles are dilitations; the larger symbols represent data points considered more reliable. P-pressure axis; T-tension axis.) 
A large aftershock $(M=6.8) 4$ minutes after the Fairview Peak mainshock was originally determined to be located near the Dixie Valley fault zone at 40 $\mathrm{km}$ depth (Romney, 1957). Using P-wave arrival-time data from the ISS bulletin, we relocated the event using a master event technique relative to the mainshock with depths fixed at $8 \mathrm{~km}$. All first arrivals were in the coda of the mainshock, so most regional stations did not report readings for this event, and many of the teleseismic stations had large errors of as much as tens of seconds. Using a Jeffreys' weighting function and an assumed normally distributed reading error of 1.0 second for correctly identified arrivals, a location for this shock was determined to be at lat $39.50^{\circ} \mathrm{N}$., long $118.08^{\circ}$ W., near the northern end of the main aftershock zone. If this location is correct, this aftershock was probably not caused by rupture of the Dixie valley fault, as previously suspected.

Romney (1957) read and published first motion data for the Fairview Peak mainshock. These data and a slightly different interpretation of the nodal planes are shown in figure 18. The fault plane strikes N. $6^{\circ} \mathrm{W}$. and dips $56^{\circ}$ to the east, with a slip-vector trending $\mathrm{N} .27^{\circ} \mathrm{W}$., corresponding to a component of strike-slip about twice the dip-slip. The length of this slipvector is about $2.5 \mathrm{~m}$, as determined from the average slip versus magnitude relationship. This mechanism is similar to one Ryall and Malone (1971) determined by using a composite of recent aftershocks in the central zone of the Fairview Peak fault. They found mechanisms similar in trend to those of Romney, but with more dip-slip at the ends of the rupture, resulting in different plunges for the slip-vectors.

Most of the data for this earthquake are consistent with Savage and Hastie's (1969) model of a simple dislocation surface along the Fairview Peak fault as the source of the earthquake. The near absence of aftershocks near the northern part of the Dixie Valley fault, both in this study and in Ryall and Malone's study (1971), the lack of a significant strike-slip component of slip on the surface fault trace, and the location of the large aftershock 4 minutes after the mainshock south of the main rupture of the Dixie Valley fault suggest that the scarps in Dixie Valley were secondary features resulting from the shaking associated with rupture of the Fairview Peak fault. This is also suggested by Richter (1958, p. 514).

\section{Sequence}

In 1959 an interesting sequence of earthquakes occurred in the same region as the 1954 earthquakes (fig. 19). The sequence started on March 23 with a magnitude 6.3 earthquake and some aftershocks at the northern end of the 1954 Fairview Peak earthquake aftershock zone. On June 23, a small foreshock ( $M=4.4)$ was followed by a magnitude 6.1 earthquake on a possible extension of the southwest-trending rupture zone of the July 1954 FallonStillwater sequence discussed earlier. One-half hour after the $M=6.1$ shock, a small (M=3.9) earthquake ( $A$, fig. 19) occurred about halfway between the two large shocks of this series. Aftershocks continued near both mainshocks. The 1959 sequence appears to have had a northeast-southwest linear trend which passes through and parallels part of the southwest zone of the July 1954 sequence. This sequence was similar to the July through December 1954 FallonStillwater sequence in that activity in the Fairview Peak and FallonStillwater areas was apparently interdependent, implying the same underlying stress mechanism. Unfortunately, insufficient first motion data were available to obtain focal mechanisms of these later earthquakes. 


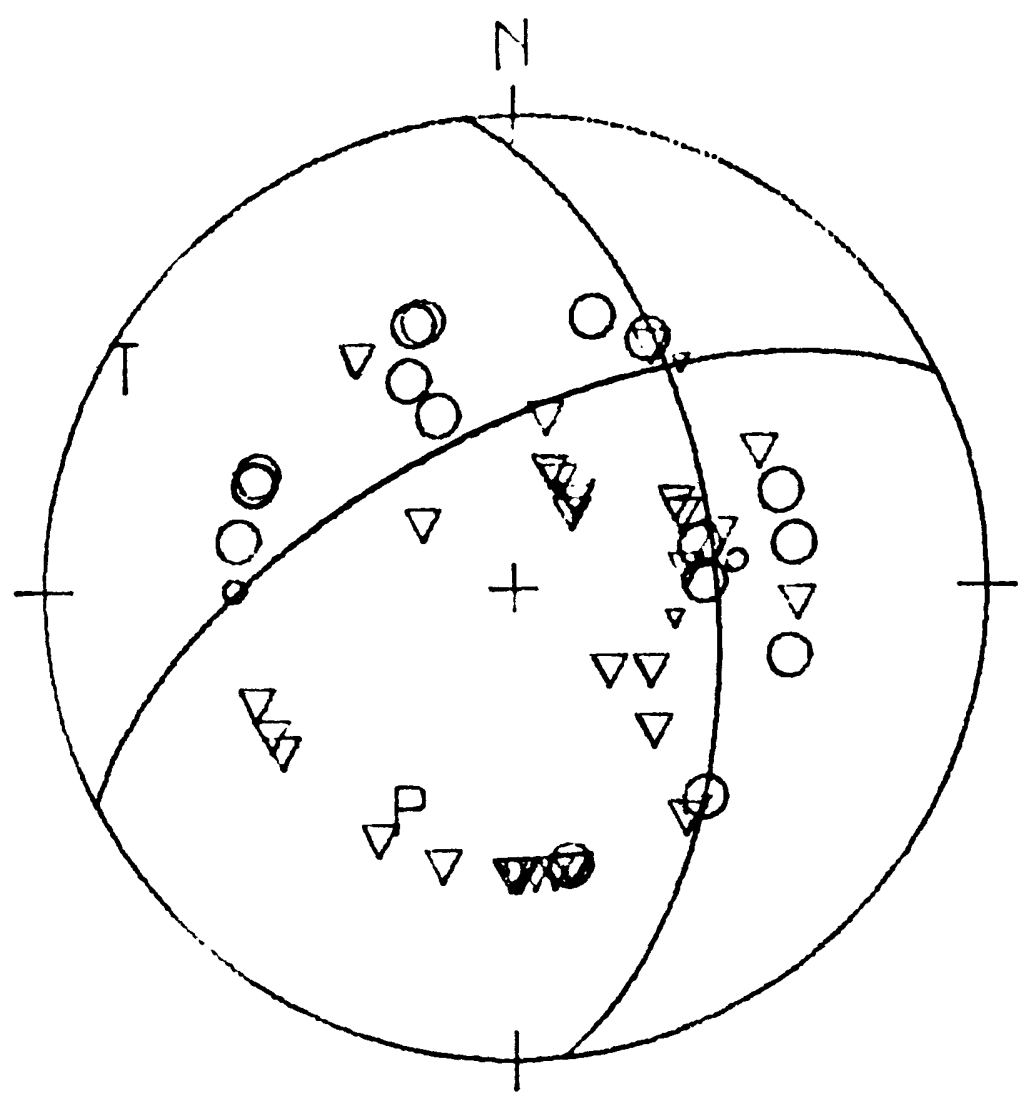

Figure 18.-- Focal mechanism plot for the 1954 Fairview Peak earthquake. (Circles are compressions, triangles are dilatations; the larger symbols represent data points considered more reliable. $\mathrm{P}$ pressure axis; T-tension axis.) 


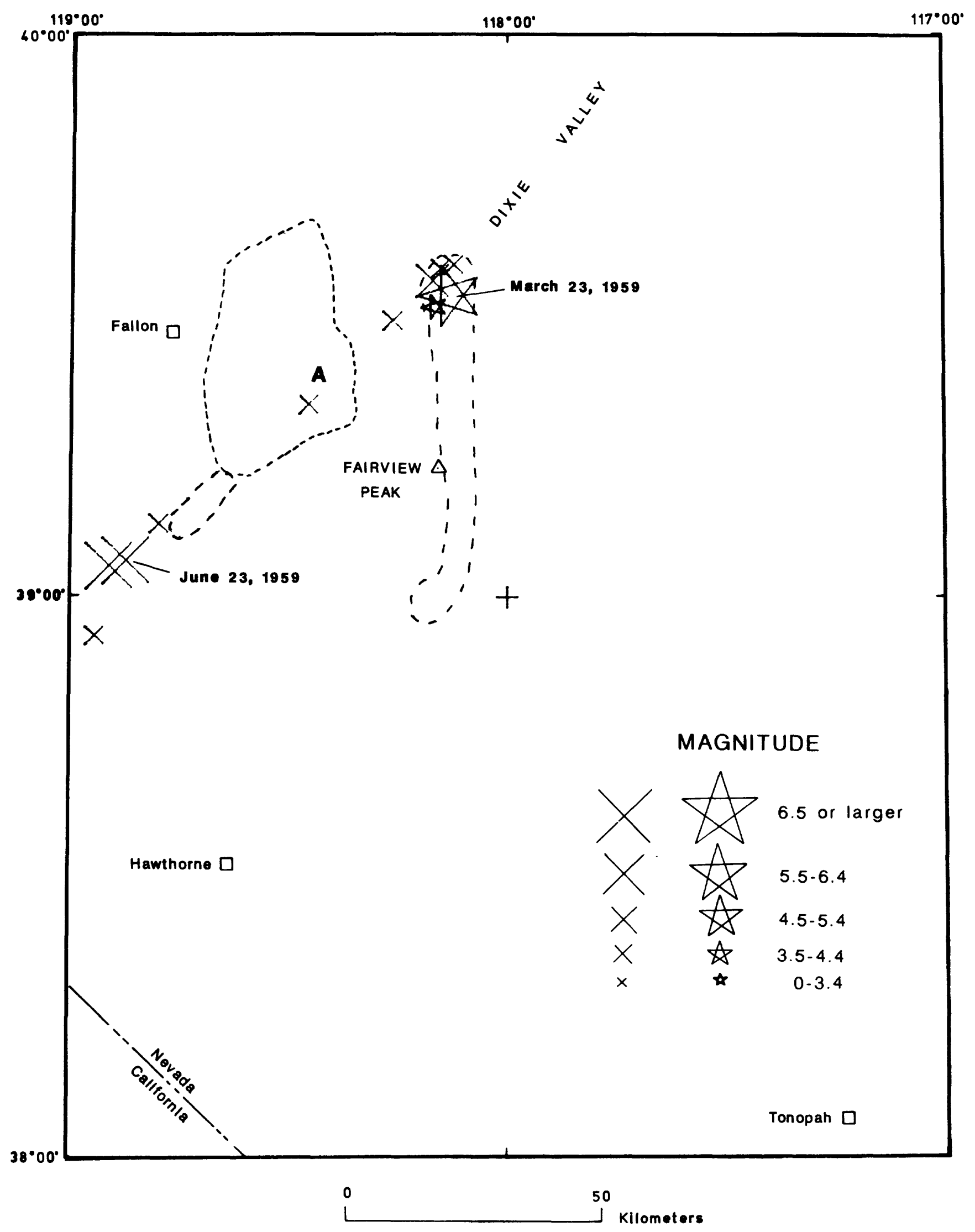

Figure 19.-- 1959 earthquake sequence. (Stars represent March 23 mainshock and first 24 hours of aftershocks. $X$ 's are next 6 months of shocks, including the mainshock of June 23 (mag. $=6.1$ ). Dashed lines enclose the aftershock zones of the three 1954 earthquake sequences (figs. 14, 15, and 16). 


\section{Owens Valley Region}

Owens Valley lies at the foot of the Sierra Nevada within the NevadaCalifornia seismic zone (fig. 1). Most of this region (fig. 20) has not been as active as the Fallon-Tonopah region during the last 50 years, but it was the site in 1872 of the great Owens Valley earthquake, which was felt over a larger region than any other earthquake in the western United States. Although earthquakes have been distributed throughout this region (fig. 21), one area northwest of Bishop, California, has been particularly active, including several magnitude 5-6 earthquakes between 1931 and 1974 . Figure 22 shows 90-percent confidence ellipses for epicenters shown on figure 21 .

\section{Owens Valley Earthquake}

No seismographs were in operation at the time of the 1872 Owens Valley earthquake, so most of what we know is from field observations after the earthquake. Bateman (1961) gave one of the most complete evaluations of the earthquake and concluded that it involved significant components of both dipslip and dextral strike-slip along the Owens Valley fault zone (fig. 20). The main surface rupture occurred in a narrow zone from Owens Lake $\mathrm{N}$. $18^{\circ} \mathrm{W}$. to Big Pine, a distance of about $75 \mathrm{~km}$. The scarps faced both east and west. Near Lone Pine, where the highest $(7 \mathrm{~m})$ vertical scarp (east-facing) was observed, an antithetic west-facing scarp had dextral strike-slip displacements of 3 and $5 \mathrm{~m}$ observed in two different places. As secondary faulting due to gravity slumping has no significant strike-slip component, this west facing scarp was probably part of the primary rupture causing the earthquake.

Composite focal mechanisms of several more recent earthquakes along the Owens Valley fault zone indicate the same oblique displacement noted by Bateman (1961) on the antithetic fault near Lone Pine (fig. 23). The mechanism in figure 23 suggests approximately equal amounts of dip-slip and right-lateral strike-slip, with the west side down along a near-vertical fault striking N. $20^{\circ} \mathrm{W}$. Assuming that the 1872 earthquake had the same focal mechanism as the composite of more recent earthquakes (fig. 23), the slipvector was about $\mathrm{N} .10^{\circ} \mathrm{W}$. for this portion of the Owens Valley fault. Thus, the 1872 earthquake probably was caused by right-oblique slip on the fault, similar to the other major earthquakes in the Nevada-California seismic zone.

\section{Long Valley Area}

Throughout the study period, earthquakes occurred in the area around Long Valley at the eastern front of the Sierra Nevada (figs. 20 and 21). Starting in 1941, an earthquake of magnitude greater than 5 has occurred in this area in each decade. Pleistocene and Holocene fault scarps are present in the area, but none appear youthful enough to correlate with specific earthquakes in the historic record. 


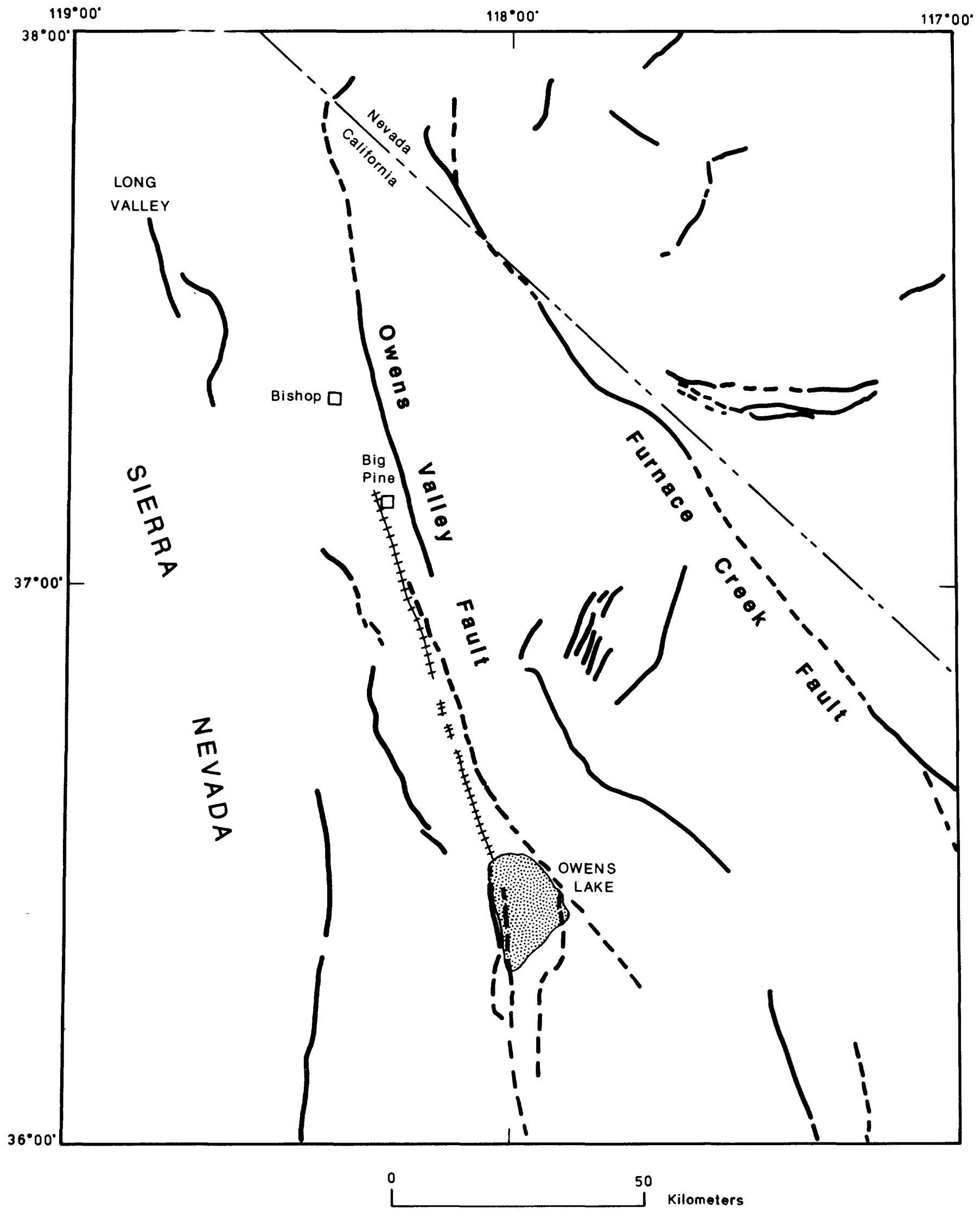

Figure 20.-- Fault pattern in the Owens Valley region. (Hachured fault ruptured in the 1872 earthquake.) 


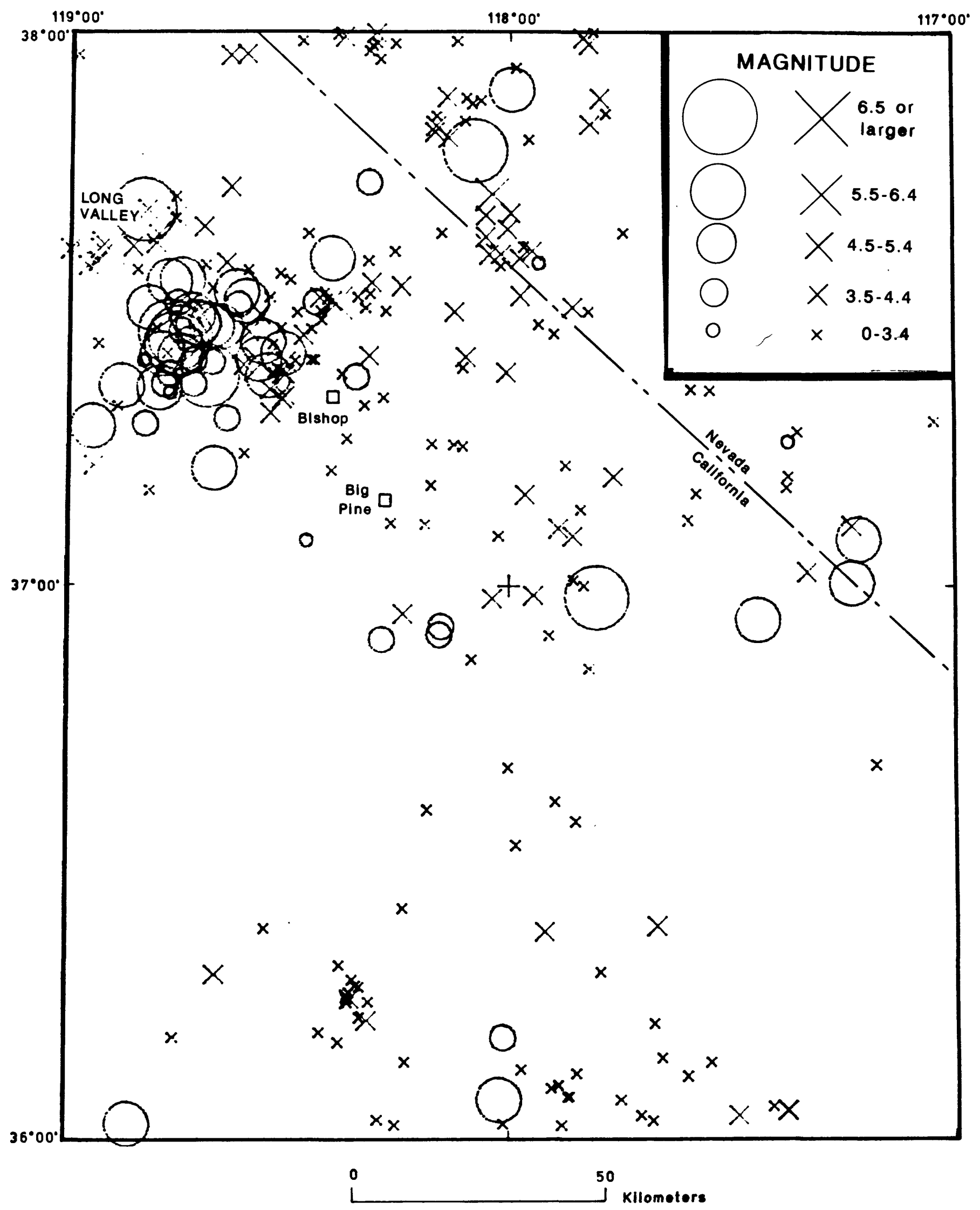

Figure 21.-- Owens Valley earthquakes 1931-1974: Epicenters of events from 1931 through 1963 (circles) and from 1964 through 1974 ( $\left.X^{\prime} s\right)$. 


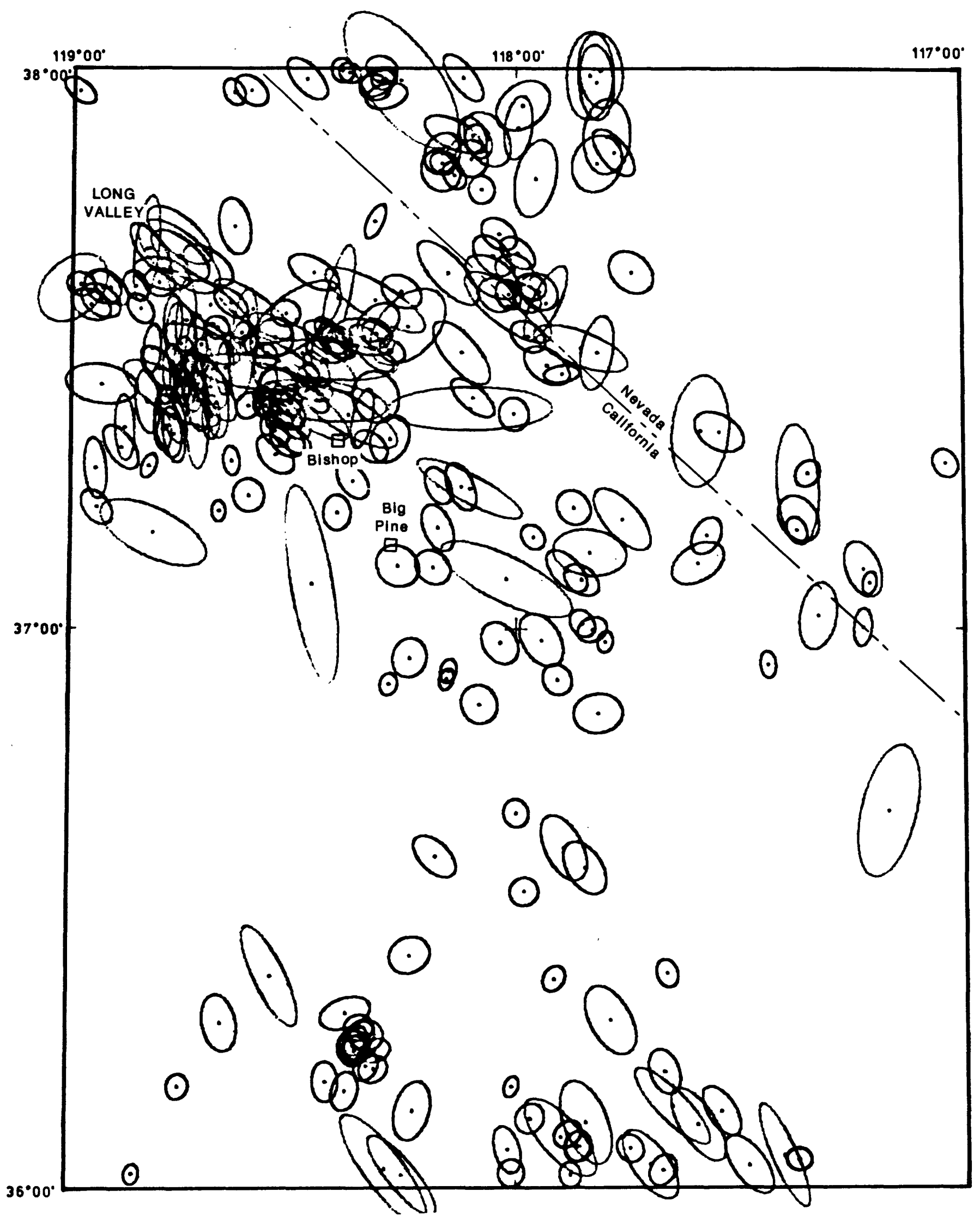

Figure 22.-- 90-percent confidence ellipses for epicenters shown on figure 21. 


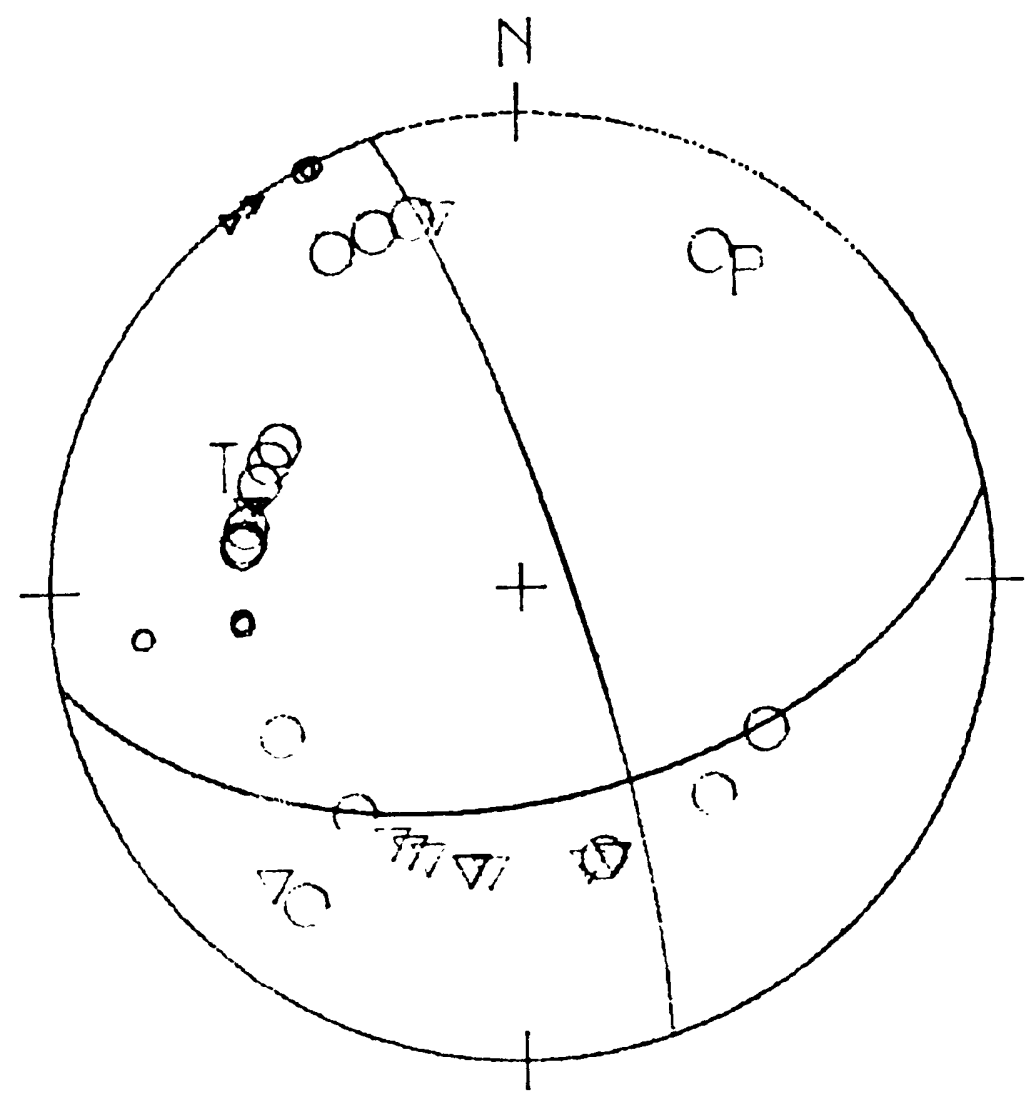

Figure 23.-- Focal mechanism plot for the Owens Valley fault zone earthquakes; composite plot of several events. (Circles are compressions, triangles are dilatations; the larger symbols represent data points considered more reliable. P-pressure axis; T-tension axis.) 
A composite focal mechanism of five earthquakes greater than magnitude 5 indicates right-oblique slip along a plane striking N. $40^{\circ} \mathrm{W}$. (fig. 24). This plane strikes farthest to the west of north of all the mechanisms shown in this paper; the slip-vector strikes $\mathrm{N} .20^{\circ} \mathrm{W}$., however, similar to the other events in the Nevada-California seismic zone, resulting in a significant highangle reverse component of motion. This mechanism is similar to one which can be obtained by using all the first motion data from two composite mechanisms published by Pitt and Steeples (1975).

\section{East-West Seismic Zone}

A band of seismicity that extends westward from the southern part of the Intermountain seismic belt in Utah, passes through south-central Nevada toward the Nevada Test Site area (Smith 1978) (fig. 25), and may continue westward to join the Nevada-California seismic zone (figs. 1 and 5 ). No obvious structural pattern correlates with this east-west zone of seismicity, although several northeast-striking seismically active fault zones occur within it (Carr, 1984). The northern edge of the zone is close to and parallels a series of east-west lineaments (Ekren and others, 1976) across south-central Nevada. The southern edge of the east-west seismic zone coincides well with a major east-west gravity gradient at about 1 at $37^{\circ} \mathrm{N}$. (Eaton and others, 1978, p. 71). Much of the Nevada Test Site lies within this zone and the underground nuclear testing conducted there has stimulated earthquake activity, particularly between about long $116^{\circ} 00^{\prime}$ and $116^{\circ} 45^{\prime} \mathrm{W}$. Separation of natural from induced activity in this area remains an important problem (Carr, 1984).

\section{Clover Mountains Earthquake}

On August 16, 1966 at 18:02:33.9 GMT, a magnitude 6.0 earthquake occurred at lat $37.39^{\circ} \mathrm{N}$. and long $114.14^{\circ} \mathrm{W}$. (fig. 26). Aftershocks for the first few days clustered about the mainshock with no significant trend, but later expanded to the west and southwest. Confidence ellipses for most of the events indicate that the north-south location precision was the weakest (fig. 26a). This implies that the vague east-west trend shown on figure $26 \mathrm{~b}$ is real. A focal mechanism of the mainshock published by Smith and Sbar (1974) shows either left-lateral slip on an east-west fault or right-lateral slip on a north-south fault. An east-west fault or fault zone is preferred because of the trend of the aftershock locations and of the east-west seismic zone in general (fig. 25); however, no specific east-west structures are known in this area. The east-west fault plane strikes N. $76^{\circ} \mathrm{W}$., and the slip would have been about $0.4 \mathrm{~m}$, as derived from a magnitude-average slip relationship (Mark and Bonilla, 1977; Mark, 1977). 


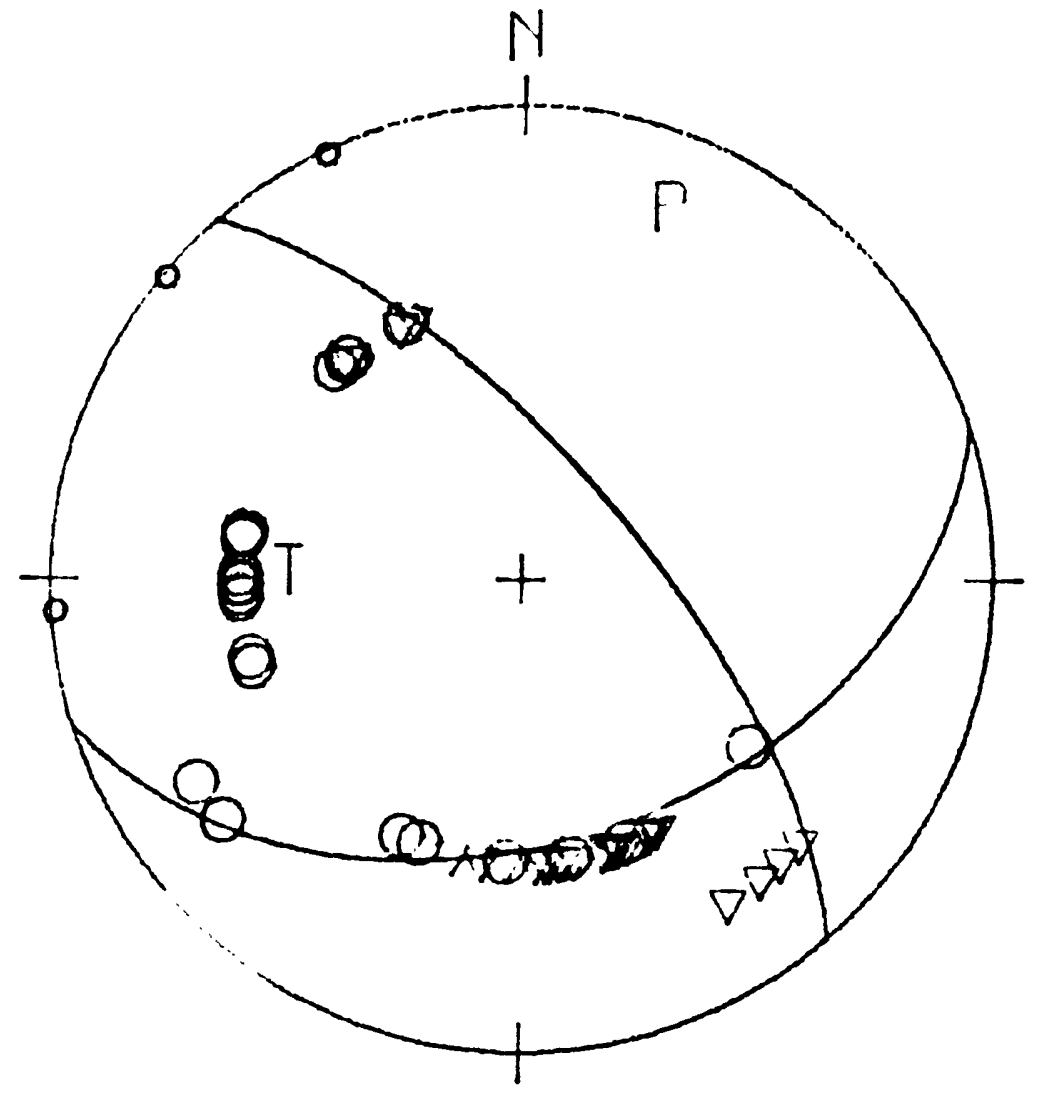

Figure 24.-- Focal mechanism plot for the Long Valley composite of five earthquakes. (Circles are compressions, triangles are dilatations; the larger symbols represent data points considered more reliable. P-pressure axis; T-tension axis.) 


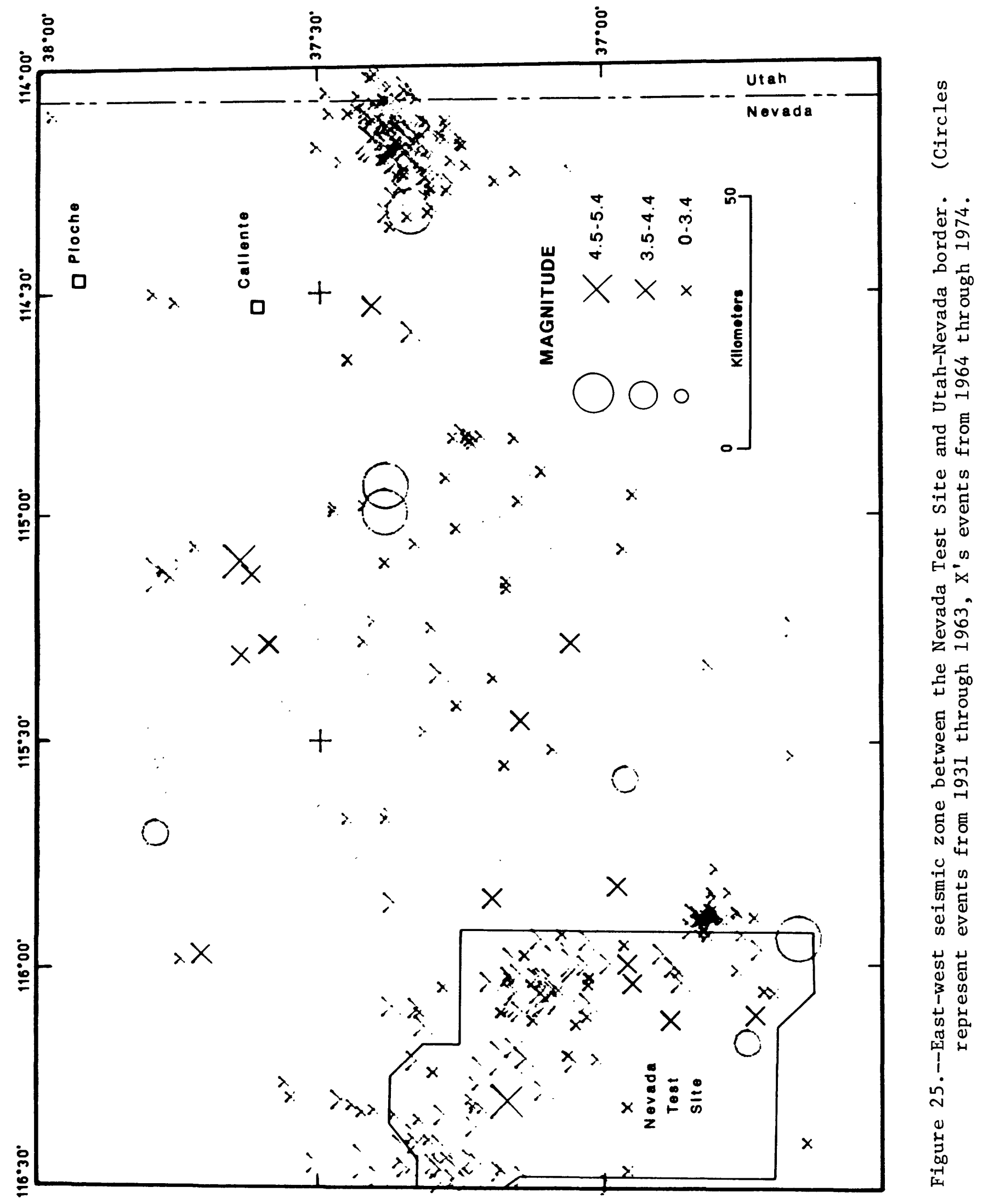



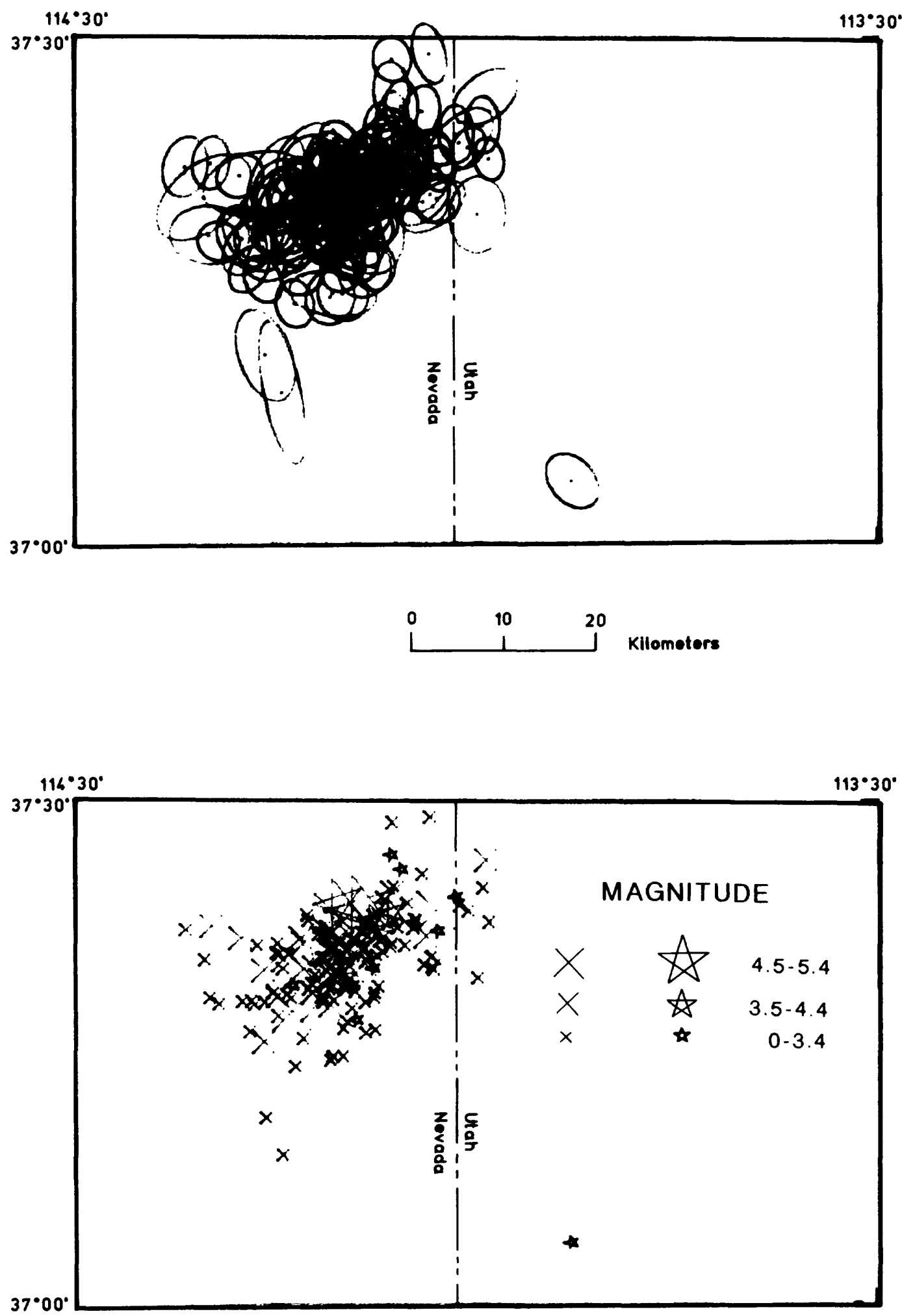

Figure 26.-- 1966 Clover Mountains earthquake. (a) 90-percent confidence ellipses for earthquakes. (b) Epicenters. (Stars are first 24 hours of events in the sequence; $X$ 's are next 6 months of events. Magnitudes were not determined for all earthquakes plotted.) 


\section{DISCUSSION AND CONCLUSIONS}

In the past, many epicenters of earthquakes in the southwestern Great Basin have been mislocated. This study has improved the accuracy of location for many of the larger earthquakes that have occurred in the region during the 45-year period preceding 1975, and together with ongoing studies, forms a better basis for analysis of regional seismotectonics. More accurate location of the major events and their foreshocks and aftershocks allows better definition of faulting mechanisms and possible tectonic interrelationships between the events.

The faults and general structure of the Basin and Range province are largely remnants of an older tectonic regime, and do not necessarily reflect the present day tectonics of the region. Although fault orientation with respect to the present stress field has been considered an important factor in the occurrence of many small earthquakes in the southwestern Great Basin (Carr, 1974; Rogers and others, 1983), slip-vectors for most major earthquakes of the region cluster about an average direction of $\mathrm{N} .20^{\circ} \mathrm{W}$. Little is known, however, about slip directions for two of the large earthquakes, the 1934 Excelsior Mountains and 1966 Clover Mountains events, both of which are unique in structural setting among the larger historic events of the Southwestern Great Basin. The Excelsior Mountains earthquake occurred in a prominent zone of east-northeast-striking faults, and the Clover Mountains earthquake occurred in the east-west seismic zone, but in an area not known to contain east-west structures.

The fairly consistent slip-vector direction in the Nevada-California seismic zone probably represents the approximate direction the area to the west, the California subplate, is moving relative to the area east of the Nevada-California seismic zone. Atwater (1970) was probably correct in stating that tectonic activity in the Nevada-California seismic zone is at least partially the result of eastward propagation of the relative motion between the Pacific and North American plates along a "soft boundary." The plate motion direction is, however, slightly oblique to the strike of the San Andreas fault, which, because it is essentially a vertical fault, cannot absorb a compressional component. This rotated component must therefore be taken up on faults on either side of the San Andreas, accompanied by an exaggerated clockwise rotation of the plate motion vector, similar to that west of the San Andreas fault in central California (Gawthrop, 1978). The plate motion should be expressed in the western Great Basin as faulting of predominantly dextral slip with a normal component of motion if the fault strike is clockwise of the slip vector. Northeast-striking faults should have a significant component of vertical or extensional displacement. Faults striking counterclockwise of the N. $20^{\circ} \mathrm{W}$. slip-vector direction should have a component of reverse movement.

It has been suggested that the tendency for clustering of earthquake focal mechanism tension axes (e.g., Smith, 1978) and other stress indicators (Carr, 1974) is evidence of west-northwest-east-southeast extension in the western Great Basin. The first author of this report believes that in the region of the Nevada-California seismic zone, clustering of slip-vectors about a N. $20^{\circ} \mathrm{W}$. direction indicates that only minor extension is occurring there because of the relatively small angular discordance between this slip direction and the strike of the major regional faults. One implication of 
this conclusion is that the current western Great Basin deformation is due to plate motion rather than to a spreading mechanism within the Great Basin.

As illustrated in this report, the spatial and temporal relationships of most of the larger earthquakes that occurred in the Nevada portion of the Nevada-California seismic belt between about 1930 and 1960 strongly suggest some sort of seismotectonic coupling between the events. 0ccurrence of aftershocks closely related in time to large events within or near zones of later rupture is considered to be evidence of a dependent relationship within changing stress conditions.

\section{REFERENCES}

Atwater, T., 1970, Implications of plate tectonics for the Cenozoic tectonic evolution of western North America: Geological Society of America Bulletin, v. 81, p. 3513-3536.

Bateman, P.C., 1961, Willard D. Johnson and the strike-slip component of fault movement in the Owens Valley, California, earthquake of 1872: Seismological Society of America Bulletin, v. 51, no. 4, p. 483-493.

Byerly, P., 193b, The first preliminary waves of the Nevada earthquake of December 20, 1932: Seismological Society of America Bulletin, v. 25, no. 1 , p. 62-80.

Callaghan, E., and Gianella, V.P., 1935, The earthquake of January 30, 1934, at Excelsior Mountains, Nevada: Seismological Society of America Bulletin, v. 2b, no. 2, p. 161 .

Carr, W.J., 1974, Summary of tectonic and structural evidence for stress orientation at the Nevada Test Site: U.S. Geological Survey Open-File Report 74-176, $53 \mathrm{p}$.

Carr, W.J., 1984, Regional structural setting of Yucca Mountain, southwestern Nevada, and late Cenozoic rates of tectonic activity in part of the southwestern Great Basin, Nevada and California: U.S. Geological Survey Open-File Report 84-854, 108 p.

Eaton, G.P., Wahl, R.R., Prostka, H.J., Mabey, D.R., and Kleinkopf, M.D., 1978, Regional gravity and tectonic patterns: Their relation to late Cenozoic epeirogeny and lateral spreading in the western Cordillera, in Smith, R.B., and Eaton, G.P., eds., Cenozoic tectonics and regional geophysics of the western Cordillera: Geological Society of America Memoir 152, p. 51-91.

Ekren, E.B., Bucknam, R.C., Carr, W.J., Dixon, G.L., and Quinlivan, W.D., 1976, East-trending structural lineaments in central Nevada: U.S. Geological Survey Professional Paper 986, $16 \mathrm{p}$.

Gawthrop, W.H., 1978, Seismicity and tectonics of the central California coastal region, in San Gregorio-Hosgri fault zone, California:

California Division of Mines and Geology Special Report 137.

Gianella, V.P., and Callaghan, E., 1934, The Cedar Mountain, Nevada, earthquake of December 20, 1932: Seismological Society of America Bulletin, v. 24, no. 4, p. 345 .

Kanamori, H., 1977, The energy release in great earthquakes: Journal of Geophysical Research, v. 82, no. 20, p. 2981-2988.

Kanamori, H., and Anderson, D.L., 197b, Theoretical basis of some empirical relationships in seismology: Seismological Society of America Bulletin, v. 6b, p. 1073-95. 
Mark, R.K., 1977, Application of linear statistical models of earthquake magnitude versus fault length in estimating maximum expectable earthquakes: Geology, v. 5, no. 8, p. 464-466.

Mark, R.K., and Bonilla, M.G., 1977, Regression analysis. of earthquake magnitude and surface fault length using the 1970 data of Bonilla and Buchanan: U.S. Geological Survey Open-File Report 77-614, 8 p.

Pitt, A.M., and Steeples, D.W., 1975, Microearthquakes in the Mono Lakenorthern Owens Valley, California region from September 28 to 0ctober 18, 1970: Seismological Society of America Bulletin, v. 65, no. 4, p. 835844.

Richter, C.F., 1958, Elementary seismology: San Francisco, Calif., W.H. Freemand and Co., $768 \mathrm{p}$.

Rogers, A.M., Harmsen, S.C., Carr, W.J., and Spence, W.J., 1983, Southern Great Basin seismological data report for 1981 and preliminary data analysis: U.S. Geological Survey Open-File Report 83-669, 240 p.

Romney, C., 1957, Seismic waves from the Dixie Valley-Fairview Peak earthquakes: Seismological Society of America Bulletin, v. 47, no. 4, p. 301-319.

Kyal1, A., and Malone, S.D., 1971, Earthquake distribution and mechanism of faulting in the Rainbow Mountain-Dixie Valley-Fairview Peak area, central Nevada: Journal of Geophysical Research, v. 76, no. 29, p. 7241-7248.

Ryal1, A., and Priestley, K., 1975, Seismicity, secular strain, and maximum magnitude in the Excelsior Mountain area, western Nevada and eastern California: Geological Society of America Bulletin, v. 86, p. 1585-1592.

Savage, J.C., and Hastie, L.M., 1969, A dislocation model for the Fairview Peak, Nevada, earthquake: Seismological Society of America Bulletin, v. 59, no. b, p. 1937-1948.

Slemmons, D.B., 1957, Geological effects of the Dixie Valley-Fairview Peak, Nevada, earthquakes of December 16, 1954: Seismological Society of America Bulletin, v. 47, no. 4, p. 353.

Slemmons, D.B., Jones, A.E., and Gimlett, J.I., 1965, Catalog of Nevada earthquakes 18b2-1960: Seismological Society of America Bulletin, v. 55, no. $2, \mu .537-583$.

Smith, R.B., 1978, Seismicity, crustal structure, and intraplate tectonics of the interior of the Western Cordillera, in Smith, R.B., and Eaton, G.P., eds., Cenozoic tectonics and regional geophysics of the Western Cordillera: Geological Society of America Memoir 152, p. 111-144.

Smith, R.B., and Sbar, M.L., 1974, Contemporary tectonics and seismicity of the western United States with emphasis on the Intermountain Seismic Belt: Geological Society of America Bulletin, v. 85, p. 1205-1218.

Tocher, D., 1956, Movement of the Rainbow Mountain fault: Seismological Society of America Bulletin, v. 46, no. 1, p. 10-14.

Wallace, R.E., 1977, Time-history analysis of fault scarps and fault traces--a longer view of seismicity: Sixth World Conference on Earthquake Enyineering, New Delhi, India, January 1977.

Whitten, C.A., 1957, Geodetic measurements in the Dixie Valley area: Seismological Society of America Bulletin, v. 47, no. 4, p. 321-325. 


\section{APPENDIX A}

Stations used in the relocation study. Latitude (Lat) and longitude (Long) are given in degrees and minutes, elevation (El) in meters, and the $\mathrm{Pn}, \mathrm{Pg}$, $\mathrm{Sn}$, and Lg time corrections are given in hundredths of seconds which are added to the calculated traveltimes. 
SEISMIC STATIONS AND CORRECTIONS

USED IN THE RELOCATION STUDY

\begin{tabular}{|c|c|c|c|c|c|c|c|}
\hline Station & Lat. & Long. & Elev., m. & $P N^{1}$ & $P G^{1}$ & $\mathrm{SN}^{1}$ & $\mathrm{LG}^{1}$ \\
\hline NEL & $35 N 42.73$ & $114 W 50.62$ & 1500 & -80 & -200 & 0 & \\
\hline DLT & $34 N 10.20$ & $117 W 48.60$ & 523 & 10 & 0 & 0 & 100 \\
\hline PFA & $36 \mathrm{~N} 7.25$ & $114 W 00.28$ & 417 & 0 & 0 & 0 & 0 \\
\hline OVE & $36 N 31.87$ & $114 W 26.55$ & 395 & 0 & 0 & 0 & \\
\hline TNP & $38 N 4.92$ & $117 \mathrm{~W} 13.00$ & 1932 & -15 & 0 & 0 & \\
\hline GCA & $36 N 58.42$ & $111 W 35.58$ & 1339 & 40 & 0 & 0 & \\
\hline FGU & $40 N 55.58$ & $109 W 23.17$ & 1982 & 129 & 0 & 0 & \\
\hline TUC & $32 N 18.58$ & $110 W 46.93$ & 985 & -88 & 0 & 0 & \\
\hline $\mathrm{BOZ}$ & $45 N 36.00$ & $111 W 38.00$ & 1575 & 74 & 0 & 0 & \\
\hline$A L Q$ & $34 N 56.50$ & $106 \mathrm{~W} 27.50$ & 1853 & -220 & 0 & 0 & 0 \\
\hline $\mathrm{HHN}$ & $48 N 20.97$ & $114 \mathrm{~W} 1.65$ & 1100 & -70 & 0 & 0 & 0 \\
\hline GOL & $39 N 42.02$ & $105 W 22.27$ & 2359 & 6 & 0 & 0 & 0 \\
\hline VIT & $36 N 45.00$ & $121 W 23.30$ & 380 & 20 & 0 & 0 & 0 \\
\hline SCC & $37 N 0.40$ & $121 W 59.80$ & 128 & 0 & 0 & 0 & \\
\hline PRC & $38 N 4.80$ & $122 W 52.00$ & 404 & 0 & 0 & 0 & \\
\hline ONC & $37 N 58.10$ & $122 W 4.30$ & 36 & -4 & 0 & 0 & \\
\hline ORV & $39 N 33.30$ & $121 W 30.02$ & 360 & -73 & 0 & 0 & \\
\hline REN & $39 N 32.40$ & $119 W 48.78$ & 1383 & -30 & -70 & 0 & \\
\hline SHS & $40 N 41.70$ & $122 W 23.30$ & 312 & -17 & 0 & 0 & 0 \\
\hline USF & $37 N 47.28$ & $122 W 23.37$ & 8 & 0 & 0 & 0 & 0 \\
\hline VIN & $36 N 45.00$ & $121 \mathrm{~W} 23.10$ & 330 & 0 & 0 & 0 & 0 \\
\hline ARC & $40 N 52.60$ & $124 \mathrm{~W} 4.50$ & 59 & 50 & 0 & 0 & 400 \\
\hline BAR & $32 N 40.80$ & $116 W 40.30$ & 510 & -43 & 0 & 0 & \\
\hline BKS & $37 N 52.60$ & $122 W 14.10$ & 276 & -66 & -192 & 0 & -200 \\
\hline BRK & $37 N 52.40$ & $122 W 15.60$ & 81 & -14 & -68 & 107 & -100 \\
\hline OLC & $35 N 49.00$ & $117 W 35.80$ & 766 & -56 & 100 & 0 & -200 \\
\hline EUR & $39 N 29.00$ & $115 w 58.20$ & 2178 & -63 & 0 & 0 & 0 \\
\hline FRE & $36 N 46.10$ & $119 W 47.80$ & 88 & 30 & 50 & -100 & \\
\hline FTC & $34 N 52.40$ & $118 w 53.60$ & 990 & 70 & -150 & 400 & -71 \\
\hline GLA & $33 N 3.15$ & $114 W 49.59$ & 627 & -48 & 0 & 0 & \\
\hline GSC & $35 N 18.10$ & $116 W 48.28$ & 990 & -50 & 0 & 0 & \\
\hline HAI & $36 \mathrm{~N} 8.20$ & $117 W 56.80$ & 1150 & 18 & 0 & 80 & 109 \\
\hline HAY & $33 N 42.50$ & $115 \mathrm{~W} 38.30$ & 439 & 12 & 250 & 0 & 104 \\
\hline ISA & $35 N 39.80$ & $118 W 28.40$ & 835 & 44 & -32 & 0 & -150 \\
\hline JAS & $37 N 56.80$ & 120 W26.30 & 457 & -77 & 0 & 0 & 0 \\
\hline KKC & $35 N 19.60$ & $119 W 44.70$ & 680 & 40 & -150 & 0 & 302 \\
\hline LLA & $36 N 37.00$ & $120 W 56.60$ & 475 & 48 & 0 & 0 & 0 \\
\hline $\mathrm{MHC}$ & $37 N 20.50$ & $121 W 38.50$ & 1282 & -2 & 0 & 229 & -100 \\
\hline MIN & $40 \mathrm{~N} 20.70$ & $121 W 36.30$ & 1495 & -42 & 0 & -18 & 0 \\
\hline MWC & $34 N 13.43$ & $118 \mathrm{~W} 3.46$ & 1730 & 50 & 200 & 0 & 66 \\
\hline PAC & $37 N 25.00$ & $122 W 10.90$ & 83 & 0 & 0 & 327 & \\
\hline PAS & $34 \mathrm{~N} 8.90$ & $118 \mathrm{~W} 10.30$ & 295 & 39 & 0 & 0 & \\
\hline PLM & $33 N 21.21$ & $116 W 51.70$ & 1692 & 1 & 0 & 0 & -18 \\
\hline PRI & $36 \mathrm{~N} 8 \mathrm{bu}$ & $120 \mathrm{w} 3990$ & 1187 & 44 & 0 & 0 & \\
\hline PRS & $36 N 19.90$ & $121 W 22.20$ & 363 & -17 & 0 & 0 & \\
\hline RUR & $33 N 59.60$ & $117 W 22.50$ & 260 & -23 & 148 & 0 & \\
\hline
\end{tabular}


SEISMIC STATIONS AND CORRECTIONS

USED IN THE RELOCATION STUDY--(CONTINUED)

\begin{tabular}{|c|c|c|c|c|c|c|c|}
\hline Station & Lat. & Lony. & Elev., m. & $\mathrm{PN}^{1}$ & $P G^{1}$ & $\mathrm{SN}^{1}$ & $\mathrm{LG}^{1}$ \\
\hline SBC & 34 N26.50 & $119 W 42.80$ & 90 & 270 & 0 & .0 & 167 \\
\hline SFR & $37 N 47.28$ & $122 W 23.37$ & 8 & 0 & 0 & 0 & 0 \\
\hline SLD & $37 N 4.48$ & $121 W 13.23$ & 443 & 4 & -92 & 0 & -400 \\
\hline SWM & $34 N 43.10$ & 118 W34.90 & 1220 & 0 & 0 & 0 & 0 \\
\hline SYP & $34 N 31.60$ & $119 w 58.70$ & 1305 & 114 & 0 & 0 & 0 \\
\hline TIN & $37 \mathrm{~N} 3.30$ & $118 W 13.70$ & 1195 & 2 & 100 & 12 & 203 \\
\hline WDY & $35 N 42.00$ & $118 W 50.60$ & 500 & -11 & -100 & 105 & -150 \\
\hline FHC & $40 N 48.10$ & $123 W 59.10$ & 610 & 0 & 0 & 0 & 0 \\
\hline GCC & $37 N 1.80$ & $121 W 59.80$ & 122 & -65 & 0 & 0 & 0 \\
\hline $\mathrm{BCN}$ & $35 N 58.85$ & $114 W 50.03$ & 776 & -19 & 0 & 0 & 0 \\
\hline BUT & $46 \mathrm{~N} \quad 0.80$ & $112 W 33.80$ & 1758 & -8 & 0 & 0 & 0 \\
\hline BZM & $45 N 40.02$ & $111 \mathrm{~W} 2.72$ & 1490 & 100 & 150 & 0 & 0 \\
\hline LJC & $32 \mathrm{NS1} 1.80$ & $117 W 15.20$ & 8 & 0 & 0 & 0 & 0 \\
\hline LOG & $41 N 44.50$ & $111 W 48.80$ & 1455 & 50 & 400 & 0 & 0 \\
\hline SLC & $40 N 45.92$ & $111 W 50.90$ & 1425 & 107 & 370 & 400 & 443 \\
\hline TUO & $32 N 14.80$ & $110 \mathrm{~W} 50.10$ & 770 & 0 & 370 & 0 & 200 \\
\hline UKI & $39 N 8.23$ & $123 W 12.63$ & 199 & 0 & 0 & 0 & 0 \\
\hline NRR & $39 N 34.32$ & $119 W 50.94$ & 1634 & 0 & 0 & 0 & 0 \\
\hline UVN & $40 N 26.54$ & $118 \mathrm{~W} 9.50$ & 1926 & 0 & 0 & 0 & 0 \\
\hline TFU & $34 N 16.07$ & $111 W 16.22$ & 1492 & 0 & 0 & 0 & 0 \\
\hline UBO & 4 UN19.30 & $109 W 34.12$ & 1596 & 0 & 0 & 0 & 0 \\
\hline DUG & $40 N 11.70$ & $112 W 48.80$ & 1477 & 0 & 0 & 0 & 0 \\
\hline BMO & $44 N 50.93$ & $117 W 18.33$ & 1189 & 0 & 0 & 0 & 0 \\
\hline$M N-$ & $38 \mathrm{~N} 26.17$ & $118 W 8.88$ & 1524 & 0 & 0 & 0 & 0 \\
\hline CWC & $36 \mathrm{~N} 26.30$ & $118 \mathrm{~W} 4.70$ & 1620 & 0 & 0 & 0 & 0 \\
\hline SAO & $36 N 45.90$ & $121 W 26.70$ & 350 & 0 & 0 & 0 & 0 \\
\hline LVN & $36 \mathrm{~N} 6.55$ & $115 \mathrm{~W} 8.40$ & 610 & 0 & 0 & 0 & 0 \\
\hline$\overline{F L G}$ & $35 N 17.59$ & $111 W 42.14$ & 2445 & 0 & 0 & 0 & 0 \\
\hline STC & $36 \mathrm{~N} 38.10$ & $121 W 14.00$ & 259 & 0 & 0 & 0 & 0 \\
\hline $\mathrm{HCC}$ & $36 N 58.88$ & $121 W 43.35$ & 159 & 0 & 0 & 0 & 0 \\
\hline MOV & $36 \mathrm{~N} 38.01$ & $115 W 59.99$ & 1158 & 0 & 0 & 0 & 0 \\
\hline CPX & $36 N 55.92$ & 116 W 3.33 & 1285 & 0 & 0 & 0 & 0 \\
\hline DAC & $36 N 16.62$ & $117 w 35.62$ & 1433 & 0 & 0 & 0 & 0 \\
\hline $\mathrm{TPH}$ & $38 \mathrm{~N} 4.48$ & $117 W 13.35$ & 1890 & 0 & 0 & 0 & 0 \\
\hline LEE & $37 N 14.58$ & $113 W 22.60$ & 1097 & 0 & 0 & 0 & 0 \\
\hline MNV & 38 N25.93 & $118 W 9.26$ & 1507 & 0 & 0 & 0 & 0 \\
\hline LSM & $36 N 44.32$ & $116 W 16.32$ & 1146 & 0 & 0 & 0 & 0 \\
\hline BMN & $40 N 25.89$ & $117 W 13.31$ & 1500 & 0 & 0 & 0 & 0 \\
\hline BTY & $36 N 53.00$ & $116 W 46.00$ & 1183 & 0 & 0 & 0 & 0 \\
\hline ELY & $39 N 7.88$ & $114 W b 3.52$ & 2011 & 0 & 0 & 0 & 0 \\
\hline SMN & $37 N 8.60$ & $116 W 46.00$ & 1341 & 0 & 0 & 0 & 0 \\
\hline NYC & $37 \mathrm{~N} 9.30$ & $116 \mathrm{~W} 9.32$ & 1695 & 0 & 0 & 0 & 0 \\
\hline FRI & $36 \mathrm{Nb} 9.50$ & $119 W 42.50$ & 119 & 0 & 0 & 0 & 0 \\
\hline NYM & $37 N 13.88$ & $116 \mathrm{~W} 3.14$ & 1603 & 0 & 0 & 0 & 0 \\
\hline NYS & $37 \mathrm{~N} 1.95$ & $116 \mathrm{~W} 10.13$ & 1509 & 0 & 0 & 0 & 0 \\
\hline NYR & $37 N 3.32$ & $116 \mathrm{~W} 5.50$ & 1279 & 0 & 0 & 0 & 0 \\
\hline
\end{tabular}


SEISMIC STATIONS AND CORRECTIONS

USED IN THE RELOCATION STUDY--(CONTINUED)

\begin{tabular}{|c|c|c|c|c|c|c|c|}
\hline Station & Lat. & Long. & Elev., m. & $\mathrm{PN}^{1}$ & $\mathrm{PG}^{1}$ & $S_{N}^{1}$ & $\mathrm{LG}^{1}$ \\
\hline NYJ & $\begin{array}{lll}37 \mathrm{~N} & 0.48\end{array}$ & $115 W b 8.48$ & 1286 & 0 & 0 & 0 & 0 \\
\hline NYV & $37 \mathrm{~N} 6.77$ & $115 W 59.40$ & 1442 & u & 0 & 0 & 0 \\
\hline PRN & $37 N 26.50$ & $115 \mathrm{~W} 4.00$ & 1524 & 0 & 0 & 0 & 0 \\
\hline LVW & $36 \times 10.20$ & $115 W 11.25$ & $6 b 4$ & 0 & 0 & 0 & 0 \\
\hline WSR & $38 N 11.48$ & 116 W23.93 & 1890 & 0 & 0 & 0 & 0 \\
\hline CLS & $38 \times 38.20$ & $122 W 35.10$ & 457 & 0 & 0 & 0 & 0 \\
\hline KN- & $37 N 1.37$ & $112 W 49.65$ & 1737 & 0 & 0 & 0 & 0 \\
\hline
\end{tabular}

$1_{10^{-2}}$ seconds. 
APPENDIX B

Gawthrop-Dewey catalog of relocated earthquakes in the southwestern Great Basin, 1931-1974. Depths are held constant at $8 \mathrm{~km}$. NOR=number of readings. 


\begin{tabular}{|c|c|c|c|c|c|}
\hline DATE (UTC) & OR I G I N & LATITUDE & LONGITUDE & $M A G$ & NO \\
\hline $1931 / 01 / 17$ & $08: 07: 21.53$ & 37.586 & -117.939 & 0. 0 & \\
\hline $1931 / 04 / 23$ & $23: 34: 03.15$ & 35.976 & -116.906 & 0.0 & \\
\hline $1932 / 12 / 21$ & $06: 10: 03.56$ & 38.833 & -117.922 & $7 \cdot 2$ & \\
\hline $1932 / 12 / 21$ & $07: 40: 56.59$ & 38.624 & -117.788 & 5.0 & \\
\hline $1932 / 12 / 21$ & $08: 48: 41.05$ & 38.435 & $-118 \cdot 308$ & $5 \cdot 0$ & \\
\hline $1932 / 12 / 21$ & $11: 33: 26.85$ & 38.676 & -117.801 & 5.5 & \\
\hline $932 / 12 / 26$ & $05: 02: 45.05$ & 38.043 & -117.957 & $5 \cdot 5$ & \\
\hline $1932 / 12 / 29$ & $06: 45: 13.92$ & 38.996 & -117.836 & 0.0 & \\
\hline $1933 / 01 / 05$ & $06: 50: 34.45$ & 37.681 & -118.836 & $5 \cdot 7$ & \\
\hline $1933 / 02 / 03$ & $03: 25: 14 \cdot 16$ & 37.595 & -118.407 & 5.0 & \\
\hline $1933 / 02 / 13$ & $22: 09: 02.79$ & 39.292 & -118.208 & 0.0 & \\
\hline $1933 / 03 / 13$ & $13: 17: 48.04$ & 37.262 & -117.373 & 0.0 & \\
\hline $933 / 05 / 09$ & $09: 46: 32.23$ & 38.456 & -117.833 & 0.0 & \\
\hline $1933 / 06 / 11$ & $08: 34: 19.52$ & 38.631 & -117.519 & 0.0 & \\
\hline $1933 / 06 / 22$ & $12: 36: 29.15$ & 37.555 & -118.747 & 4.9 & \\
\hline $1933 / 06 / 22$ & $12: 41: 03.27$ & 37.363 & -118.882 & 4.9 & \\
\hline $1933 / 06 / 23$ & $19: 54: 24.06$ & 39.711 & -119.451 & 0.0 & \\
\hline $1933 / 06 / 25$ & $20: 45: 28 \cdot 11$ & 39.133 & -119.143 & $6 \cdot 1$ & \\
\hline $1933 / 10 / 27$ & $10: 58: 58.16$ & 38.996 & -117.960 & 5.0 & \\
\hline $1934 / 01 / 30$ & $19: 23: 52.80$ & 38.261 & -118.323 & 6.6 & \\
\hline $1934 / 01 / 30$ & $20: 16: 27.77$ & 38.235 & -118.369 & 6.3 & \\
\hline $1934 / 02 / 01$ & $11: 45: 56.06$ & 37.085 & -118.462 & 0.0 & \\
\hline $1934 / 02 / 09$ & $09: 20: 38.88$ & 38.756 & -118.752 & 0.0 & \\
\hline $1936 / 05 / 10$ & $17: 40: 13 \cdot 78$ & 37.470 & -118.659 & 5.0 & \\
\hline $1936 / 07 / 02$ & $16: 29: 28.68$ & 38.870 & -117.654 & 5.0 & \\
\hline $1937 / 02 / 19$ & $09: 09: 31.43$ & 38.486 & -118.152 & 5.0 & \\
\hline $1937 / 04 / 25$ & $04: 27: 55.61$ & 38.459 & $-118 \cdot 298$ & 4.5 & \\
\hline $1937 / 08 / 19$ & $07: 03: 46.39$ & 37.899 & -118.001 & 4.5 & \\
\hline $1938 / 09 / 23$ & $08: 19: 58.93$ & 38.899 & -117.969 & 4.5 & \\
\hline $1938 / 12 / 03$ & $17: 42: 52.21$ & 37.382 & -118.689 & $5 \cdot 7$ & \\
\hline $1939 / 01 / 07$ & $20: 21: 49.34$ & 35.940 & -117.616 & 4.5 & \\
\hline $1939 / 01 / 11$ & $22: 00: 12 \cdot 44$ & 38.933 & -119.409 & $5 \cdot 5$ & \\
\hline $1939 / 05 / 04$ & $20: 44: 48.36$ & 35.768 & -114.785 & $5 \cdot 0$ & \\
\hline $1939 / 05 / 11$ & $18: 04: 45.37$ & 38.353 & -117.828 & 5.5 & \\
\hline $1939 / 06 / 13$ & $17: 15: 32.07$ & 37.007 & -117.229 & 5.0 & \\
\hline $1939 / 06 / 21$ & $11: 28: 35 \cdot 28$ & 38.230 & -117.694 & 4.5 & \\
\hline $1940 / 02 / 24$ & $09: 38: 01.84$ & 37.360 & -118.797 & 4.5 & \\
\hline $1940 / 03 / 10$ & $18: 01: 53.31$ & 37.389 & -114.937 & 5.0 & \\
\hline $1940 / 04 / 07$ & $08: 41: 52.80$ & 37.391 & -114.996 & 4.5 & \\
\hline $1940 / 07 / 08$ & $10: 04: 48.17$ & 38.235 & $-118 \cdot 129$ & 4.5 & \\
\hline $1940 / 07 / 08$ & $10: 57: 39.32$ & 37.504 & -118.822 & 4.8 & \\
\hline $1940 / 07 / 22$ & $23: 00: 35.48$ & 37.551 & -118.776 & $4 \cdot 6$ & \\
\hline $1941 / 02 / 01$ & $05: 31: 15.45$ & 39.583 & -118.584 & 5.0 & \\
\hline $1941 / 06 / 06$ & $19: 38: 47.67$ & 36.963 & -115.592 & 4.0 & \\
\hline $1941 / 07 / 18$ & $03: 53: 51.82$ & 39.526 & -118.907 & 5.0 & \\
\hline $1941 / 09 / 14$ & $16: 43: 34.32$ & 37.461 & -118.773 & $5 \cdot 8$ & \\
\hline $1941 / 09 / 14$ & $16: 55: 01.48$ & 37.473 & -118.680 & 4.5 & \\
\hline $1941 / 09 / 14$ & $18: 21: 21.04$ & 37.440 & -118.760 & $5 \cdot 5$ & \\
\hline $1941 / 09 / 14$ & $18: 39: 14.45$ & 37.451 & -118.751 & 6.0 & \\
\hline $1941 / 09 / 14$ & $21: 15: 04.95$ & 37.418 & -118.750 & 5.0 & \\
\hline $1941 / 09 / 22$ & $03: 56: 00.72$ & 37.447 & -118.731 & $3 \cdot 5$ & \\
\hline $1941 / 10 / 18$ & $10: 38: 02.80$ & 37.511 & -118.619 & $3 \cdot 5$ & \\
\hline $1941 / 10 / 23$ & $20: 44: 36.55$ & 37.290 & -118.946 & 4.5 & \\
\hline $1941 / 10 / 24$ & $17: 49: 02 \cdot 16$ & 37.368 & -118.720 & 4.0 & \\
\hline $1941 / 11 / 04$ & $02: 09: 31.32$ & 37.464 & -118.747 & 4.0 & \\
\hline $1941 / 11 / 15$ & $16: 43: 08.63$ & 37.407 & -118.678 & 4.0 & \\
\hline $1941 / 12 / 31$ & $06: 48: 47.02$ & 37.477 & -118.710 & $5 \cdot 4$ & \\
\hline $1941 / 12 / 31$ & $08: 08: 18.05$ & 37.411 & -118.719 & 4.0 & \\
\hline $1941 / 12 / 31$ & $11: 02: 28.10$ & 37.386 & -118.774 & 4.0 & \\
\hline $1941 / 12 / 31$ & $11: 14: 58.43$ & 37.514 & -118.757 & 4.0 & \\
\hline
\end{tabular}




\begin{tabular}{|c|c|c|c|c|c|}
\hline DATE (UTC) & ORIGIN TIME & LATITUDE & LONGITUDE & $M A G$ & NOR \\
\hline $1941 / 12 / 31$ & $12: 20: 18 \cdot 39$ & 37.366 & -118.785 & 4.0 & \\
\hline $1941 / 12 / 31$ & $18: 05: 46.34$ & 37.491 & -118.724 & 4.5 & 16 \\
\hline $1942 / 01 / 01$ & $21: 56: 34.09$ & 37.351 & -118.772 & 3.0 & 13 \\
\hline $1942 / 01 / 02$ & $15: 09: 10.76$ & 37.410 & -118.831 & 3.0 & 15 \\
\hline $1942 / 07 / 11$ & $16: 41: 53: 13$ & 38.731 & -117.918 & 5.0 & 25 \\
\hline $1942 / 08 / 18$ & $21: 55: 34.09$ & 38.158 & -118.228 & 5.0 & 35 \\
\hline $942 / 12 / 03$ & $09: 44: 43.45$ & 39.598 & -119.291 & 5.5 & 21 \\
\hline $942 / 12 / 17$ & $15: 07: 43.83$ & 38.554 & -119.765 & $5 \cdot 1$ & 24 \\
\hline $1943 / 03 / 30$ & $21: 07: 33.76$ & 38.914 & -120.465 & $5 \cdot 3$ & 24 \\
\hline $1943 / 08 / 09$ & $05: 30: 08.93$ & 37.789 & -118.084 & 5.5 & 22 \\
\hline $1943 / 09 / 16$ & $07: 52: 22.00$ & 35.979 & -117.711 & $4 \cdot 5$ & 27 \\
\hline $944 / 07 / 03$ & $05: 38: 23.01$ & 35.345 & -117.889 & 4.7 & 19 \\
\hline $1945 / 06 / 14$ & $03: 31: 15.66$ & 36.941 & -117.441 & 5.0 & \\
\hline $1946 / 01 / 13$ & $16: 31: 14.63$ & 37.412 & -118.572 & 4.7 & 31 \\
\hline $1946 / 03 / 15$ & $13: 21: 01.06$ & 35.731 & -117.978 & 5.2 & 17 \\
\hline $1946 / 03 / 15$ & $13: 49: 36 \cdot 56$ & 35.683 & -117.899 & 0.0 & 18 \\
\hline $1946 / 03 / 15$ & $19: 18: 54 \cdot 26$ & 35.660 & -117.886 & 5.4 & 14 \\
\hline $1946 / 03 / 16$ & $09: 46: 18.03$ & 35.693 & -118.015 & $5 \cdot 1$ & 28 \\
\hline $1946 / 03 / 16$ & $09: 46: 18.70$ & 35.704 & -117.927 & 0.0 & 15 \\
\hline $1946 / 03 / 17$ & $14: 45: 54.18$ & 38.426 & -118.165 & 5.0 & 21 \\
\hline $1946 / 03 / 17$ & $14: 45: 53.61$ & 38.416 & -118.350 & 5.0 & 14 \\
\hline $1946 / 03 / 18$ & $10: 05: 55.73$ & 35.571 & -117.963 & 0.0 & o \\
\hline $1946 / 03 / 18$ & $15: 49: 26.48$ & 35.715 & -117.790 & 4.8 & 14 \\
\hline $1946 / 03 / 18$ & $15: 50: 41.23$ & 35.704 & -117.877 & $5 \cdot 3$ & 12 \\
\hline $1946 / 04 / 27$ & $02: 18: 21.96$ & 38.631 & -118.022 & 4.7 & 23 \\
\hline $1948 / 02 / 11$ & $03: 29: 27.91$ & 36.029 & -118.854 & 4.6 & 33 \\
\hline $1948 / 12 / 28$ & $02: 25: 38.93$ & 39.694 & -119.978 & $4 \cdot 7$ & 16 \\
\hline $1948 / 12 / 28$ & $05: 26: 04.35$ & 39.653 & -119.998 & 4.5 & 18 \\
\hline $1948 / 12 / 29$ & $12: 53: 27 \cdot 38$ & 39.620 & -119.948 & 6.0 & 30 \\
\hline $1949 / 01 / 20$ & $07: 59: 27.79$ & 39.624 & -119.987 & 4.8 & 21 \\
\hline $1949 / 02 / 11$ & $21: 05: 23: 30$ & 36.983 & -117.805 & 5.6 & 37 \\
\hline $1949 / 04 / 13$ & $07: 58: 27.23$ & 37.421 & -118.790 & 4.5 & 39 \\
\hline $1949 / 12 / 09$ & $08: 41: 21.61$ & 37.305 & -118.643 & 4.1 & 36 \\
\hline $1949 / 12 / 09$ & $12: 39: 05.72$ & 37.214 & -118.671 & 4.6 & 35 \\
\hline $1950 / 10 / 17$ & $03: 54: 17.23$ & 40.088 & -118.880 & 4.3 & 22 \\
\hline $1950 / 10 / 23$ & $08: 12: 49.57$ & 39.234 & -117.583 & 4.6 & 42 \\
\hline $1950 / 12 / 14$ & $08: 59: 33.23$ & 40.085 & -120.056 & 4.5 & 26 \\
\hline $1950 / 12 / 14$ & $09: 29: 52.74$ & 40.074 & -120.121 & 4.0 & 29 \\
\hline $1950 / 12 / 14$ & $13: 24: 19.75$ & 40.127 & -120.068 & 5.6 & 38 \\
\hline $1951 / 01 / 22$ & $15: 14: 53.35$ & 39.112 & -119.935 & 4.8 & 39 \\
\hline $1951 / 06 / 16$ & $05: 52: 55.32$ & 37.085 & -117.213 & 4.5 & 40 \\
\hline $1951 / 12 / 28$ & $02: 49: 27.23$ & 37.516 & -118.601 & 5.2 & 46 \\
\hline $1952 / 05 /$ & $15: 31: 31.04$ & 39.394 & -119.730 & 5.5 & 41 \\
\hline $1952 / 05 / 24$ & $04: 15: 15.44$ & 35.939 & -114.732 & 4.9 & 42 \\
\hline $1952 / 11 / 13$ & $00: 55: 14.81$ & 38.556 & -118.383 & 4.8 & 35 \\
\hline $1953 / 08 / 09$ & $22: 00: 00.40$ & 37.343 & -114.326 & 4.5 & 34 \\
\hline $1953 / 09 / 26$ & $03: 34: 29.83$ & 39.595 & -119.921 & 5.3 & 37 \\
\hline $1953 / 11 / 24$ & $05: 46: 05.42$ & 35.712 & -116.954 & 4.9 & 9 \\
\hline $1954 / 07 / 02$ & $10: 43: 13 \cdot 30$ & 38.149 & -116.395 & 5.2 & 51 \\
\hline $1954 / 07 / 06$ & $11: 13: 18.69$ & 39.446 & -118.461 & 6.8 & 39 \\
\hline $1954 / 07 / 06$ & $11: 49: 01.05$ & 39.295 & -118.584 & 5.7 & 39 \\
\hline $1954 / 07 / 06$ & $12: 54: 00.35$ & 39.396 & -118.523 & 4.5 & 27 \\
\hline $1954 / 07 / 06$ & $12: 56: 29.85$ & 39.298 & -118.540 & 4.9 & 24 \\
\hline $1954 / 07 / 06$ & $13: 15: 12.49$ & 39.264 & -118.598 & 5.2 & 42 \\
\hline $1954 / 07 / 06$ & $13: 36: 02.72$ & 39.132 & -118.722 & 4.5 & 21 \\
\hline $1954 / 07 / 06$ & $14: 55: 14.31$ & 39.418 & -118.379 & 4.5 & 19 \\
\hline $1954 / 07 / 06$ & $17: 57: 37.67$ & 39.447 & -118.608 & 4. 1 & 15 \\
\hline $1954 / 07 / 06$ & $22: 07: 41.64$ & 39.357 & -118.524 & 6.0 & 39 \\
\hline $1954 / 87 / 06$ & $23: 11: 21.56$ & 39.391 & -118.814 & 4.1 & 15 \\
\hline $1954 / 07 / 06$ & $23: 57: 06.49$ & 39.465 & -118.495 & 4.1 & 17 \\
\hline
\end{tabular}




\begin{tabular}{|c|c|c|c|c|c|}
\hline ( U T C ) & OR I G I N & LATITUDE & LONGITUDE & $M A G$ & NOR \\
\hline $1954 / 07 / 07$ & $00: 22: 56.91$ & 39.326 & -118.373 & 4.4 & 22 \\
\hline $1954 / 07 / 07$ & $02: 23: 47.04$ & 39.373 & -118.657 & $4 \cdot 1$ & 24 \\
\hline $1954 / 07 / 07$ & $04: 33: 53.69$ & 39.611 & -118.517 & $4 \cdot 1$ & 32 \\
\hline $1954 / 07 / 07$ & $06: 11: 19.16$ & 39.278 & -118.565 & 4.6 & 42 \\
\hline $1954 / 07 / 07$ & $10: 31: 33.07$ & 39.194 & -118.670 & 4.1 & 21 \\
\hline $1954 / 07 / 07$ & $10: 52: 48.22$ & 39.246 & -118.568 & 4.4 & 36 \\
\hline $1954 / 07 / 07$ & $12: 40: 52.80$ & 39.284 & -118.509 & $4 \cdot 2$ & 22 \\
\hline $1954 / 07 / 07$ & $16: 02: 24 \cdot 13$ & 39.423 & -118.501 & $4 \cdot 2$ & 25 \\
\hline $1954 / 07 / 07$ & $18: 00: 07.55$ & 39.348 & -118.681 & $4 \cdot 3$ & 26 \\
\hline $1954 / 07 / 07$ & $21: 47: 50.18$ & 39.675 & -118.640 & $4 \cdot 1$ & 16 \\
\hline $1954 / 07 / 07$ & $23: 51: 18.27$ & 39.129 & -118.580 & $4 \cdot 3$ & 17 \\
\hline $1954 / 07 / 08$ & $02: 13: 56.91$ & 39.474 & -118.610 & 4.8 & 46 \\
\hline $1954 / 07 / 08$ & $04: 08: 20.28$ & 39.550 & -118.530 & 4.5 & 27 \\
\hline $1954 / 07 / 08$ & $06: 58: 37.61$ & 39.156 & -118.726 & $4 \cdot 3$ & 17 \\
\hline $1954 / 07 / 08$ & $12: 55: 12.41$ & 39.359 & -118.564 & $4 \cdot 7$ & 45 \\
\hline $1954 / 07 / 08$ & $19: 31: 58.93$ & 39.332 & -118.561 & $5 \cdot 3$ & 44 \\
\hline $1954 / 07 / 09$ & $08: 50: 01.02$ & 39.427 & -118.538 & 4.9 & 51 \\
\hline $1954 / 07 / 10$ & $01: 22: 21.73$ & 39.442 & -118.611 & $4 \cdot 6$ & 41 \\
\hline $1954 / 07 / 11$ & $07: 04: 44.23$ & 39.476 & -118.566 & 4.6 & 48 \\
\hline $1954 / 07 / 11$ & $09: 58: 12.33$ & 39.241 & -118.539 & 4.6 & 47 \\
\hline $1954 / 07 / 12$ & $10: 17: 05.63$ & 39.283 & -118.482 & 4.5 & 53 \\
\hline $1954 / 07 / 12$ & $16: 05: 20.45$ & 39.463 & -118.557 & $5 \cdot 1$ & 49 \\
\hline $1954 / 07 / 15$ & $01: 31: 36.38$ & 39.561 & -118.616 & $3 \cdot 9$ & 22 \\
\hline $1954 / 07 / 17$ & $00: 02: 13.87$ & 39.487 & -118.286 & 4.2 & 18 \\
\hline $1954 / 07 / 17$ & $01: 53: 11.67$ & 39.254 & -118.632 & $4 \cdot 4$ & 15 \\
\hline $1954 / 07 / 17$ & $22: 02: 44.26$ & 38.132 & -116.342 & $4 \cdot 3$ & 20 \\
\hline $1954 / 07 / 20$ & $00: 11: 38.29$ & 38.184 & -116.363 & 5.0 & 43 \\
\hline $1954 / 07 / 20$ & $01: 41: 56.02$ & 39.408 & -118.575 & 4.1 & 52 \\
\hline $1954 / 07 / 20$ & $12: 13: 23.82$ & 39.440 & -118.674 & 3.9 & 36 \\
\hline $1954 / 07 / 20$ & $15: 28: 13.07$ & 39.180 & -118.674 & $4 \cdot 1$ & 30 \\
\hline $1954 / 07 / 23$ & $20: 41: 56.47$ & 39.361 & -118.411 & 3.6 & 21 \\
\hline $1954 / 07 / 26$ & $13: 16: 27.14$ & 39.448 & -118.416 & 3.9 & 21 \\
\hline $1954 / 07 / 30$ & $02: 00: 08.02$ & 39.557 & -118.456 & 5.1 & 49 \\
\hline $1954 / 07 / 31$ & $13: 54: 37.45$ & 39.523 & -118.576 & 4.3 & 45 \\
\hline $1954 / 07 / 31$ & $17: 24: 14.99$ & 39.570 & -118.560 & 4.5 & 42 \\
\hline $1954 / 07 / 31$ & $17: 31: 14.93$ & 39.590 & $-118 \cdot 446$ & $4 \cdot 3$ & 35 \\
\hline $1954 / 08 / 02$ & $10: 18: 52.68$ & 39.481 & -118.479 & $5 \cdot 4$ & 53 \\
\hline $1954 / 08 / 03$ & $21: 24: 55.87$ & 39.639 & -118.494 & $4 \cdot 7$ & 49 \\
\hline $1954 / 08 / 05$ & $05: 03: 07.25$ & 39.476 & -118.244 & 4.7 & 56 \\
\hline $1954 / 08 / 06$ & $15: 41: 17.68$ & 39.371 & -118.660 & $4 \cdot 2$ & 36 \\
\hline $\begin{array}{l}1954 / 08 / 16 \\
1954 / 08 / 24\end{array}$ & $\begin{array}{l}06: 29: 38.75 \\
05: 51: 30.92\end{array}$ & $\begin{array}{l}39.123 \\
39.485\end{array}$ & $\begin{array}{r}-118 \cdot 744 \\
-118.404\end{array}$ & $\begin{array}{l}4 \cdot 1 \\
6.8\end{array}$ & $\begin{array}{l}16 \\
41\end{array}$ \\
\hline $1954 / 08 / 24$ & $06: 32: 30.97$ & 39.491 & -118.489 & 4.4 & 19 \\
\hline $1954 / 08 / 24$ & $06: 36: 02.69$ & 39.588 & -118.555 & 4.4 & 25 \\
\hline $1954 / 08 / 24$ & $06: 54: 09.71$ & 39.493 & -118.503 & $4 \cdot 3$ & 26 \\
\hline $1954 / 08 / 24$ & $14: 47: 18.15$ & 39.630 & -118.399 & 4.0 & 10 \\
\hline $\begin{array}{l}1954 / 08 / 24 \\
1954 / 06 / 25\end{array}$ & $\begin{array}{l}21: 20: 53.04 \\
02: 17: 11.76\end{array}$ & $\begin{array}{l}39.595 \\
39.609\end{array}$ & $\begin{array}{l}-118.499 \\
-118.598\end{array}$ & $\begin{array}{l}4.4 \\
4.8\end{array}$ & $\begin{array}{l}39 \\
45\end{array}$ \\
\hline $1954 / 08 / 25$ & $02: 50: 00.83$ & 39.487 & -118.647 & 4.0 & 34 \\
\hline $1954 / 08 / 25$ & $12: 12: 55.68$ & 39.570 & -118.765 & 4.0 & 30 \\
\hline $1954 / 08 / 25$ & $22: 21: 12.63$ & 39.402 & -118.648 & 4.7 & 40 \\
\hline $1954 / 08 / 26$ & $12: 44: 19.64$ & 39.413 & -118.687 & $4 \cdot 2$ & 17 \\
\hline $1954 / 08 / 26$ & $12: 56: 12.66$ & 39.619 & -118.504 & 4.6 & 43 \\
\hline $1954 / 08 / 27$ & $07: 05: 02.19$ & 39.726 & -118.525 & 4.0 & 21 \\
\hline $1954 / 08 / 28$ & $04: 51: 35.60$ & 39.671 & -118.704 & 4.0 & 21 \\
\hline $1954 / 08 / 29$ & $03: 09: 50.17$ & 39.549 & -118.446 & 4.2 & 19 \\
\hline $1954 / 08 / 29$ & $03: 41: 06.00$ & 39.641 & $-118 \cdot 358$ & $4 \cdot 7$ & 50 \\
\hline $1954 / 08 / 29$ & $03: 58: 05.68$ & 39.651 & $-118 \cdot 346$ & 4.8 & 46 \\
\hline $\begin{array}{l}1954 / 08 / 30 \\
1954 / 08 / 30\end{array}$ & $\begin{array}{l}11: 15: 38.80 \\
19: 11: 54.86\end{array}$ & $\begin{array}{l}39.462 \\
39.667\end{array}$ & $\begin{array}{r}-118.520 \\
-118.329\end{array}$ & $\begin{array}{l}4 \cdot 1 \\
4 \cdot 1\end{array}$ & $\begin{array}{l}24 \\
36\end{array}$ \\
\hline
\end{tabular}




\begin{tabular}{|c|c|c|c|c|c|}
\hline OATE (UTC) & $O R \backslash G \backslash N$ & LATITUOE & LONGITUOE & $M A C$ & NOR \\
\hline $1954 / 88 / 30$ & $19: 57: 01.50$ & 39.640 & -118.457 & $4 \cdot 1$ & 26 \\
\hline $1954 / 08 / 31$ & $13: 28: 01.06$ & 39.634 & -118.387 & 3.0 & 32 \\
\hline $1954 / 08 / 31$ & $13: 34: 06.67$ & 39.382 & -118.472 & 4.0 & 14 \\
\hline $1954 / 08 / 31$ & $22: 19: 26.47$ & 39.698 & -118.314 & 4.4 & 38 \\
\hline $1054 / 08 / 31$ & $22: 20: 34.55$ & 39.627 & -118.095 & 3.8 & 20 \\
\hline $1054 / 00 / 01$ & $05: 18: 47.55$ & 30.512 & -118.527 & $5 \cdot 5$ & 48 \\
\hline $1054 / 00 / 01$ & $11: 20: 21.00$ & 39.613 & -118.402 & 4.3 & 44 \\
\hline $1054 / 09 / 02$ & $07: 53: 18.07$ & 30.500 & -118.566 & $3 \cdot 9$ & 18 \\
\hline $1054 / 00 / 02$ & $13: 26: 49.72$ & 39.644 & -118.435 & 4.7 & 44 \\
\hline $1054 / 00 / 04$ & $04: 24: 18.43$ & 30.753 & -118.328 & 4.0 & 34 \\
\hline $1954 / 00 / 05$ & $20: 16: 00.49$ & 39.492 & -118.625 & 4.4 & 40 \\
\hline $1954 / 00 / 08$ & $07: 17: 20.92$ & 39.649 & -118.535 & 4.3 & 41 \\
\hline $1054 / 00 / 00$ & $09: 21: 10.45$ & 39.574 & -118.527 & 4.0 & 55 \\
\hline $1934 / 00 / 00$ & $22: 31: 40.80$ & 39.438 & -118.700 & 4.4 & 37 \\
\hline $1954 / 00 / 14$ & $16: 10: 01.05$ & 39.347 & -118.544 & 4.0 & 44 \\
\hline $1054 / 00 / 20$ & $03: 47: 55.33$ & 37.798 & -115.713 & 4.4 & 43 \\
\hline $1054 / 10 / 16$ & $04: 32: 08.20$ & 39.727 & -118.545 & $4 \cdot 3$ & 45 \\
\hline $1054 / 10 / 20$ & $19: 53: 48.79$ & 39.588 & -118.549 & $4 \cdot 4$ & 45 \\
\hline $1054 / 11 / 13$ & $22: 06: 24.36$ & 39.537 & -118.447 & 4.2 & 27 \\
\hline $1054 / 12 / 15$ & $06: 30: 40.24$ & 39.477 & -118.336 & 4.0 & 20 \\
\hline $1054 / 12 / 16$ & $11: 07: 11.70$ & 39.320 & -118.161 & 7.2 & 33 \\
\hline $1954 / 12 / 16$ & $13: 15: 06.06$ & 39.568 & -118.124 & 5.0 & 26 \\
\hline $1054 / 12 / 16$ & $14: 16: 50.70$ & 30.458 & -118.182 & 5.8 & 43 \\
\hline $1954 / 12 / 10$ & $15: 09: 45.63$ & 39.514 & -118.120 & $5 \cdot 1$ & 36 \\
\hline $1954 / 12 / 16$ & $21: 48: 38.90$ & 39.173 & -118.085 & 4.5 & 35 \\
\hline $1954 / 12 / 17$ & $10: 33: 32.08$ & 39.393 & -118.121 & 4.7 & 47 \\
\hline $1054 / 12 / 17$ & $20: 27: 01.80$ & 39.243 & -118.083 & $5 \cdot 0$ & 46 \\
\hline $1054 / 12 / 18$ & $01: 45: 40.10$ & 39.587 & -118.135 & 4.7 & 49 \\
\hline $\begin{array}{l}1954 / 12 / 10 \\
1954 / 12 / 20\end{array}$ & $\begin{array}{l}04: 00: 03.60 \\
02: 27: 35.18\end{array}$ & $\begin{array}{l}39.363 \\
39.468\end{array}$ & $\begin{array}{l}-118.551 \\
-118.112\end{array}$ & $\begin{array}{l}4.2 \\
4.0\end{array}$ & 14 \\
\hline $1954 / 12 / 20$ & $15: 48: 53.80$ & 38.997 & -118.150 & $4 \cdot 2$ & 24 \\
\hline $1054 / 12 / 20$ & $17: 36: 40.41$ & 39.842 & -117.050 & 5.0 & 46 \\
\hline $1054 / 12 / 22$ & $01: 44: 27.19$ & 39.095 & -118.404 & 0.0 & 23 \\
\hline $1954 / 12 / 22$ & $06: 43: 45.71$ & 39.086 & -118.133 & 0.0 & 24 \\
\hline $1954 / 12 / 22$ & $07: 14: 14.78$ & 39.346 & -118.104 & 4.1 & 48 \\
\hline $1954 / 12 / 22$ & $10: 39: 19.10$ & 38.977 & -118.149 & $4 \cdot 2$ & 49 \\
\hline $1054 / 12 / 30$ & $14: 20: 05.64$ & 30.155 & -118.105 & 0 & 38 \\
\hline $1954 / 12 / 31$ & $16: 56: 55.88$ & 37.381 & -118.350 & 4.0 & 28 \\
\hline $1055 / 01 / 01$ & $12: 13: 56.38$ & 39.004 & -118.171 & $5 \cdot 1$ & 48 \\
\hline $1055 / 01 / 02$ & $22: 07: 04.33$ & 39.431 & -118.186 & 4.2 & 19 \\
\hline $1055 / 01 / 00$ & $00: 10: 50.20$ & 39.177 & -118.110 & 5.0 & 54 \\
\hline $1955 / 01 / 10$ & $13: 15: 53.79$ & 39.720 & -118.220 & 4.1 & 30 \\
\hline $1955 / 01 / 11$ & $10: 21: 30.73$ & 39.285 & -118.161 & 4.7 & 45 \\
\hline $1055 / 01 / 10$ & $02: 10: 00.08$ & 39.532 & -118.182 & 4.6 & 27 \\
\hline $1055 / 01 / 10$ & $03: 20: 17.60$ & 39.418 & -118.012 & 4.4 & 32 \\
\hline $1055 / 01 / 21$ & $11: 57: 44.66$ & 38.930 & -118.156 & 3.8 & 32 \\
\hline $1055 / 01 / 21$ & $12: 02: 16.86$ & 35.249 & -118.596 & 3.1 & 21 \\
\hline $1055 / 01 / 21$ & $12: 21: 00.32$ & 36.915 & -118.160 & 4.0 & 38 \\
\hline $1055 / 01 / 25$ & $23: 26: 44.23$ & 39.016 & -118.124 & 4.7 & 44 \\
\hline $1955 / 01 / 26$ & $15: 38: 08.51$ & 39.612 & -118.110 & 4.2 & 33 \\
\hline $1055 / 02 / 11$ & $16: 12: 33.82$ & 39.474 & -118.007 & 4.7 & 51 \\
\hline $1055 / 02 / 13$ & $00: 23: 04.02$ & 36.906 & -118.290 & $4 \cdot 1$ & 38 \\
\hline $1055 / 02 / 10$ & $23: 48: 27.86$ & 39.501 & -118.200 & $4 \cdot 1$ & 24 \\
\hline $1055 / 02 / 10$ & $23: 50: 25.04$ & 39.295 & -118.241 & 4.8 & 30 \\
\hline $1055 / 03 / 08$ & $20: 05: 18.48$ & 39.334 & -118.541 & 4.5 & 54 \\
\hline $1055 / 03 / 00$ & $23: 28: 10.12$ & 39.451 & -118.413 & 4.2 & 32 \\
\hline $1955 / 03 / 13$ & $08: 41: 08.30$ & 39.542 & -118.272 & $4 \cdot 3$ & 40 \\
\hline $1055 / 03 / 14$ & $18: 23: 48.48$ & 39.481 & -118.232 & 4.7 & 41 \\
\hline $1955 / 03 / 22$ & $03: 15: 14.28$ & 39.511 & -118.141 & 4.4 & 41 \\
\hline $1955 / 03 / 22$ & $04: 06: 16.30$ & 39.411 & -118.270 & $4 \cdot 4$ & 44 \\
\hline
\end{tabular}




\begin{tabular}{|c|c|c|c|c|c|}
\hline (UIC) & $C D \perp C \mid N$ TIUE & LATITUEE & $\angle C A C I T U D E$ & NAC & AOR \\
\hline $1055 / 03 / 30$ & E9:24:30.es & 38.065 & -118.106 & 4.3 & 43 \\
\hline $1053 / 04 / 13$ & $11: 33: 00.40$ & 39.520 & -118.215 & 4.4 & 45 \\
\hline $1055 / 05 / 08$ & $10: 38: 34.09$ & 38.992 & -118.163 & 4.5 & 56 \\
\hline $1955 / 05 / 30$ & $21: 28: 28.63$ & 30.247 & $-118 \cdot 130$ & 4.5 & 41 \\
\hline $1055 / 06 / 08$ & $12: 22: 14.57$ & 38.974 & -118.189 & 4.5 & 50 \\
\hline $1955 / 06 / 10$ & $19: 21: 01.04$ & 38.969 & -118.140 & 4.9 & 56 \\
\hline $1055 / 06 / 19$ & $10: 25: 14.19$ & 39.145 & -117.986 & 5.0 & 47 \\
\hline $1055 / 08 / 08$ & $10: 35: 36.68$ & 38.321 & -118.781 & 5.2 & 51 \\
\hline $1055 / 08 / 00$ & $05: 24: 25.73$ & 39.068 & -118.085 & $4 \cdot 2$ & 22 \\
\hline $1055 / 08 / 22$ & $14: 41: 20.71$ & 35.726 & -118.034 & $3 \cdot 9$ & 34 \\
\hline $1955 / 00 / 03$ & $11: 06: 49.21$ & 38.186 & -118.878 & $3 \cdot 3$ & 25 \\
\hline $1953 / 00 / 21$ & $07: 37: 30.91$ & 40.059 & -119.851 & $4 \cdot 1$ & 30 \\
\hline $1055 / 09 / 28$ & $09: 52: 35.05$ & 30.208 & -119.305 & 4.2 & 46 \\
\hline $1055 / 00 / 29$ & $05: 40: 52.91$ & 39.212 & -118.050 & 4.5 & 42 \\
\hline $1055 / 11 / 02$ & $06: 15: 17.98$ & 39.586 & -118.050 & 4.6 & 45 \\
\hline $1055 / 11 / 08$ & $02: 40: 53.80$ & 37.293 & -118.827 & 4.2 & 42 \\
\hline $1055 / 11 / 21$ & $20: 25: 34.01$ & 39.444 & -118.118 & $3 \cdot 5$ & 33 \\
\hline $1953 / 11 / 21$ & $20: 40: 35.59$ & 39.473 & -118.133 & 4.4 & 22 \\
\hline $1955 / 11 / 25$ & $16: 30: 05.23$ & 39.426 & -118.214 & $4 \cdot 3$ & 32 \\
\hline $1955 / 11 / 25$ & $18: 26: 52.98$ & 39.515 & -118.081 & $4 \cdot 2$ & 25 \\
\hline $1955 / 12 / 01$ & $10: 25: 00.27$ & 39.505 & -118.145 & 4.3 & 48 \\
\hline $1055 / 12 / 22$ & $12: 05: 11.47$ & 38.935 & -118.806 & 4.8 & 42 \\
\hline $1955 / 12 / 31$ & $13: 51: 08.14$ & 39.028 & -118.106 & 4.5 & 41 \\
\hline $1956 / 01 / 28$ & $22: 35: 27 \cdot 34$ & 39.020 & -118.093 & 4.2 & 41 \\
\hline $1956 / 03 / 08$ & $07: 26: 22.87$ & 39.039 & -118.095 & 4.6 & 44 \\
\hline $1036 / 04 / 09$ & $04: 42: 26.26$ & 30.449 & -118.169 & $4 \cdot 3$ & 47 \\
\hline $1956 / 07 / 06$ & $03: 31: 35.53$ & 38.582 & -118.444 & 4.9 & 48 \\
\hline $1956 / 07 / 11$ & $19: 22: 05.76$ & 35.729 & -117.882 & $4 \cdot 2$ & 14 \\
\hline $1956 / 07 / 26$ & $09: 53: 18.25$ & 39.466 & -118.510 & $5 \cdot 1$ & 32 \\
\hline $1956 / 11 / 16$ & $08: 26: 11.39$ & 41.084 & -116.380 & $4 \cdot 7$ & 50 \\
\hline $1936 / 12 / 31$ & $17: 37: 46.34$ & 38.276 & -118.842 & $3 \cdot 0$ & 43 \\
\hline $1956 / 12 / 31$ & $17: 39: 27.82$ & 38.217 & -118.717 & $5 \cdot 1$ & 22 \\
\hline $1957 / 06 / 11$ & $16: 58: 02.80$ & 38.889 & -118.363 & $4 \cdot 2$ & 36 \\
\hline $1957 / 10 / 17$ & $10: 14: 17 \cdot 37$ & 39.174 & -119.008 & $4 \cdot 6$ & 32 \\
\hline $\begin{array}{l}1958 / 01 / 04 \\
1958 / 01 / 18\end{array}$ & $\begin{array}{l}17: 27: 33: 99 \\
16: 33: 38.65\end{array}$ & $\begin{array}{l}40.035 \\
39.317\end{array}$ & 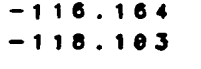 & $\begin{array}{l}4.6 \\
4.4\end{array}$ & $\begin{array}{l}42 \\
41\end{array}$ \\
\hline $1958 / 04 / 02$ & $21: 54: 50.00$ & 37.732 & -118.324 & $4 \cdot 2$ & 35 \\
\hline $1959 / 01 / 05$ & $12: 36: 02 \cdot 22$ & 36.075 & -118.024 & 4.7 & 11 \\
\hline $1959 / 03 / 10$ & $14: 20: 38 \cdot 41$ & 38.642 & -118.542 & $4 \cdot 3$ & 60 \\
\hline $1059 / 03 / 22$ & $10: 47: 33.04$ & 39.256 & -118.100 & 3.9 & 30 \\
\hline $1959 / 03 / 23$ & $07: 10: 23.73$ & 39.546 & -118.135 & $6 \cdot 3$ & 59 \\
\hline $1059 / 03 / 23$ & $11: 49: 26.63$ & 39.520 & -118.172 & $4 \cdot 2$ & 51 \\
\hline $1959 / 03 / 27$ & $11: 59: 50.79$ & 39.595 & -118.129 & $4 \cdot 2$ & 35 \\
\hline $1059 / 04 / 01$ & $18: 18: 30.65$ & 39.759 & -120.173 & $5 \cdot 6$ & 48 \\
\hline $1959 / 04 / 20$ & $12: 33: 40.43$ & 39.589 & -118.159 & $4 \cdot 1$ & 44 \\
\hline $1959 / 05 / 21$ & $17: 51: 40.89$ & 39.567 & -118.177 & 4.8 & 40 \\
\hline $1959 / 06 / 14$ & $01: 26: 32 \cdot 32$ & 39.675 & -120.500 & $4 \cdot 5$ & 7 \\
\hline $1959 / 06 / 18$ & $00: 29: 42.81$ & 37.533 & -118.623 & $4 \cdot 7$ & 45 \\
\hline $1959 / 06 / 23$ & $06: 25: 35.24$ & 36.187 & -118.016 & 3.8 & 41 \\
\hline $1959 / 06 / 23$ & $14: 32: 36.89$ & 39.133 & -118.804 & $4 \cdot 4$ & 40 \\
\hline $1959 / 06 / 23$ & $14: 35: 02 \cdot 41$ & 39.068 & -118.878 & $6 \cdot 1$ & 48 \\
\hline $1959 / 06 / 23$ & $15: 03: 44 \cdot 10$ & 39.347 & -118.461 & 3.9 & 18 \\
\hline $1959 / 06 / 23$ & $15: 04: 35.03$ & 39.058 & -118.916 & $5 \cdot 5$ & 45 \\
\hline $1959 / 86 / 23$ & $15: 22: 46.88$ & 38.933 & -118.948 & $4 \cdot 2$ & 30 \\
\hline $1959 / 08 / 02$ & $22: 16: 44.55$ & 39.496 & -118.268 & $4 \cdot 4$ & 32 \\
\hline $1959 / 08 / 04$ & $07: 36: 59.01$ & 37.382 & -118.550 & $5 \cdot 2$ & 43 \\
\hline $1059 / 08 / 04$ & $07: 40: 30.00$ & 37.514 & $-118 \cdot 443$ & $4 \cdot 2$ & 29 \\
\hline $1950 / 12 / 24$ & $11: 24: 24.14$ & 38.904 & -117.905 & $4 \cdot 2$ & 37 \\
\hline $\begin{array}{l}1960 / 01 / 26 \\
1960 / 03 / 29\end{array}$ & $\begin{array}{l}04: 17: 19.40 \\
03: 31: 15.00\end{array}$ & $\begin{array}{l}36.654 \\
38.400\end{array}$ & $\begin{array}{r}-115.946 \\
-119.332\end{array}$ & $\begin{array}{l}4.9 \\
4.0\end{array}$ & $\begin{array}{l}37 \\
38\end{array}$ \\
\hline
\end{tabular}




\begin{tabular}{|c|c|c|c|c|c|}
\hline DATE (UTC) & $O R|G| N$ & LATITUDE & LONGITUDE & $M A G$ & NOR \\
\hline $1960 / 03 / 29$ & $04: 02: 00.64$ & 38.399 & -119.306 & 4.2 & 34 \\
\hline $1960 / 04 / 09$ & $04: 37: 55.50$ & 38.353 & -119.365 & 4.0 & 32 \\
\hline $1960 / 06 / 05$ & $07: 47: 07.08$ & 37.477 & -118.711 & $5 \cdot 2$ & 52 \\
\hline $1960 / 07 / 01$ & $22: 13: 42.46$ & 35.079 & -117.033 & 4.5 & 8 \\
\hline $1960 / 11 / 18$ & $11: 03: 16.34$ & 39.539 & -120.533 & $4 \cdot 4$ & 21 \\
\hline $1961 / 02 / 02$ & $00: 04: 16.69$ & 37.422 & -118.517 & $5 \cdot 3$ & 43 \\
\hline $1961 / 02 / 02$ & $00: 07: 43.31$ & 37.443 & -118.563 & $5 \cdot 1$ & 33 \\
\hline $1961 / 03 / 27$ & $09: 00: 38.95$ & 36.743 & -116.178 & $4 \cdot 4$ & 46 \\
\hline $1961 / 07 / 04$ & $04: 55: 59.25$ & 48.983 & -118.110 & 5.5 & 43 \\
\hline $1961 / 07 / 04$ & $11: 09: 05.79$ & 40.948 & -118.130 & $5 \cdot 2$ & 40 \\
\hline $1961 / 08 / 04$ & $16: 56: 04.63$ & 39.221 & -118.094 & 4.5 & 40 \\
\hline $1961 / 10 / 19$ & $05: 09: 44.71$ & 35.864 & -117.891 & $5 \cdot 2$ & 21 \\
\hline $1961 / 11 / 18$ & $03: 18: 35.17$ & 35.362 & -117.757 & $4 \cdot 3$ & 15 \\
\hline $1962 / 01 / 31$ & $04: 07: 42.93$ & 38.853 & -117.710 & 4.0 & 26 \\
\hline $1962 / 04 / 05$ & $21: 27: 52.59$ & 38.306 & -119.287 & $4 \cdot 1$ & 42 \\
\hline $1962 / 04 / 13$ & $15: 38: 48 \cdot 42$ & 38.345 & -119.231 & $5 \cdot 1$ & 46 \\
\hline $1962 / 04 / 13$ & $20: 21: 04.73$ & 38.335 & -119.245 & $4 \cdot 2$ & 52 \\
\hline $1962 / 04 / 25$ & $08: 48: 55.93$ & 38.508 & -118.077 & 4.6 & 51 \\
\hline $1962 / 06 / 08$ & $06: 28: 04.26$ & 38.350 & -119.322 & $4 \cdot 2$ & 45 \\
\hline $1962 / 07 / 20$ & $09: 02: 07.10$ & 39.688 & -118.165 & 4.7 & 52 \\
\hline $1962 / 10 / 02$ & $03: 51: 06.97$ & 39.192 & -119.604 & $4 \cdot 3$ & 47 \\
\hline $1962 / 12 / 15$ & $06: 34: 56.03$ & 40.675 & -117.535 & 4.9 & 41 \\
\hline $1963 / 03 / 25$ & $09: 28: 42.77$ & 36.018 & -114.771 & $4 \cdot 9$ & 29 \\
\hline $1963 / 10 / 25$ & $15: 05: 22.64$ & 35.418 & -116.864 & 4.0 & 18 \\
\hline $1964 / 01 / 01$ & $19: 17: 27.88$ & 39.411 & -118.041 & 0.0 & 10 \\
\hline $1964 / 01 / 12$ & $11: 06: 02.74$ & 38.987 & -118.024 & 0.0 & 6 \\
\hline $1964 / 01 / 30$ & $16: 00: 01.80$ & $37 \cdot 126$ & -116.130 & e. 0 & 11 \\
\hline $1964 / 02 / 06$ & $16: 17: 49.54$ & 37.303 & -116.247 & 0.0 & 5 \\
\hline $1964 / 02 / 12$ & $15: 37: 59.52$ & 37.830 & -116.121 & 0.0 & 6 \\
\hline $1964 / 02 / 13$ & $15: 30: 02.10$ & 37.142 & -115.985 & e. 0 & 16 \\
\hline $1964 / 02 / 15$ & $15: 47: 09.13$ & 36.986 & -117.949 & 3.5 & 7 \\
\hline $1964 / 02 / 15$ & $15: 47: 08.27$ & 36.980 & -118.041 & 3.5 & 6 \\
\hline $1964 / 02 / 18$ & $15: 51: 46.77$ & 36.965 & -115.961 & 0.0 & 12 \\
\hline $1964 / 02 / 18$ & $15: 37: 20.60$ & 37.045 & -116.007 & 4.7 & 17 \\
\hline $1964 / 02 / 18$ & $15: 51: 43.80$ & 36.955 & -116.324 & 0.0 & 8 \\
\hline $1964 / 02 / 22$ & $12: 44: 19.13$ & 36.634 & -116.401 & 0.0 & 3 \\
\hline $1964 / 02 / 25$ & $18: 40: 25.41$ & 36.953 & -116.466 & 0.0 & 6 \\
\hline $1964 / 03 / 09$ & $02: 06: 31.32$ & 37.517 & -118.408 & 4.0 & 17 \\
\hline $1964 / 03 / 12$ & $15: 00: 02.70$ & 37.076 & -115.940 & 0.0 & 10 \\
\hline $1964 / 03 / 14$ & $17: 42: 24.78$ & 37.585 & -118.647 & 3.7 & 14 \\
\hline $1964 / 03 / 15$ & $03: 13: 14.18$ & 39.501 & -118.090 & 0.0 & 8 \\
\hline $1964 / 03 / 22$ & $15: 56: 20.99$ & 38.852 & -118.759 & 3.8 & 17 \\
\hline $1964 / 03 / 22$ & $16: 39: 51.47$ & 38.791 & -118.844 & 3.5 & 10 \\
\hline $1964 / 03 / 22$ & $18: 14: 51.70$ & 38.857 & -118.599 & $3 \cdot 5$ & 12 \\
\hline $1964 / 03 / 22$ & $18: 17: 44.07$ & 38.897 & -118.656 & 3.5 & 10 \\
\hline $1964 / 03 / 23$ & $15: 32: 55.65$ & 38.673 & -118.798 & 3.9 & 16 \\
\hline $1964 / 03 / 24$ & $23: 57: 08.56$ & 38.697 & -118.714 & $3 \cdot 5$ & 9 \\
\hline $1964 / 03 / 28$ & $03: 33: 46.83$ & 35.824 & -114.919 & 0.0 & 8 \\
\hline $1964 / 04 / 07$ & $19: 09: 01.66$ & 38.526 & -119.093 & $3 \cdot 5$ & 12 \\
\hline $1964 / 04 / 09$ & $18: 43: 19.38$ & 38.698 & -118.737 & $3 \cdot 7$ & 12 \\
\hline $1964 / 04 / 10$ & $21: 29: 57.09$ & 39.166 & -114.131 & 0. 0 & 7 \\
\hline $1964 / 04 / 11$ & $03: 25: 07.09$ & 38.719 & -118.638 & $3 \cdot 2$ & 9 \\
\hline $1964 / 04 / 12$ & $13: 11: 01.62$ & 39.062 & -118.901 & 3.9 & 13 \\
\hline $1964 / 04 / 16$ & $08: 03: 20.06$ & 36.181 & -114.658 & 0.0 & 11 \\
\hline $1964 / 04 / 25$ & $07: 20: 13.01$ & 37.080 & -116.053 & 4.9 & 17 \\
\hline $1964 / 05 / 07$ & $02: 23: 17.71$ & 37.723 & -118.640 & $3 \cdot 5$ & 9 \\
\hline $1964 / 05 / 09$ & $21: 53: 58.80$ & 37.986 & -118.478 & $3 \cdot 0$ & 8 \\
\hline $1964 / 05 / 29$ & $01: 11: 07.78$ & 37.343 & -114.595 & $3 \cdot 6$ & 9 \\
\hline $\begin{array}{l}1964 / 05 / 30 \\
1964 / 06 / 12\end{array}$ & $\begin{array}{l}18: 35: 51.16 \\
14: 01: 01.44\end{array}$ & $\begin{array}{l}37.179 \\
37.026\end{array}$ & $\begin{array}{l}-115.563 \\
-116.037\end{array}$ & $\begin{array}{l}0.0 \\
0.0\end{array}$ & $\begin{array}{l}6 \\
9\end{array}$ \\
\hline
\end{tabular}




\begin{tabular}{|c|c|c|c|c|c|}
\hline$(U \backslash C)$ & $O R \backslash G$ IN & LATITUDE & LONGITUDE & MAG & NOF \\
\hline $1964 / 06 / 12$ & $14: 01: 01: 44$ & 37.026 & -116.037 & 0.0 & \\
\hline $1064 / 06 / 15$ & $12: 01: 31.63$ & 37.456 & -114.656 & 0. 0 & $\mathbf{1}$ \\
\hline $1064 / 06 / 10$ & $13: 30: 01.05$ & 37.181 & -116.114 & 0.0 & 11 \\
\hline $1964 / 07 / 08$ & $05: 55: 44.18$ & 38.533 & -118.308 & 4.4 & 22 \\
\hline $1964 / 08 / 02$ & $13: 20: 07.57$ & 39.179 & -118.094 & 4.0 & 1 \\
\hline $1064 / 08 / 04$ & $07: 22: 51.16$ & 39.108 & -118.143 & 3.6 & 1 \\
\hline $1064 / 00 / 04$ & $20: 20: 24.45$ & 37.492 & -118.560 & $4 \cdot 1$ & \\
\hline $1064 / 00 / 16$ & $05: 34: 29.22$ & 37.114 & -114.910 & 0.0 & \\
\hline $1064 / 00 / 23$ & $18: 09: 38.84$ & 35.940 & -114.820 & 4.4 & \\
\hline $1064 / 00 / 24$ & $12: 51: 33 \cdot 15$ & 38.171 & -118.505 & 3.5 & 1 \\
\hline $1064 / 10 / 07$ & $07: 37: 09.07$ & 30.027 & -118.010 & $3 \cdot 4$ & \\
\hline $1064 / 10 / 00$ & $07: 55: 38.79$ & 38.771 & -119.347 & $3 \cdot 6$ & 1 \\
\hline $064 / 10 / 00$ & $22: 52: 03.29$ & 38.398 & -118.283 & 0.0 & \\
\hline $1064 / 10 / 11$ & $01: 00: 46.67$ & 38.439 & -118.236 & B. 0 & \\
\hline $1964 / 10 / 13$ & $13: 29: 17.94$ & 39.555 & -118.173 & 0.0 & \\
\hline $1964 / 10 / 16$ & $16: 09: 40.43$ & 35.939 & -117.275 & 0.0 & \\
\hline $1064 / 10 / 23$ & $13: 57: 09.42$ & 38.559 & -118.382 & $5 \cdot 3$ & 23 \\
\hline $1064 / 10 / 30$ & $17: 44: 56.52$ & 37.992 & -117.838 & 3.5 & \\
\hline $1064 / 10 / 30$ & $17: 50: 45.00$ & 37.600 & -118.050 & $4 \cdot 1$ & 1 \\
\hline $064 / 10 / 30$ & $18: 18: 06.01$ & 37.606 & -118.264 & $3 \cdot 0$ & \\
\hline $064 / 10 / 30$ & $10: 01: 43: 00$ & 37.505 & -117.868 & $3 \cdot 5$ & \\
\hline $1964 / 10 / 30$ & $19: 03: 12.56$ & 37.700 & -118.045 & 4.5 & 14 \\
\hline $1064 / 10 / 30$ & $19: 14: 19.31$ & 37.879 & -118.071 & 0.0 & \\
\hline $064 / 10 / 30$ & $19: 40: 28.75$ & 37.835 & -117.823 & $3 \cdot 5$ & 7 \\
\hline $1064 / 10 / 30$ & $23: 02: 58.60$ & 37.646 & -118.010 & 4.1 & \\
\hline $064 / 10 / 31$ & $11: 57: 23.65$ & 37.544 & -118.249 & $3 \cdot 7$ & 11 \\
\hline $1064 / 10 / 31$ & $18: 41: 22.32$ & 36.733 & -110.720 & 0.0 & 7 \\
\hline $1064 / 10 / 31$ & $10: 35: 20.02$ & 37.823 & -118.175 & 4.0 & 10 \\
\hline $1064 / 10 / 31$ & $21: 37: 27 \cdot 11$ & 38.001 & -117.814 & 0.0 & \\
\hline $1064 / 11 / 01$ & $19: 01: 27.77$ & 37.671 & -118.060 & 3.6 & 10 \\
\hline $1064 / 11 / 01$ & $10: 02: 27.31$ & 37.498 & -117.824 & 0.0 & \\
\hline $1064 / 11 / 01$ & $20: 40: 57.60$ & 37.498 & -118.120 & 3.9 & 11 \\
\hline $1964 / 11 / 02$ & $06: 55: 48.30$ & 37.648 & -118.160 & 0.0 & 6 \\
\hline $1064 / 11 / 02$ & $11: 38: 33.43$ & 37.593 & -117.981 & $4 \cdot 4$ & 21 \\
\hline $1064 / 11 / 02$ & $14: 04: 39.50$ & 38.012 & -117.731 & 0.0 & - \\
\hline $1064 / 11 / 03$ & $04: 48: 51.79$ & 37.579 & -118.024 & 0.0 & 8 \\
\hline $1064 / 11 / 03$ & $18: 58: 42.23$ & 37.606 & -117.953 & $3 \cdot 5$ & 15 \\
\hline $1064 / 11 / 04$ & $11: 50: 28.62$ & 37.632 & -118.060 & 3.5 & 19 \\
\hline $1064 / 11 / 04$ & $11: 53: 49.77$ & 37.474 & -117.937 & 3.0 & 13 \\
\hline $1064 / 11 / 12$ & $04: 33: 43.11$ & 39.215 & -118.614 & 0.0 & 6 \\
\hline $1964 / 11 / 12$ & $20: 07: 24.80$ & 37.675 & -118.003 & 4.0 & 15 \\
\hline $1964 / 11 / 13$ & $05: 05: 09.91$ & 37.600 & -118.023 & $4 \cdot 1$ & 22 \\
\hline $1964 / 11 / 23$ & $23: 52: 10.91$ & 37.614 & -117.973 & 0.0 & \\
\hline $1064 / 11 / 23$ & $23: 52: 31.26$ & 37.388 & -118.011 & $4 \cdot 4$ & 22 \\
\hline $1064 / 12 / 01$ & $15: 28: 10.60$ & 37.883 & -117.800 & $3 \cdot 7$ & 8 \\
\hline $1964 / 12 / 02$ & $00: 17: 47.39$ & 37.526 & -117.979 & 3.5 & 17 \\
\hline $1064 / 12 / 02$ & $23: 43: 42.05$ & 37.938 & -117.091 & 0.0 & 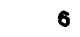 \\
\hline $1064 / 12 / 05$ & $14: 11: 23.64$ & 38.051 & -117.797 & 0.0 & \\
\hline $1964 / 12 / 07$ & $16: 20: 33: 90$ & 36.678 & -117.174 & 0.0 & \\
\hline $1964 / 12 / 11$ & $19: 21: 49.39$ & 38.797 & $-118 \cdot 356$ & 4.2 & 7 \\
\hline $1964 / 12 / 12$ & $07: 59: 18.76$ & 39.257 & $-118 \cdot 143$ & $3 \cdot 4$ & 12 \\
\hline $1064 / 12 / 12$ & $12: 40: 06.11$ & 30.509 & -119.432 & 0.0 & \\
\hline $1064 / 12 / 12$ & $13: 32: 01.43$ & 39.383 & -119.518 & $4 \cdot 1$ & 8 \\
\hline $1964 / 12 / 14$ & $08: 15: 40.03$ & 37.980 & -117.824 & 3.5 & \\
\hline $1964 / 12 / 20$ & $21: 56: 03.84$ & 35.914 & -114.881 & 3.6 & \\
\hline $1964 / 12 / 23$ & $18: 42: 44.20$ & 37.390 & -115.112 & 0.0 & \\
\hline $1964 / 12 / 31$ & $10: 41: 04.25$ & 35.034 & -116.663 & 3.9 & \\
\hline $1065 / 01 / 12$ & $01: 37: 53.74$ & 37.356 & -117.502 & 0.0 & \\
\hline $1065 / 01 / 13$ & $03: 51: 13.79$ & 38.098 & -119.110 & $3 \cdot 7$ & \\
\hline $1065 / 01 / 19$ & $00: 38: 25.51$ & 38.073 & -119.125 & $3 \cdot 1$ & \\
\hline
\end{tabular}




\begin{tabular}{|c|c|c|c|c|c|}
\hline DATE (UTC) & $O R I G I N$ & LATITUDE & LONGITUDE & MAG & NOR \\
\hline $1965 / 01 / 21$ & $07: 05: 52.36$ & 37.888 & -117.962 & B. 0 & 6 \\
\hline $1965 / 01 / 22$ & $10: 24: 38.64$ & 37.418 & -118.321 & $3 \cdot 5$ & 7 \\
\hline $1965 / 01 / 29$ & $18: 22: 01.58$ & 37.827 & -116.053 & 0. 0 & 14 \\
\hline $1965 / 02 / 11$ & $01: 35: 58.84$ & 37.091 & -117.859 & 3.5 & 13 \\
\hline $1965 / 02 / 16$ & $17: 49: 20.64$ & 37.048 & -116.142 & 0.0 & 10 \\
\hline $1965 / 02 / 21$ & $17: 21: 57 \cdot 18$ & 37.472 & -119.405 & $3 \cdot 1$ & 5 \\
\hline $1965 / 03 / 08$ & $22: 50: 55.01$ & 38.658 & -118.752 & $4 \cdot 1$ & 15 \\
\hline $1965 / 03 / 26$ & $18: 29: 40.17$ & 36.715 & -116.064 & 0.0 & 10 \\
\hline $1965 / 03 / 30$ & $09: 45: 02.02$ & 37.436 & -118.690 & $3 \cdot 0$ & 8 \\
\hline $1965 / 04 / 06$ & $15: 57: 02.65$ & 38.889 & -118.669 & 3.7 & 12 \\
\hline $1965 / 04 / 12$ & $08: 41: 39.88$ & 36.366 & -117.795 & 3.0 & 8 \\
\hline $1965 / 04 / 13$ & $13: 14: 15.85$ & 39.106 & -118.098 & 4.6 & 15 \\
\hline $1965 / 04 / 21$ & $22: 87: 23: 34$ & 37.062 & -116.211 & 0.0 & 7 \\
\hline $1965 / 04 / 22$ & $13: 39: 81.82$ & 37.080 & -116.065 & B. 0 & 11 \\
\hline $1965 / 05 / 03$ & $03: 30: 50.94$ & 35.988 & -114.750 & 4.2 & 13 \\
\hline $1965 / 05 / 10$ & $23: 33: 40.91$ & 39.487 & -118.785 & B. 0 & 6 \\
\hline $1965 / 05 / 13$ & $20: 52: 37.61$ & 41.022 & -115.936 & B. 0 & 5 \\
\hline $1965 / 05 / 14$ & $14: 57: 52.84$ & 38.795 & -115.907 & B. 8 & 10 \\
\hline $1965 / 05 / 14$ & $14: 57: 52.85$ & 36.790 & -115.906 & B. 0 & 10 \\
\hline $1965 / 05 / 15$ & $06: 25: 02.68$ & 35.947 & -114.774 & 3.8 & 14 \\
\hline $1965 / 05 / 19$ & $11: 50: 39.13$ & 38.333 & -115.918 & 0.0 & 7 \\
\hline $1965 / 05 / 21$ & $06: 51: 36.46$ & 39.467 & -118.183 & 3.2 & 9 \\
\hline $1965 / 05 / 21$ & $17: 50: 33.27$ & 37.854 & -117.785 & e. 0 & 7 \\
\hline $1965 / 05 / 25$ & $00: 48: 11.43$ & 37.109 & -117.228 & 4.0 & 11 \\
\hline $1965 / 05 / 28$ & $08: 18: 49.83$ & 37.626 & -117.329 & 3.8 & 9 \\
\hline $1965 / 06 / 02$ & $20: 46: 57.84$ & 39.398 & -118.459 & 3.8 & 12 \\
\hline $1965 / 06 / 03$ & $16: 26: 26.89$ & 38.340 & -119.178 & 4.8 & 22 \\
\hline $1965 / 86 / 03$ & $16: 31: 01.61$ & 38.379 & -119.204 & 4.9 & 18 \\
\hline $1965 / 06 / 10$ & $17: 36: 24.14$ & 37.983 & -119.190 & $3 \cdot 3$ & 7 \\
\hline $1965 / 06 / 18$ & $08: 14: 01.04$ & 37.286 & -116.059 & $3 \cdot 3$ & 7 \\
\hline $1965 / 06 / 25$ & $00: 18: 56.33$ & 39.125 & -118.072 & 4.4 & 15 \\
\hline $1965 / 09 / 22$ & $21: 49: 25.78$ & 37.403 & -118.567 & 4.5 & 21 \\
\hline $1965 / 11 / 01$ & $17: 10: 14.66$ & 39.261 & -118.517 & 4.3 & 18 \\
\hline $1966 / 01 / 08$ & $11: 03: 59.82$ & 38.799 & -117.883 & $3 \cdot 5$ & 9 \\
\hline $1966 / 01 / 08$ & $11: 03: 59.41$ & 38.830 & -117.908 & 3.5 & 9 \\
\hline $1966 / 01 / 10$ & $82: 48: 37.91$ & 38.659 & -119.743 & $3 \cdot 1$ & 6 \\
\hline $1966 / 01 / 13$ & $03: 40: 39.01$ & 36.080 & -117.865 & $3 \cdot 1$ & 16 \\
\hline $1966 / 81 / 13$ & $03: 46: 37.78$ & 36.101 & -117.890 & $2 \cdot 7$ & 11 \\
\hline $1966 / 01 / 13$ & $03: 40: 38 \cdot 98$ & 36.079 & -117.868 & $3 \cdot 1$ & 16 \\
\hline $1966 / 01 / 13$ & $03: 46: 37.71$ & 36.101 & -117.890 & $2 \cdot 7$ & 11 \\
\hline $1966 / 01 / 16$ & $14: 44: 38 \cdot 32$ & 35.373 & -117.700 & 3.3 & 19 \\
\hline $1966 / 01 / 18$ & $07: 41: 55.78$ & 36.598 & -118.185 & 3.0 & 9 \\
\hline $1966 / 01 / 22$ & $13: 50: 37: 91$ & 40.978 & -118.419 & 3.6 & 7 \\
\hline $1966 / 02 / 06$ & $05: 03: 24.20$ & 38.879 & -118.519 & 3.8 & 17 \\
\hline $1966 / 02 / 87$ & $17: 55: 36.81$ & 36.613 & -117.898 & 3.4 & 6 \\
\hline $1966 / 82 / 87$ & $17: 55: 36.33$ & 36.577 & -117.852 & $3 \cdot 4$ & 6 \\
\hline $1966 / 82 / 14$ & $20: 59: 02.07$ & 37.581 & -118.693 & $3 \cdot 3$ & 6 \\
\hline $1966 / 02 / 23$ & $13: 48: 33 \cdot 48$ & 38.597 & -116.826 & 3.6 & 8 \\
\hline $1966 / 02 / 23$ & $13: 40: 34.17$ & 38.571 & -116.115 & $3 \cdot 6$ & 10 \\
\hline $1966 / 04 / 02$ & $12: 48: 39.25$ & 38.468 & -118.180 & 4.8 & 28 \\
\hline $1966 / 04 / 82$ & $15: 40: 40.92$ & 37.495 & $-118 \cdot 485$ & $3 \cdot 3$ & 5 \\
\hline $1966 / 04 / 06$ & $17: 56: 30.27$ & 37.293 & -115.358 & 4. 1 & 13 \\
\hline $1966 / 04 / 87$ & $11: 00: 54.19$ & 38.729 & -119.414 & $3 \cdot 7$ & 12 \\
\hline $1966 / 04 / 08$ & $02: 54: 57.78$ & 37.263 & $-115 \cdot 433$ & 0.0 & 10 \\
\hline $1966 / 04 / 17$ & $07: 04: 18.61$ & 37.356 & $-118 \cdot 547$ & 4.0 & 20 \\
\hline $1966 / 04 / 18$ & $06: 49: 25.99$ & 36.299 & -118.662 & $3 \cdot 5$ & 8 \\
\hline $1966 / 04 / 29$ & $10: 01: 44.41$ & 37.613 & -118.858 & $3 \cdot 5$ & 22 \\
\hline $1966 / 05 / 20$ & $07: 31: 09 \cdot 37$ & 36.855 & -117.377 & $3 \cdot 5$ & 20 \\
\hline $1966 / 05 / 20$ & $07: 31: 09.37$ & 36.055 & -117.377 & $3 \cdot 5$ & 19 \\
\hline $1966 / 05 / 30$ & $09: 39: 01.07$ & 38.095 & -118.294 & $3 \cdot 5$ & 9 \\
\hline
\end{tabular}




\begin{tabular}{|c|c|c|c|c|c|}
\hline ( U T C ) & OR I G I N & LATITUDE & LONGITUDE & $\mathbf{M A G}$ & NOR \\
\hline $1060 / 06 / 01$ & $12: 28: 18.31$ & 37.639 & -117.746 & $3 \cdot 2$ & 6 \\
\hline $1060 / 06 / 03$ & $01: 52: 36.56$ & 38.581 & -119.602 & 3.0 & 7 \\
\hline $1060 / 06 / 20$ & $18: 45: 43.59$ & 38.254 & -118.336 & 3.4 & 10 \\
\hline $1066 / 06 / 20$ & $19: 58: 50.13$ & 38.232 & -118.311 & $3 \cdot 4$ & 10 \\
\hline $1066 / 06 / 21$ & $05: 55: 01.32$ & 38.334 & -118.337 & $3 \cdot 1$ & 10 \\
\hline $1066 / 06 / 27$ & $07: 40: 17.55$ & 38.794 & -110.350 & 3.6 & 15 \\
\hline $1966 / 07 / 10$ & $00: 41: 10.10$ & 37.503 & -118.329 & 3.2 & 10 \\
\hline $1966 / 07 / 15$ & $10: 80: 41.77$ & 35.152 & -117.762 & 4.0 & 15 \\
\hline $1066 / 07 / 28$ & $02: 40: 50.03$ & 37.001 & -118.026 & 2.7 & 6 \\
\hline $1966 / 08 / 16$ & $18: 02: 33.80$ & 37.395 & -114.143 & 6.0 & 28 \\
\hline $1066 / 08 / 16$ & $10: 50: 07.65$ & 37.402 & -114.173 & 4.5 & 17 \\
\hline $1066 / 08 / 16$ & $20: 11: 31.82$ & 37.320 & -114.231 & 0.0 & 7 \\
\hline $1966 / 08 / 16$ & $20: 34: 46.07$ & 37.320 & -114.157 & 0.0 & 8 \\
\hline $1966 / 08 / 16$ & $20: 42: 25.63$ & 37.373 & -114.192 & 0.0 & 10 \\
\hline $1066 / 08 / 17$ & $01: 04: 11.05$ & 37.436 & -114.006 & 0.0 & 8 \\
\hline $1006 / 08 / 17$ & $02: 37: 00.36$ & 37.383 & -114.080 & 0.0 & 8 \\
\hline $1066 / 08 / 17$ & $03: 06: 51.10$ & 37.286 & -114.151 & 0.0 & 9 \\
\hline $1066 / 08 / 17$ & $03: 14: 00.30$ & 37.065 & -113.882 & 0.0 & 8 \\
\hline $1966 / 08 / 17$ & $04: 13: 50.80$ & 37.387 & -114.131 & 4.4 & 16 \\
\hline $1966 / 08 / 17$ & $04: 46: 39.26$ & 37.339 & -114.167 & 4.0 & 14 \\
\hline $1966 / 88 / 17$ & $05: 08: 21.30$ & 37.337 & -114.130 & 0.0 & 7 \\
\hline $1966 / 08 / 17$ & $11: 19: 03.80$ & 37.400 & -114.028 & 0.0 & 7 \\
\hline $1066 / 08 / 17$ & $11: 32: 37.74$ & 37.374 & -114.050 & 0.0 & 8 \\
\hline $1966 / 08 / 17$ & $13: 06: 55.77$ & 37.450 & -114.109 & 0.0 & 9 \\
\hline $1966 / 08 / 17$ & $14: 20: 54.05$ & 37.393 & -114.108 & 3.7 & 8 \\
\hline $1966 / 08 / 17$ & $19: 14: 55.78$ & 37.357 & -114.142 & 0.0 & 10 \\
\hline $1966 / 08 / 17$ & $21: 42: 49.38$ & 37.413 & -114.108 & 3.6 & 11 \\
\hline $1966 / 08 / 17$ & $23: 07: 57.46$ & 37.395 & -114.053 & 4.8 & 24 \\
\hline $1966 / 08 / 17$ & $23: 27: 18.12$ & 37.390 & -114.132 & 0.0 & 6 \\
\hline $1066 / 08 / 18$ & $06: 14: 59.58$ & 37.360 & -114.185 & 4.5 & 22 \\
\hline $1066 / 08 / 18$ & $06: 27: 41.76$ & 37.356 & -114.183 & 3.5 & 13 \\
\hline $1960 / 08 / 18$ & $06: 40: 33.85$ & 37.417 & -113.995 & 0.0 & 7 \\
\hline $1966 / 08 / 18$ & $07: 17: 07.57$ & 37.365 & -114.173 & 0.0 & 7 \\
\hline $1966 / 08 / 18$ & $07: 32: 08.48$ & 37.377 & -114.082 & $\theta .0$ & 8 \\
\hline $1066 / 08 / 18$ & $08: 03: 34.05$ & 37.189 & -114.264 & 3.0 & 6 \\
\hline $1966 / 08 / 18$ & $08: 07: 56.14$ & 37.304 & -114.141 & 0.0 & 10 \\
\hline $1066 / 88 / 18$ & $00: 15: 35.49$ & 37.349 & -114.151 & 5.0 & 24 \\
\hline $1966 / 08 / 18$ & $09: 28: 53.00$ & 37.445 & -113.991 & 3.8 & 10 \\
\hline $1966 / 08 / 18$ & $10: 00: 20.50$ & 37.265 & -114.268 & 3.9 & 15 \\
\hline $1066 / 88 / 18$ & $10: 28: 00.39$ & 37.377 & -114.102 & 0.0 & 7 \\
\hline $1066 / 08 / 18$ & $10: 43: 32.70$ & 37.383 & -113.987 & 0.0 & 10 \\
\hline $1066 / 08 / 18$ & $11: 31: 52.87$ & 37.153 & -114.243 & 0.0 & 5 \\
\hline $1066 / 08 / 18$ & $12: 00: 33.26$ & 37.295 & -114.232 & 4.5 & 21 \\
\hline $1066 / 08 / 18$ & $13: 26: 46.96$ & 37.346 & -114.342 & 0.0 & 4 \\
\hline $1966 / 08 / 18$ & $13: 33: 10.50$ & 37.334 & -114.178 & 4.5 & 20 \\
\hline $1066 / 08 / 18$ & $17: 35: 05.12$ & 37.334 & -114.177 & 5.0 & 24 \\
\hline $1066 / 08 / 18$ & $19: 57: 34.65$ & 37.431 & -114.071 & 0.0 & $\boldsymbol{\theta}$ \\
\hline $1066 / 08 / 18$ & $20: 09: 13.51$ & 37.337 & -114.218 & $3 \cdot 7$ & 9 \\
\hline $1966 / 08 / 18$ & $21: 23: 54.66$ & 37.308 & -114.130 & 0.0 & 6 \\
\hline $1066 / 08 / 18$ & $21: 56: 07.91$ & 37.305 & -114.283 & 0.0 & 8 \\
\hline $1066 / 08 / 10$ & $00: 18: 54.34$ & 37.367 & -114.297 & $4 \cdot 3$ & 11 \\
\hline $1066 / 08 / 19$ & $01: 27: 14.34$ & 37.302 & -114.270 & 0.0 & 6 \\
\hline $1066 / 08 / 10$ & $02: 08: 03.58$ & 37.335 & -114.268 & 3.6 & 10 \\
\hline $1066 / 08 / 19$ & $05: 15: 15.11$ & 37.365 & -114.157 & 0.0 & 8 \\
\hline $1966 / 08 / 19$ & $05: 53: 33.19$ & 37.317 & -114.166 & 0.0 & 8 \\
\hline $1066 / 08 / 10$ & $06: 16: 07.76$ & 37.349 & -114.136 & 0.0 & 8 \\
\hline $1066 / 08 / 10$ & $07: 50: 58.61$ & 37.488 & -114.062 & 0.0 & 7 \\
\hline $1060 / 08 / 10$ & $07: 57: 50.87$ & 37.360 & -114.277 & $\theta .0$ & 4 \\
\hline $\begin{array}{l}1966 / 08 / 10 \\
1966 / 08 / 19\end{array}$ & $\begin{array}{l}00: 21: 06.68 \\
10: 51: 38.79\end{array}$ & $\begin{array}{l}37.335 \\
37.365\end{array}$ & $\begin{array}{l}-114.190 \\
-114.154\end{array}$ & $\begin{array}{l}0.0 \\
4.5\end{array}$ & 22 \\
\hline
\end{tabular}




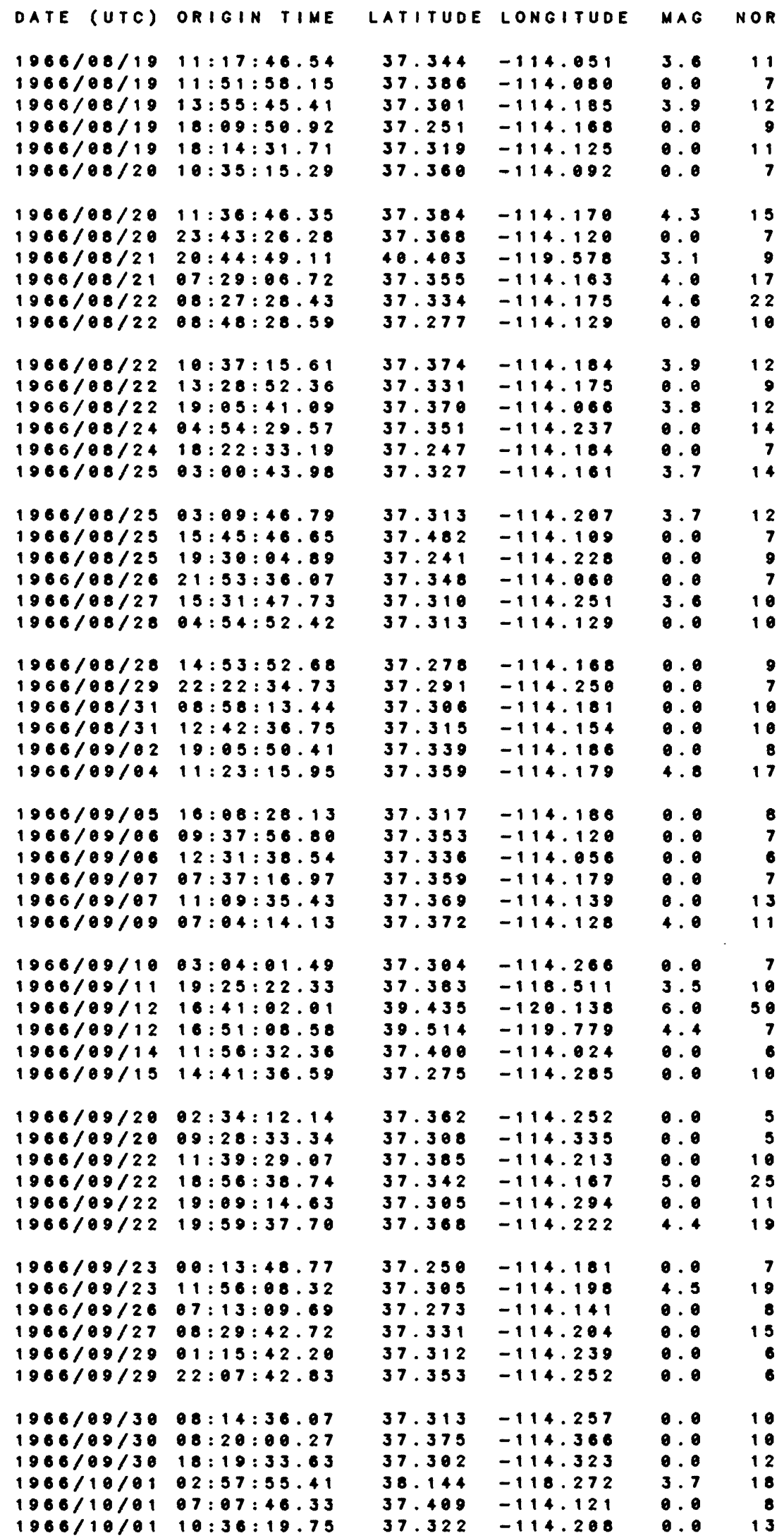




\begin{tabular}{|c|c|c|c|c|}
\hline DATE' (UTC) & ORIGIN TIME & LATITUDE & LONGITUDE & MAG \\
\hline $\begin{array}{l}1967 / 01 / 27 \\
1967 / 02 / 02 \\
1967 / 02 / 13 \\
1967 / 02 / 14 \\
1967 / 02 / 16 \\
1967 / 02 / 16\end{array}$ & $\begin{array}{l}11: 06: 01.23 \\
03: 52: 04.33 \\
08: 05: 59.07 \\
01: 08: 24.97 \\
15: 05: 53.23 \\
16: 27: 08.36\end{array}$ & $\begin{array}{l}37.402 \\
37.386 \\
36.029 \\
37.344 \\
37.392 \\
37.384\end{array}$ & $\begin{array}{l}-114.089 \\
-114.078 \\
-114.682 \\
-116.465 \\
-114.180 \\
-1114.104\end{array}$ & $\begin{array}{l}0.0 \\
0.0 \\
0.0 \\
3.9 \\
4.0 \\
0.0\end{array}$ \\
\hline $\begin{array}{l}1967 / 02 / 25 \\
1967 / 02 / 26 \\
1967 / 03 / 02 \\
1967 / 03 / 05 \\
1967 / 03 / 11 \\
1967 / 03 / 20\end{array}$ & $\begin{array}{l}07: 20: 19.77 \\
13: 52: 56.54 \\
14: 12: 49.56 \\
21: 30: 43.40 \\
15: 53: 56.75 \\
02: 10: 17.37\end{array}$ & $\begin{array}{l}39.282 \\
36.333 \\
36.388 \\
39.212 \\
37.638 \\
37.298\end{array}$ & $\begin{array}{l}-118.198 \\
-114.371 \\
-117.668 \\
-118.100 \\
-118.461 \\
-114.199\end{array}$ & $\begin{array}{l}3.5 \\
0.0 \\
4.4 \\
3.7 \\
3.2 \\
0.0\end{array}$ \\
\hline $\begin{array}{l}1967 / 03 / 28 \\
1967 / 04 / 06 \\
1967 / 04 / 13 \\
1967 / 04 / 26 \\
1967 / 04 / 28 \\
1967 / 06 / 01\end{array}$ & $\begin{array}{l}12: 23: 58.41 \\
01: 05: 46.92 \\
18: 11: 40.91 \\
09: 27: 53.53 \\
12: 57: 40.15 \\
00: 35: 40.14\end{array}$ & $\begin{array}{l}37.406 \\
36.165 \\
38.533 \\
37.253 \\
37.314 \\
37.257\end{array}$ & $\begin{array}{l}-118.510 \\
-110.753 \\
-118.352 \\
-118.108 \\
-118.545 \\
-1116.548\end{array}$ & $\begin{array}{l}3 \cdot 5 \\
3 \cdot 4 \\
3 \cdot 8 \\
3 \cdot 8 \\
3 \cdot 9 \\
3.6\end{array}$ \\
\hline $\begin{array}{l}1967 / 06 / 01 \\
1967 / 06 / 26 \\
1967 / 07 / 00 \\
1967 / 07 / 30 \\
1987 / 08 / 06 \\
1967 / 08 / 08\end{array}$ & $\begin{array}{l}09: 42: 20.95 \\
02: 25: 58.11 \\
15: 41: 40.04 \\
15: 45: 05.14 \\
11: 15: 01.77 \\
17: 52: 11.93\end{array}$ & $\begin{array}{l}37.324 \\
36.121 \\
37.106 \\
39.090 \\
39.524 \\
37.241\end{array}$ & $\begin{array}{l}-116.358 \\
-117.849 \\
-117.891 \\
-118.130 \\
-118.287 \\
-1116.512\end{array}$ & $\begin{array}{l}0 \cdot 0 \\
2 \cdot 9 \\
3 \cdot 5 \\
3 \cdot 1 \\
3 \cdot 3 \\
3 \cdot 2\end{array}$ \\
\hline $\begin{array}{l}1967 / 08 / 09 \\
1967 / 08 / 20 \\
1967 / 08 / 22 \\
1967 / 08 / 23 \\
1967 / 08 / 29 \\
1967 / 09 / 02\end{array}$ & $\begin{array}{l}06: 45: 05.82 \\
06: 14: 06.17 \\
08: 19: 26.59 \\
23: 10: 27.38 \\
19: 40: 03.18 \\
20: 25: 41.40\end{array}$ & $\begin{array}{l}37.242 \\
37.421 \\
37.384 \\
37.589 \\
40.336 \\
37.415\end{array}$ & $\begin{array}{l}-116.530 \\
-118.778 \\
-118.381 \\
-118.323 \\
-119.840 \\
-118.102\end{array}$ & $\begin{array}{l}3 \cdot 9 \\
3 \cdot 1 \\
3 \cdot 8 \\
3 \cdot 4 \\
3 \cdot 5 \\
3 \cdot 5\end{array}$ \\
\hline $\begin{array}{l}1967 / 09 / 08 \\
1967 / 09 / 20 \\
1967 / 09 / 21 \\
1967 / 10 / 02 \\
1967 / 10 / 09 \\
1967 / 10 / 27\end{array}$ & $\begin{array}{l}05: 39: 51.69 \\
04: 51: 21.14 \\
17: 00: 08.52 \\
09: 44: 32.41 \\
17: 01: 11.34 \\
01: 42: 28.12\end{array}$ & $\begin{array}{l}37.209 \\
37.173 \\
36.250 \\
37.241 \\
38.594 \\
37.354\end{array}$ & $\begin{array}{l}-118.486 \\
-115.158 \\
-118.316 \\
-118.684 \\
-119.422 \\
-117.549\end{array}$ & $\begin{array}{l}2 \cdot 9 \\
0 \cdot 0 \\
3 \cdot 3 \\
2 \cdot 4 \\
3 \cdot 3 \\
2 \cdot 7\end{array}$ \\
\hline $\begin{array}{l}1967 / 11 / 01 \\
1967 / 11 / 02 \\
1967 / 11 / 04 \\
1967 / 11 / 06 \\
1967 / 11 / 07 \\
1067 / 11 / 00\end{array}$ & $\begin{array}{l}07: 41: 33.52 \\
17: 56: 30.63 \\
22: 32: 45.17 \\
07: 22: 45.70 \\
03: 44: 33.71 \\
22: 50: 32.80\end{array}$ & $\begin{array}{l}37.397 \\
38.144 \\
38.310 \\
38.388 \\
39.192 \\
37.327\end{array}$ & $\begin{array}{l}-114.095 \\
-118.850 \\
-119.382 \\
-119.426 \\
-118.195 \\
-114.078\end{array}$ & $\begin{array}{l}0.0 \\
2.0 \\
0.0 \\
3.4 \\
3.1 \\
0.0\end{array}$ \\
\hline $\begin{array}{l}1967 / 11 / 11 \\
1967 / 11 / 11 \\
1967 / 11 / 21 \\
1967 / 11 / 21 \\
1967 / 11 / 29 \\
1967 / 12 / 05\end{array}$ & $\begin{array}{l}05: 44: 22.24 \\
05: 51: 52.24 \\
05: 30: 22.75 \\
17: 25: 08.49 \\
17: 29: 03.07 \\
18: 28: 54.73\end{array}$ & $\begin{array}{l}37.572 \\
37.649 \\
37.454 \\
37.198 \\
35.592 \\
38.000\end{array}$ & $\begin{array}{l}-118.598 \\
-118.698 \\
-118.470 \\
-117.370 \\
-117.509 \\
-118.308\end{array}$ & $\begin{array}{l}3 \cdot 1 \\
3 \cdot 9 \\
4 \cdot 4 \\
3 \cdot 3 \\
3 \cdot 3 \\
3 \cdot 5\end{array}$ \\
\hline $\begin{array}{l}1967 / 12 / 00 \\
1967 / 12 / 07 \\
1967 / 12 / 11 \\
1967 / 12 / 20 \\
1967 / 12 / 20 \\
1967 / 12 / 20\end{array}$ & $\begin{array}{l}01: 33: 03.30 \\
16: 41: 20.25 \\
02: 35: 19.39 \\
01: 49: 14.03 \\
02: 27: 26.02 \\
22: 17: 09.91\end{array}$ & $\begin{array}{l}37.058 \\
40.021 \\
37.172 \\
38.568 \\
38.579 \\
37.407\end{array}$ & $\begin{array}{l}-115.296 \\
-118.919 \\
-115.173 \\
-119.485 \\
-119.501 \\
-118.489\end{array}$ & $\begin{array}{l}3 \cdot 7 \\
3 \cdot 8 \\
3 \cdot 3 \\
2 \cdot 8 \\
3 \cdot 4 \\
3 \cdot 3\end{array}$ \\
\hline $\begin{array}{l}1068 / 01 / 01 \\
1960 / 01 / 04 \\
1908 / 01 / 05 \\
1968 / 01 / 14 \\
1908 / 01 / 14 \\
1968 / 01 / 30\end{array}$ & $\begin{array}{l}00: 28: 04.35 \\
09: 45: 43.08 \\
08: 40: 20.83 \\
04: 32: 53.25 \\
04: 34: 10.09 \\
15: 20: 04.48\end{array}$ & $\begin{array}{l}38.207 \\
36.481 \\
37.565 \\
35.270 \\
35.311 \\
41.044\end{array}$ & $\begin{array}{l}-118.084 \\
-117.004 \\
-118.523 \\
-117.886 \\
-117.912 \\
-117.447\end{array}$ & $\begin{array}{l}3 \cdot 2 \\
3 \cdot 6 \\
3 \cdot 0 \\
2 \cdot 9 \\
2 \cdot 8 \\
4.5\end{array}$ \\
\hline
\end{tabular}




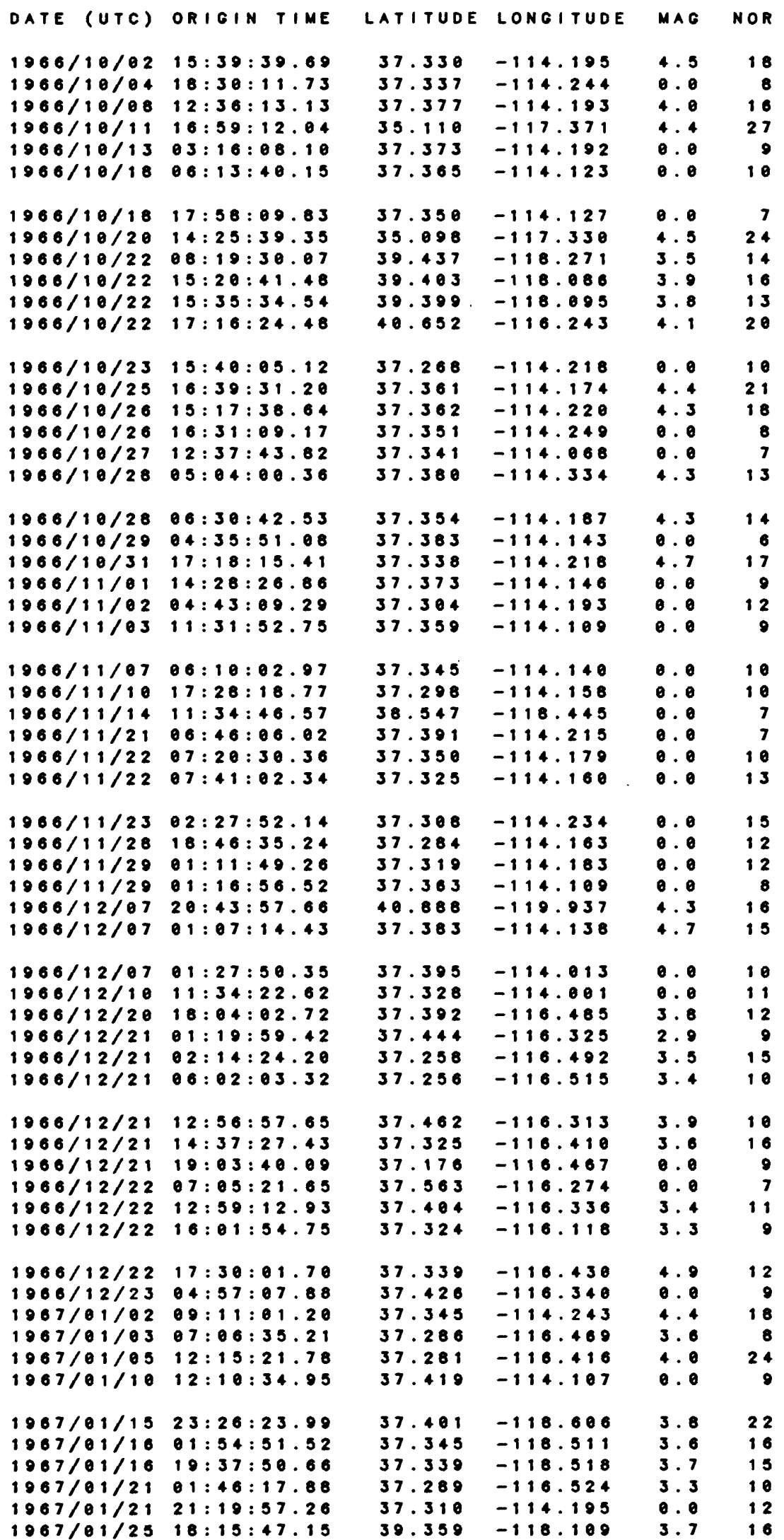




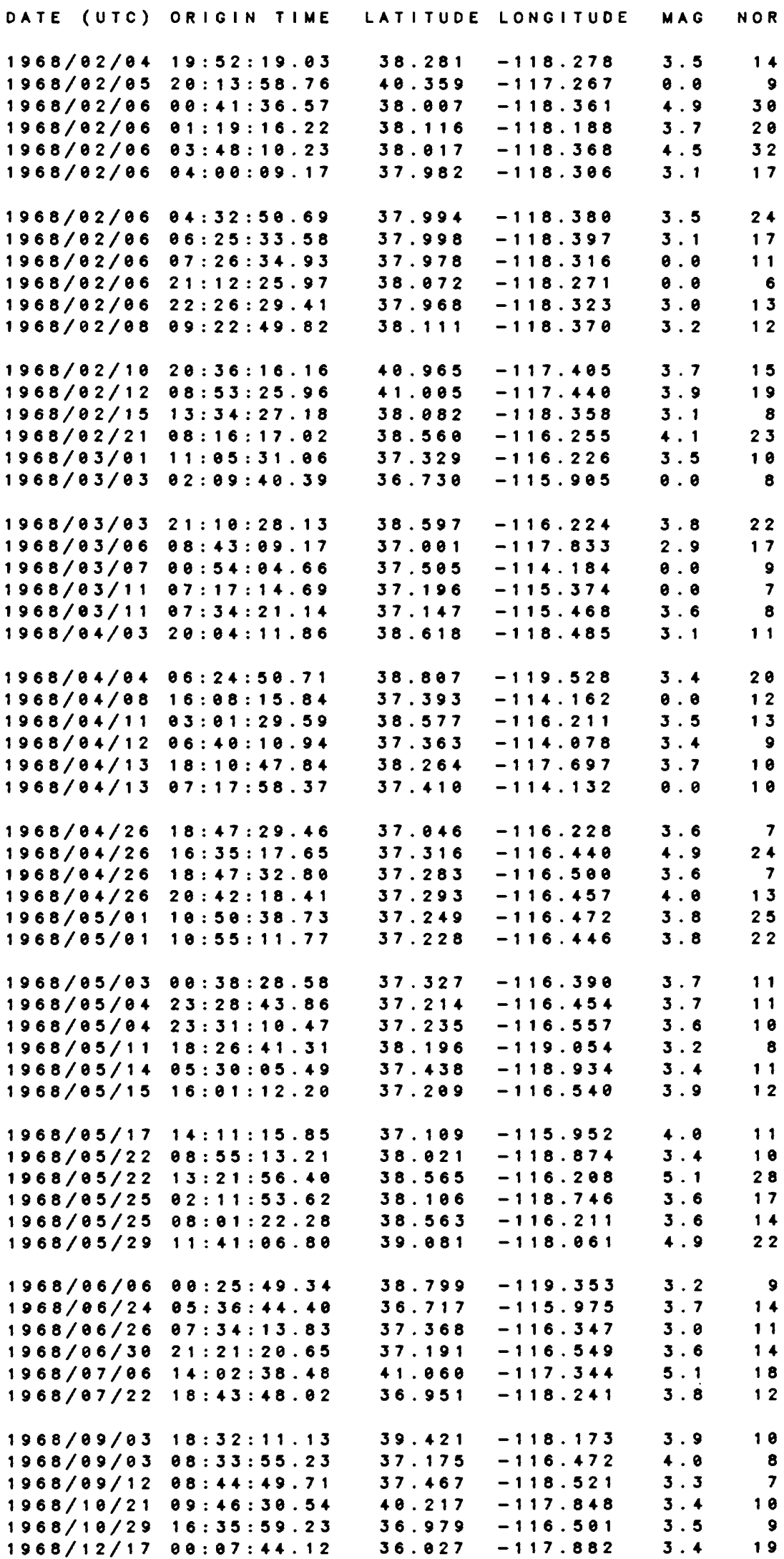




\begin{tabular}{|c|c|c|c|c|c|}
\hline$(U T C)$ & ORIGIN & LATITUDE & LONGITUDE & $M A G$ & NOR \\
\hline $1968 / 12 / 20$ & $10: 03: 41.43$ & 37.327 & -116.108 & 3.9 & 9 \\
\hline $1968 / 12 / 20$ & $20: 08: 23.67$ & 37.135 & -116.219 & 4.2 & 13 \\
\hline $1968 / 12 / 21$ & $00: 14: 26.49$ & 37.238 & -116.474 & 4.9 & 18 \\
\hline $1968 / 12 / 21$ & $15: 05: 01.90$ & 37.278 & -116.347 & 4.0 & 9 \\
\hline $1968 / 12 / 21$ & $15: 45: 22.61$ & 37.372 & -115.873 & 3.9 & 7 \\
\hline $1968 / 12 / 21$ & $19: 07: 33.88$ & 37.185 & -116.749 & $4 \cdot 1$ & 5 \\
\hline $1968 / 12 / 22$ & $09: 59: 56.70$ & 37.278 & -116.463 & 4.2 & 9 \\
\hline $1968 / 12 / 22$ & $18: 10: 53 \cdot 38$ & 37.155 & -116.511 & $4 \cdot 2$ & 18 \\
\hline $1968 / 12 / 23$ & $14: 12: 20.96$ & 38.350 & -119.289 & 3.0 & $\vartheta$ \\
\hline $1968 / 12 / 23$ & $05: 44: 04.96$ & 37.373 & -116.104 & 3.9 & 7 \\
\hline $1968 / 12 / 23$ & $05: 56: 04.38$ & 37.146 & -116.626 & 3.8 & 7 \\
\hline $1068 / 12 / 23$ & $09: 25: 30.94$ & 37.279 & -116.634 & 3.9 & 8 \\
\hline $1968 / 12 / 27$ & $23: 29: 02.84$ & 37.551 & -116.309 & 2.9 & 7 \\
\hline $1969 / 01 / 06$ & $06: 34: 16.03$ & 37.211 & -116.504 & 4.6 & 20 \\
\hline $1969 / 01 / 07$ & $13: 40: 58.49$ & 40.195 & -119.698 & 4.0 & 12 \\
\hline $1969 / 01 / 08$ & $11: 46: 56.63$ & 37.316 & -116.147 & 3.9 & 7 \\
\hline $1969 / 01 / 08$ & $20: 44: 58.45$ & 37.151 & -116.626 & 4.0 & 8 \\
\hline $1969 / 01 / 08$ & $23: 49: 22.31$ & 37.164 & -116.595 & 4.1 & 9 \\
\hline $1969 / 01 / 09$ & $00: 13: 19.44$ & 37.168 & -116.572 & 4.1 & 6 \\
\hline $1969 / 01 / 09$ & $03: 16: 00.18$ & 37.020 & -116.828 & 4.1 & 8 \\
\hline $1969 / 01 / 09$ & $10: 14: 01.45$ & 37.154 & -116.195 & 4.2 & 9 \\
\hline $1969 / 01 / 10$ & $09: 41: 23.45$ & 37.134 & -116.482 & 4.4 & 12 \\
\hline $1969 / 01 / 10$ & $17: 01: 47.69$ & 37.100 & -116.291 & 4.4 & 9 \\
\hline $1969 / 01 / 10$ & $17: 14: 18.31$ & 37.094 & -116.528 & 4.3 & 9 \\
\hline $1969 / 01 / 29$ & $13: 32: 48.34$ & 37.354 & -116.706 & $3 \cdot 9$ & 8 \\
\hline $1969 / 02 / 04$ & $15: 00: 01.18$ & 37.023 & -115.955 & $3 \cdot 7$ & 11 \\
\hline $1969 / 03 / 18$ & $14: 40: 01.68$ & 37.114 & -116.039 & 4.4 & 10 \\
\hline $1969 / 03 / 19$ & $11: 19: 22.92$ & 38.579 & -119.583 & $3 \cdot 2$ & 10 \\
\hline $1969 / 04 / 13$ & $07: 45: 41.76$ & 36.129 & -117.973 & 3.0 & 13 \\
\hline $1969 / 04 / 24$ & $13: 04: 02.13$ & 37.101 & -116.084 & 3.8 & 9 \\
\hline $1969 / 06 / 13$ & $01: 20: 19.49$ & 37.198 & -117.766 & 3.5 & 9 \\
\hline $1969 / 06 / 17$ & $05: 06: 10.49$ & 35.014 & -116.597 & 3.9 & 18 \\
\hline $1969 / 06 / 17$ & $08: 18: 18.35$ & 35.055 & -116.646 & 3.7 & 13 \\
\hline $1969 / 06 / 19$ & $07: 05: 07.52$ & 35.999 & -119.621 & $3 \cdot 8$ & 10 \\
\hline $1969 / 06 / 26$ & $16: 00: 01.58$ & 37.101 & -116.039 & 4.4 & 11 \\
\hline $1969 / 06 / 30$ & $02: 21: 18.59$ & 34.972 & -116.641 & 4.1 & 20 \\
\hline $1969 / 07 / 17$ & $20: 31: 10.67$ & 36.194 & -118.427 & $3 \cdot 3$ & 12 \\
\hline $1969 / 07 / 24$ & $18: 43: 58 \cdot 11$ & 36.259 & -118.366 & $3 \cdot 4$ & 16 \\
\hline $1969 / 07 / 26$ & $05: 32: 39.35$ & 36.279 & -118.344 & $3 \cdot 4$ & 17 \\
\hline $1969 / 07 / 26$ & $17: 19: 08.75$ & 37.280 & -114.926 & 0. 0 & 8 \\
\hline $1969 / 08 / 15$ & $11: 05: 14.71$ & 36.249 & -118.363 & 3.4 & 17 \\
\hline $1969 / 08 / 16$ & $11: 57: 46.89$ & 35.707 & -117.648 & 4.0 & 9 \\
\hline $1969 / 08 / 25$ & $08: 03: 33.02$ & 37.619 & -118.806 & 3.7 & 17 \\
\hline $1969 / 09 / 08$ & $12: 28: 24.77$ & 39.126 & -118.103 & $3 \cdot 4$ & 9 \\
\hline $1969 / 09 / 16$ & $16: 23: 55.78$ & 37.233 & -116.495 & 4.4 & 11 \\
\hline $1969 / 09 / 16$ & $17: 31: 17 \cdot 28$ & 37.409 & -116.452 & 5.0 & 7 \\
\hline $1969 / 09 / 16$ & $18: 15: 43.01$ & 37.166 & -116.316 & 4.6 & 13 \\
\hline $1969 / 09 / 20$ & $18: 37: 58.58$ & 36.177 & -118.383 & $3 \cdot 2$ & 15 \\
\hline $1969 / 09 / 20$ & $14: 30: 01.69$ & 37.148 & -116.066 & 4.3 & 14 \\
\hline $1969 / 10 / 03$ & $13: 10: 11.85$ & 37.609 & -118.914 & 4.9 & 16 \\
\hline $1969 / 10 / 03$ & $23: 32: 27.79$ & 36.217 & -118.320 & 4.0 & 16 \\
\hline $1969 / 10 / 26$ & $11: 15: 10.73$ & 36.317 & -118.382 & 2.5 & 6 \\
\hline $1969 / 10 / 27$ & $11: 17: 16.25$ & 37.464 & -119.060 & 2.8 & 7 \\
\hline $1969 / 10 / 27$ & $20: 31: 32.54$ & 36.693 & -116.072 & 0.0 & 9 \\
\hline $1969 / 10 / 28$ & $02: 32: 11.19$ & 37.166 & -117.966 & 3.7 & 24 \\
\hline $1969 / 10 / 28$ & $14: 34: 59.11$ & 37.275 & -116.442 & $3 \cdot 1$ & 12 \\
\hline $1969 / 11 / 08$ & $06: 58: 02.36$ & 37.151 & -114.978 & $3 \cdot 3$ & 15 \\
\hline $1969 / 11 / 16$ & $19: 29: 24.09$ & 36.222 & -118.336 & $3 \cdot 1$ & 20 \\
\hline $1969 / 12 / 06$ & $00: 50: 27.53$ & 35.999 & -118.262 & $3 \cdot 3$ & 8 \\
\hline $1969 / 12 / 07$ & $13: 24: 34.33$ & 36.508 & -119.426 & $3 \cdot 2$ & 7 \\
\hline
\end{tabular}




\begin{tabular}{|c|c|c|c|c|c|}
\hline DATE (UTC) & OR I G I N & LATITUDE & LONG I TUDE & $M A G$ & NOR \\
\hline $1969 / 12 / 08$ & $02: 26: 25.53$ & 37.142 & -116.961 & 3.5 & 8 \\
\hline $1969 / 12 / 10$ & $15: 30: 01.88$ & 37.146 & -116.010 & 4.6 & 14 \\
\hline $1969 / 12 / 17$ & $22: 44: 07.66$ & 37.258 & $-118 \cdot 178$ & 3.3 & 15 \\
\hline $1969 / 12 / 19$ & $09: 03: 38.79$ & 36.267 & -118.359 & $3 \cdot 1$ & 20 \\
\hline $1970 / 01 / 01$ & $19: 49: 22.24$ & 37.460 & -118.593 & 3.8 & 10 \\
\hline $1970 / 01 / 14$ & $18: 44: 20.27$ & 37.498 & -118.283 & $3 \cdot 3$ & 19 \\
\hline $1970 / 01 / 15$ & $18: 11: 17.59$ & 37.529 & -118.319 & $3 \cdot 2$ & 16 \\
\hline $1970 / 01 / 17$ & $08: 39: 16.83$ & 39.441 & -118.081 & $3 \cdot 7$ & 16 \\
\hline $1970 / 01 / 21$ & $13: 45: 53.68$ & 39.027 & -118.194 & 0.0 & 10 \\
\hline $1970 / 01 / 21$ & $17: 13: 29.09$ & 39.044 & -118.137 & $3 \cdot 2$ & 15 \\
\hline $1970 / 01 / 25$ & $20: 21: 24.17$ & 37.539 & -118.676 & $3 \cdot 4$ & 19 \\
\hline $1970 / 02 / 05$ & $19: 37: 05.38$ & 37.142 & -116.115 & $4 \cdot 3$ & 12 \\
\hline $1970 / 02 / 14$ & $19: 49: 19.39$ & 38.171 & -118.759 & 3.0 & 7 \\
\hline $1970 / 02 / 26$ & $08: 36: 47.73$ & 37.256 & -118.128 & $3 \cdot 2$ & 11 \\
\hline $1970 / 02 / 26$ & $09: 01: 05.79$ & 37.182 & -118.179 & 0.0 & 11 \\
\hline $1970 / 02 / 27$ & $00: 13: 58.56$ & 37.022 & -116.096 & $3 \cdot 5$ & 16 \\
\hline $1970 / 03 / 12$ & $11: 45: 16.42$ & 37.173 & -118.815 & 2.5 & 6 \\
\hline $1970 / 03 / 14$ & $20: 59: 37.95$ & 37.396 & -118.107 & 3.0 & 7 \\
\hline $1970 / 03 / 18$ & $16: 38: 48.88$ & 36.291 & -118.352 & 3.4 & 15 \\
\hline $1970 / 03 / 18$ & $17: 00: 45.28$ & 36.255 & -118.363 & 3.0 & 13 \\
\hline $1970 / 03 / 20$ & $10: 18: 44.88$ & 36.868 & -118.086 & $3 \cdot 2$ & 10 \\
\hline $1970 / 03 / 23$ & $21: 55: 40.19$ & 39.688 & -118.090 & 3.8 & 16 \\
\hline $1970 / 03 / 23$ & $19: 52: 11.90$ & 37.711 & -115.987 & 4.3 & 27 \\
\hline $1970 / 03 / 24$ & $03: 52: 33.32$ & 36.256 & -118.358 & 3.7 & 21 \\
\hline $1970 / 03 / 24$ & $05: 14: 43.71$ & 39.497 & -118.158 & 4.3 & 23 \\
\hline $1970 / 03 / 26$ & $16: 18: 32.54$ & 38.611 & -119.285 & $3 \cdot 4$ & 15 \\
\hline $1970 / 03 / 27$ & $05: 51: 09.67$ & 37.191 & -116.538 & 4.0 & 10 \\
\hline $1970 / 03 / 27$ & $16: 42: 18.80$ & 37.503 & -118.456 & $4 \cdot 1$ & 7 \\
\hline $1970 / 03 / 27$ & $18: 08: 25.70$ & 37.235 & -116.609 & 4.2 & 18 \\
\hline $1970 / 03 / 27$ & $18: 18: 32.63$ & 37.243 & -116.593 & 4.9 & 12 \\
\hline $1970 / 03 / 28$ & $09: 38: 44.38$ & 38.863 & -116.307 & 4.4 & 41 \\
\hline $1970 / 03 / 28$ & $10: 53: 39.71$ & 38.867 & -116.397 & 0.0 & 8 \\
\hline $1070 / 04 / 12$ & $06: 41: 24.06$ & 37.233 & -116.629 & $3 \cdot 2$ & 10 \\
\hline $1970 / 04 / 18$ & $13: 16: 54.20$ & 36.618 & -120.100 & 3.0 & 8 \\
\hline $1970 / 04 / 20$ & $21: 16: 49.32$ & 37.314 & -116.568 & $\theta .0$ & 11 \\
\hline $1970 / 05 / 01$ & $14: 48: 59.50$ & 37.027 & -116.010 & 3.8 & 9 \\
\hline $1970 / 05 / 05$ & $02: 18: 30.40$ & 36.383 & -118.551 & 2.8 & 7 \\
\hline $1970 / 05 / 14$ & $18: 50: 21.09$ & 41.007 & -117.351 & 0.0 & 12 \\
\hline $1970 / 05 / 15$ & $13: 57: 23.43$ & 37.163 & -116.036 & 3.5 & 16 \\
\hline $1970 / 05 / 18$ & $20: 10: 42.37$ & 36.378 & -117.920 & 3.7 & 25 \\
\hline $1970 / 05 / 28$ & $12: 00: 01.81$ & 37.200 & -116.049 & 4.2 & 9 \\
\hline $1970 / 07 / 07$ & $10: 48: 34.85$ & 36.036 & -117.677 & $3 \cdot 1$ & 13 \\
\hline $1970 / 07 / 08$ & $09: 25: 29.48$ & 35.337 & -117.784 & 4.5 & 20 \\
\hline $1970 / 07 / 17$ & $12: 47: 42.34$ & 37.458 & -117.901 & 3.0 & 16 \\
\hline $1970 / 07 / 26$ & $21: 57: 59.95$ & 39.283 & -114.947 & 3.7 & 6 \\
\hline $1970 / 07 / 27$ & $08: 43: 58.99$ & 39.032 & -118.162 & 0.0 & 12 \\
\hline $1970 / 07 / 28$ & $17: 02: 10.23$ & 36.947 & -114.965 & 0.0 & 9 \\
\hline $1970 / 07 / 20$ & $01: 23: 16.87$ & 35.969 & -117.658 & 3.0 & 14 \\
\hline $1970 / 07 / 29$ & $18: 10: 58.86$ & 37.301 & -116.705 & 0.0 & 8 \\
\hline $1970 / 07 / 30$ & $09: 57: 13.41$ & 37.572 & -118.847 & $3 \cdot 2$ & 19 \\
\hline $1970 / 07 / 30$ & $20: 16: 37.34$ & 37.268 & -116.513 & $4 \cdot 1$ & 19 \\
\hline $1970 / 08 / 08$ & $01: 01: 49.74$ & 37.409 & -118.444 & $3 \cdot 1$ & 6 \\
\hline $1970 / 08 / 10$ & $10: 48: 57.54$ & 37.196 & -115.864 & $4 \cdot 1$ & 23 \\
\hline $1970 / 08 / 12$ & $11: 45: 02.55$ & 36.030 & -118.014 & 2.7 & 14 \\
\hline $1976 / 09 / 19$ & $16: 27: 28.11$ & 37.012 & -117.855 & $3 \cdot 1$ & 16 \\
\hline $1970 / 09 / 21$ & $14: 59: 41.56$ & 37.269 & -116.586 & $\theta .0$ & 12 \\
\hline $1970 / 10 / 06$ & $13: 30: 03.04$ & 37.960 & -118.988 & $\theta \cdot \theta$ & 20 \\
\hline $1970 / 10 / 13$ & $15: 05: 01.48$ & 37.110 & -116.075 & 3.8 & 15 \\
\hline $1970 / 10 / 18$ & $11: 03: 45.72$ & 37.278 & -117.350 & 2.9 & 14 \\
\hline $1970 / 11 / 03$ & $16: 41: 17.61$ & 37.262 & -115.038 & $\theta .0$ & 13 \\
\hline
\end{tabular}




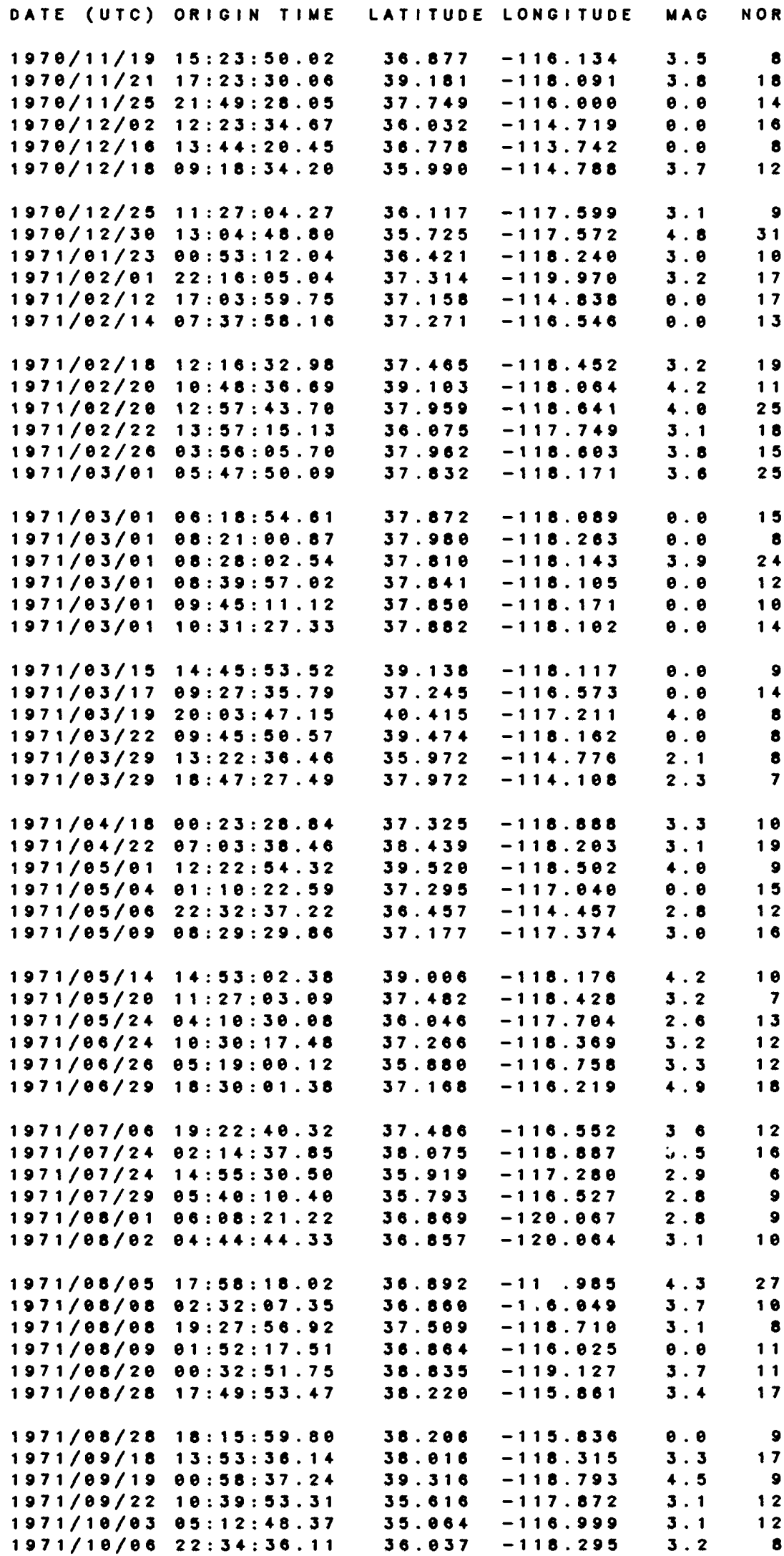




\begin{tabular}{|c|c|c|c|c|c|}
\hline DATE (UTC) & $O R|G| N$ & LATITUDE & LONGITUDE & $M A G$ & NOR \\
\hline $1971 / 10 / 07$ & $09: 27: 57.95$ & 36.870 & -116.015 & 3.9 & 13 \\
\hline $1971 / 10 / 14$ & $14: 30: 01.02$ & 37.146 & -116.031 & 4.4 & 12 \\
\hline $1971 / 11 / 07$ & $15: 44: 28.74$ & 37.467 & -118.802 & 3.2 & 10 \\
\hline $1971 / 11 / 15$ & $04: 04: 17.16$ & 39.030 & -118.380 & 4.1 & 13 \\
\hline $1971 / 11 / 20$ & $82: 11: 26.62$ & 39.036 & -118.187 & B. 8 & 10 \\
\hline $1971 / 11 / 21$ & $22: 09: 10.22$ & 39.018 & -118.368 & 0.0 & 10 \\
\hline $1971 / 11 / 22$ & $10: 39: 27.74$ & 39.021 & -118.319 & 4.0 & 12 \\
\hline $1971 / 11 / 22$ & $10: 50: 30.83$ & 37.306 & -115.268 & 0.0 & 11 \\
\hline $1971 / 11 / 24$ & $20: 15: 03.55$ & 36.725 & -116.121 & 3.8 & 9 \\
\hline $1971 / 11 / 25$ & $18: 27: 26.38$ & 37.725 & -115.076 & 0. 0 & 17 \\
\hline $1971 / 11 / 30$ & $15: 45: 01.41$ & 37.136 & -116.098 & 4.7 & 16 \\
\hline $1971 / 12 / 07$ & $19: 52: 06.11$ & 38.218 & -118.400 & $3 \cdot 9$ & 16 \\
\hline $1971 / 12 / 08$ & $17: 18: 53.27$ & 37.645 & -115.109 & 4.8 & 21 \\
\hline $1971 / 12 / 14$ & $21: 09: 59.80$ & 37.083 & -116.083 & 4.7 & 27 \\
\hline $1971 / 12 / 26$ & $17: 32: 05.06$ & 36.142 & -118.232 & 3.0 & 10 \\
\hline $1971 / 12 / 26$ & $06: 03: 56.28$ & 37.409 & -114.541 & $4 \cdot 1$ & 24 \\
\hline $1972 / 01 / 16$ & $11: 58: 56.67$ & 37.607 & -118.999 & $3 \cdot 5$ & 8 \\
\hline $1972 / 01 / 22$ & $02: 57: 20.80$ & 37.512 & -118.395 & 4.6 & 15 \\
\hline $1972 / 01 / 24$ & $13: 30: 54.49$ & 36.664 & -115.545 & $3 \cdot 2$ & 9 \\
\hline $1972 / 01 / 26$ & $02: 57: 18.50$ & 37.553 & -118.499 & 0. 0 & 9 \\
\hline $1972 / 02 / 08$ & $00: 30: 13.17$ & 37.312 & -120.062 & $2 \cdot 9$ & 7 \\
\hline $1972 / 02 / 17$ & $19: 02: 01.61$ & 37.144 & -116.065 & 4.6 & 16 \\
\hline $1972 / 02 / 17$ & $07: 55: 32.19$ & 37.167 & -117.576 & $3 \cdot 2$ & 13 \\
\hline $1972 / 02 / 17$ & $11: 09: 59.39$ & 37.521 & -118.433 & 4.0 & 13 \\
\hline $1972 / 02 / 23$ & $15: 49: 05.83$ & 40.202 & -117.459 & 0.0 & 17 \\
\hline $1972 / 03 / 21$ & $01: 21: 11: 45$ & 36.212 & -117.672 & $3 \cdot 4$ & 10 \\
\hline $1972 / 03 / 25$ & $13: 41: 36.86$ & 37.306 & -116.403 & 0.0 & 15 \\
\hline $1972 / 03 / 31$ & $21: 14: 05.69$ & 36.796 & -120.010 & $3 \cdot 7$ & 12 \\
\hline $1972 / 04 / 02$ & $06: 44: 57.11$ & 35.472 & -117.533 & $3 \cdot 0$ & 6 \\
\hline $1972 / 04 / 19$ & $16: 32: 01.34$ & 37.065 & -116.083 & 4.6 & 19 \\
\hline $1972 / 04 / 30$ & $02: 46: 20.92$ & 37.519 & -118.416 & 3.8 & 14 \\
\hline $1972 / 05 / 02$ & $19: 15: 01.61$ & 37.200 & -116.254 & 5.0 & 15 \\
\hline $1972 / 05 / 11$ & $04: 50: 46.41$ & 35.074 & -116.600 & $2 \cdot 9$ & 9 \\
\hline $1972 / 05 / 13$ & $02: 54: 11.63$ & 37.409 & -118.451 & $3 \cdot 2$ & 20 \\
\hline $1972 / 05 / 17$ & $14: 10: 01.21$ & 37.084 & -116.070 & 4.4 & 20 \\
\hline $1972 / 05 / 19$ & $17: 80: 00.75$ & 37.042 & -115.998 & 4.9 & 25 \\
\hline $1972 / 06 / 02$ & $11: 46: 14.75$ & 39.066 & -118.063 & $4 \cdot 1$ & 14 \\
\hline $1972 / 06 / 05$ & $23: 59: 54.78$ & 37.218 & -117.875 & 3.0 & 11 \\
\hline $1972 / 06 / 89$ & $08: 14: 51.73$ & 37.327 & -118.329 & $2 \cdot 5$ & 11 \\
\hline $1972 / 06 / 13$ & $08: 47: 01.62$ & 35.569 & -117.516 & $3 \cdot 1$ & 15 \\
\hline $1972 / 86 / 18$ & $02: 49: 00.64$ & 37.782 & -118.761 & $2 \cdot 5$ & 7 \\
\hline $1972 / 86 / 18$ & $02: 51: 22.23$ & 37.666 & -118.760 & $3 \cdot 6$ & 8 \\
\hline $1972 / 06 / 18$ & $03: 12: 04.63$ & 37.664 & -118.762 & 3.6 & 6 \\
\hline $1972 / 06 / 18$ & $03: 43: 12.49$ & 37.679 & -118.826 & 3.6 & 12 \\
\hline $1972 / 06 / 26$ & $06: 13: 21.26$ & 35.856 & -117.643 & $2 \cdot 9$ & 11 \\
\hline $1972 / 06 / 26$ & $09: 21: 14.34$ & 35.847 & -117.646 & 3.0 & 13 \\
\hline $1972 / 06 / 28$ & $05: 29: 10.44$ & 35.786 & -117.608 & $3 \cdot 2$ & 15 \\
\hline $1972 / 06 / 28$ & $16: 30: 82.06$ & 37.104 & -116.068 & 0.0 & 8 \\
\hline $1972 / 07 / 01$ & $06: 45: 15.94$ & 37.384 & -118.517 & 3.5 & 15 \\
\hline $1972 / 07 / 04$ & $08: 20: 03.59$ & 35.789 & -117.584 & $4 \cdot 4$ & 31 \\
\hline $1972 / 07 / 04$ & $08: 37: 15.87$ & 35.798 & -117.573 & $3 \cdot 4$ & 21 \\
\hline $1972 / 07 / 08$ & $07: 30: 12.53$ & 36.814 & -115.344 & 0.0 & 12 \\
\hline $1972 / 07 / 25$ & $13: 30: 01.76$ & 36.953 & -116.009 & $4 \cdot 0$ & 12 \\
\hline $1972 / 07 / 29$ & $04: 44: 59.83$ & 35.792 & -117.590 & 3.0 & 15 \\
\hline $1972 / 07 / 30$ & $06: 40: 06.80$ & 37.477 & -114.998 & 0. 0 & 8 \\
\hline $1972 / 07 / 30$ & $06: 41: 45.83$ & 37.424 & -114.985 & B. 8 & 8 \\
\hline $1972 / 07 / 30$ & $09: 04: 37.86$ & 37.478 & -114.998 & 0.0 & 8 \\
\hline $1972 / 07 / 30$ & $14: 09: 54.82$ & 35.814 & -117.591 & 3.0 & 15 \\
\hline $1972 / 07 / 30$ & $19: 02: 14.72$ & 35.775 & -117.639 & 3.4 & 18 \\
\hline $1972 / 07 / 30$ & $21: 17: 05.39$ & 35.780 & -117.649 & $3 \cdot 3$ & 11 \\
\hline
\end{tabular}




\begin{tabular}{|c|c|c|c|c|c|}
\hline DATE (UTC) & $O R I G I N$ & LATITUDE & LONGITUDE & MAG & NOR \\
\hline $1972 / 08 / 01$ & $03: 14: 33.01$ & 36.150 & -117.656 & 2.7 & 11 \\
\hline $1972 / 08 / 30$ & $10: 22: 15.30$ & 36.855 & -120.040 & 2.8 & 10 \\
\hline $1972 / 09 / 06$ & $03: 53: 53.08$ & 37.119 & -117.596 & 2.7 & 9 \\
\hline $1972 / 00 / 18$ & $21: 50: 52.31$ & 37.549 & -118.314 & 4.0 & 10 \\
\hline $1072 / 00 / 22$ & $08: 48: 21.30$ & 37.985 & -118.123 & 3.3 & 16 \\
\hline $1972 / 00 / 23$ & $06: 14: 48.12$ & 36.776 & -115.848 & 3.0 & 15 \\
\hline $1972 / 09 / 26$ & $12: 32: 47.85$ & 36.027 & -118.255 & 2.0 & 11 \\
\hline $1972 / 09 / 20$ & $12: 29: 52.91$ & 37.426 & -115.290 & e. 0 & 12 \\
\hline $1972 / 10 / 24$ & $13: 21: 47.30$ & 37.217 & -114.832 & 0.0 & 10 \\
\hline $1972 / 10 / 27$ & $19: 49: 27.55$ & 35.049 & -116.387 & $3 \cdot 1$ & 10 \\
\hline $1972 / 10 / 28$ & $10: 01: 25.22$ & 37.230 & -114.838 & $3 \cdot 4$ & 12 \\
\hline $1972 / 10 / 28$ & $02: 12: 47.12$ & 38.998 & -118.962 & 0.0 & 12 \\
\hline $1972 / 10 / 29$ & $11: 35: 07.42$ & 37.233 & -114.851 & $3 \cdot 2$ & 10 \\
\hline $1072 / 10 / 20$ & $20: 27: 04.42$ & 37.240 & -114.828 & $3 \cdot 1$ & 10 \\
\hline $1072 / 10 / 30$ & $02: 07: 20.48$ & 37.243 & -114.836 & 0.0 & 8 \\
\hline $1972 / 10 / 30$ & $07: 08: 20.72$ & 37.255 & -114.817 & 0.0 & 10 \\
\hline $1072 / 10 / 30$ & $08: 13: 09.05$ & 37.266 & -114.837 & e. 0 & 8 \\
\hline $1972 / 10 / 30$ & $14: 03: 06.36$ & 37.237 & -114.843 & 0.0 & 9 \\
\hline $1972 / 11 / 08$ & $10: 15: 10.05$ & 36.912 & -117.911 & $3 \cdot 1$ & 13 \\
\hline $1972 / 11 / 13$ & $01: 18: 13.87$ & 36.142 & -117.546 & 2.9 & 13 \\
\hline $1972 / 11 / 17$ & $07: 46: 58.40$ & 37.782 & -115.126 & 0.0 & 11 \\
\hline $1972 / 11 / 17$ & $00: 20: 08.71$ & 37.781 & -115.131 & 0. 0 & 10 \\
\hline $1972 / 11 / 17$ & $00: 50: 04.18$ & 37.781 & -115.130 & 4.6 & 16 \\
\hline $1972 / 11 / 17$ & $23: 18: 42.91$ & 37.760 & $-115 \cdot 144$ & e. 0 & 12 \\
\hline $1972 / 11 / 17$ & $18: 27: 55.31$ & 35.835 & -116.250 & 2.6 & 10 \\
\hline $1972 / 11 / 18$ & $02: 10: 29.98$ & 36.046 & -117.485 & $3 \cdot 5$ & 14 \\
\hline $1972 / 11 / 25$ & $19: 31: 30.20$ & 36.673 & -118.003 & 2.8 & 13 \\
\hline $1972 / 11 / 29$ & $05: 45: 37.09$ & 37.759 & -114.520 & 2.0 & 13 \\
\hline $1972 / 11 / 29$ & $05: 53: 20.27$ & 37.798 & -114.510 & 3.0 & 13 \\
\hline $1972 / 12 / 02$ & $13: 19: 50.41$ & 39.617 & -110.431 & 4.2 & 14 \\
\hline $1972 / 12 / 09$ & $02: 44: 46.26$ & 38.670 & -115.664 & 4.6 & 24 \\
\hline $1972 / 12 / 21$ & $02: 37: 55.12$ & 35.930 & -117.700 & $3 \cdot 9$ & 25 \\
\hline $1972 / 12 / 21$ & $02: 50: 07.01$ & 35.940 & -117.787 & $\mathbf{3} \cdot \mathbf{3}$ & 14 \\
\hline $1972 / 12 / 21$ & $02: 56: 36.32$ & 35.954 & -117.776 & $3 \cdot 3$ & 15 \\
\hline $1972 / 12 / 21$ & $05: 15: 53.24$ & 35.928 & -117.703 & 3.6 & 24 \\
\hline $1972 / 12 / 21$ & $10: 31: 27.57$ & 35.920 & -117.696 & $3 \cdot 7$ & 23 \\
\hline $1972 / 12 / 22$ & $02: 37: 44.73$ & 35.959 & -117.771 & 2.6 & 7 \\
\hline $1072 / 12 / 27$ & $15: 27: 48.75$ & 37.113 & -116.930 & e. 0 & 11 \\
\hline $1973 / 01 / 11$ & $10: 53: 48.83$ & 35.751 & -118.013 & 0 & 11 \\
\hline $1073 / 01 / 12$ & $01: 52: 28.85$ & 40.194 & -116.750 & 0.0 & 11 \\
\hline $1973 / 01 / 13$ & $10: 55: 13.54$ & 37.316 & -115.492 & e. 0 & 9 \\
\hline $1073 / 01 / 13$ & $18: 26: 10.83$ & 37.090 & -115.531 & 0.0 & 10 \\
\hline $1073 / 01 / 15$ & $19: 32: 39.80$ & 36.355 & -114.919 & e. 0 & 6 \\
\hline $1073 / 01 / 25$ & $06: 30: 01.07$ & 40.617 & -119.733 & $3 \cdot 7$ & 9 \\
\hline $1973 / 02 / 03$ & $05: 15: 27.68$ & 37.385 & -115.686 & e. 0 & 20 \\
\hline $1073 / 02 / 09$ & $23: 09: 52.31$ & 36.826 & -115.013 & 0.0 & 17 \\
\hline $1973 / 02 / 00$ & $23: 10: 34.80$ & 36.839 & -115.920 & 4.2 & 20 \\
\hline $1973 / 02 / 11$ & $04: 02: 40.46$ & 36.759 & -116.022 & 0.0 & 14 \\
\hline $1973 / 02 / 11$ & $06: 38: 55.52$ & 36.803 & -115.000 & 0.0 & 13 \\
\hline $1973 / 02 / 13$ & $20: 21: 50.66$ & 36.801 & -115.894 & 0.0 & 14 \\
\hline $1973 / 02 / 15$ & $00: 15: 46.44$ & 36.809 & -115.886 & 0. 0 & 11 \\
\hline $1973 / 02 / 15$ & $23: 06: 00.07$ & 36.812 & -115.930 & e. 8 & 23 \\
\hline $1973 / 02 / 15$ & $23: 14: 57.98$ & 36.812 & -115.945 & 0.0 & 21 \\
\hline $1973 / 02 / 16$ & $06: 32: 54.36$ & 36.815 & -115.927 & 0.0 & 16 \\
\hline $1973 / 02 / 18$ & $18: 04: 45.21$ & 36.817 & -115.934 & e. 0 & 28 \\
\hline $1973 / 02 / 19$ & $11: 15: 22: 76$ & 36.805 & -115.037 & 4.0 & 28 \\
\hline $1073 / 02 / 10$ & $11: 30: 01.04$ & 36.824 & -115.906 & 0.0 & 18 \\
\hline $1073 / 02 / 10$ & $12: 22: 32 \cdot 38$ & 36.818 & -115.910 & 0.0 & 18 \\
\hline $1073 / 02 / 10$ & $12: 55: 57.46$ & 36.826 & -115.924 & 0. 0 & 14 \\
\hline $1973 / 02 / 10$ & $13: 43: 20.07$ & 36.810 & -115.923 & 0.0 & 27 \\
\hline
\end{tabular}




\begin{tabular}{|c|c|c|c|c|c|}
\hline$(\mathrm{UTC})$ & $O R|G| N$ & LATITUDE & LONGITUDE & $M A G$ & NOR \\
\hline $1973 / 02 / 19$ & $14: 41: 08.66$ & 36.831 & -115.913 & 0.0 & 12 \\
\hline $1973 / 02 / 19$ & $17: 32: 33.97$ & 36.804 & -115.901 & 0.0 & 10 \\
\hline $1973 / 02 / 19$ & $18: 53: 03.34$ & 36.801 & -115.860 & 0.0 & 8 \\
\hline $1973 / 02 / 19$ & $19: 35: 46.63$ & 36.804 & -115.890 & 0.0 & 12 \\
\hline $1973 / 02 / 20$ & $15: 43: 08.92$ & 36.834 & -115.892 & $\theta .0$ & 16 \\
\hline $1973 / 02 / 21$ & $00: 28: 10.09$ & 36.817 & -115.900 & 0.0 & 15 \\
\hline $1973 / 02 / 21$ & $10: 01: 07.74$ & 36.807 & -115.888 & 0.0 & 10 \\
\hline $1973 / 02 / 22$ & $01: 23: 24.75$ & 36.804 & -115.902 & 0.0 & 8 \\
\hline $1973 / 02 / 23$ & $04: 13: 19.60$ & 36.804 & -115.886 & 0.0 & 7 \\
\hline $1973 / 02 / 25$ & $07: 34: 15: 57$ & 37.380 & -115.673 & 0.0 & 9 \\
\hline $1973 / 02 / 25$ & $04: 09: 25.90$ & 36.806 & -115.849 & 0.0 & 9 \\
\hline $1973 / 02 / 25$ & $04: 11: 31.82$ & 36.806 & -115.896 & 0.0 & 10 \\
\hline $1973 / 02 / 25$ & $13: 00: 41.57$ & 36.762 & -115.892 & 0.0 & 7 \\
\hline $1973 / 02 / 25$ & $15: 38: 37.84$ & 36.752 & -115.945 & 0.0 & 8 \\
\hline $1973 / 02 / 26$ & $03: 55: 10.92$ & 36.659 & -115.259 & 3.6 & 10 \\
\hline $1073 / 02 / 27$ & $02: 43: 10.12$ & 36.808 & -115.907 & 0.0 & 11 \\
\hline $1973 / 02 / 27$ & $03: 43: 29.27$ & 36.820 & -115.930 & 0.0 & 14 \\
\hline $1973 / 02 / 27$ & $08: 38: 50 \cdot 17$ & 36.809 & -115.901 & 0.0 & 11 \\
\hline $1973 / 02 / 27$ & $09: 55: 22.28$ & 36.799 & -115.796 & 0.0 & 11 \\
\hline $1973 / 02 / 27$ & $11: 50: 35.76$ & 36.759 & -115.896 & 0.0 & 10 \\
\hline $1973 / 02 / 27$ & $13: 03: 01.54$ & 36.810 & -115.899 & 0.0 & 11 \\
\hline $1973 / 02 / 28$ & $03: 34: 18 \cdot 38$ & 38.807 & -115.908 & 0.0 & 11 \\
\hline $1973 / 02 / 28$ & $11: 01: 16.19$ & 38.805 & -115.902 & 0.0 & 9 \\
\hline $1973 / 03 / 05$ & $08: 34: 15.80$ & 36.965 & -115.086 & 0.0 & 13 \\
\hline $1973 / 03 / 12$ & $15: 08: 34.93$ & 35.917 & -117.221 & $3 \cdot 3$ & 14 \\
\hline $1973 / 03 / 13$ & $11: 17: 06.32$ & 36.816 & -115.908 & 0.0 & 14 \\
\hline $1973 / 03 / 13$ & $22: 31: 34.52$ & 36.819 & -115.937 & 0.0 & 17 \\
\hline $1973 / 03 / 27$ & $01: 00: 19.50$ & 37.453 & -115.686 & 0.0 & 11 \\
\hline $1973 / 03 / 28$ & $11: 51: 42 \cdot 14$ & 36.800 & -115.907 & 0.0 & 8 \\
\hline $1973 / 03 / 30$ & $14: 16: 32.78$ & 38.416 & -117.955 & 0.0 & 10 \\
\hline $1973 / 04 / 13$ & $08: 45: 32.02$ & 35.684 & -116.569 & 3.0 & 15 \\
\hline $1973 / 04 / 13$ & $04: 36: 59.95$ & 36.007 & -116.153 & 0.0 & 8 \\
\hline $1973 / 04 / 20$ & $00: 49: 33.97$ & 36.534 & -117.985 & $3 \cdot 3$ & 14 \\
\hline $1973 / 04 / 20$ & $03: 44: 44.60$ & 37.112 & -118.189 & $3 \cdot 4$ & 10 \\
\hline $1973 / 04 / 21$ & $05: 50: 40.89$ & 37.114 & -118.268 & $3 \cdot 2$ & 8 \\
\hline $1973 / 04 / 23$ & $06: 58: 35.96$ & 37.408 & -115.245 & 0.0 & 8 \\
\hline $1973 / 04 / 26$ & $15: 15: 02.00$ & 36.985 & -116.008 & $4 \cdot 1$ & 8 \\
\hline $1973 / 04 / 26$ & $17: 15: 01.08$ & 37.081 & -116.074 & $5 \cdot 6$ & 20 \\
\hline $1973 / 04 / 28$ & $22: 13: 17.21$ & 37.498 & -118.429 & $2 \cdot 9$ & 9 \\
\hline $1973 / 05 / 10$ & $05: 32: 23.86$ & 35.931 & -117.256 & $3 \cdot 1$ & 12 \\
\hline $1973 / 05 / 12$ & $23: 39: 50.41$ & 37.462 & -114.218 & 0.0 & 7 \\
\hline $1973 / 85 / 14$ & $01: 01: 09.15$ & 37.294 & -114.220 & 0.0 & 10 \\
\hline $1973 / 05 / 15$ & $17: 18: 50.29$ & 35.104 & -117.520 & $3 \cdot 3$ & 9 \\
\hline $1973 / 05 / 24$ & $13: 30: 01.58$ & 37.145 & -116.088 & 4.8 & 13 \\
\hline $1973 / 05 / 27$ & $02: 39: 27.07$ & 37.335 & -115.073 & 0.0 & 12 \\
\hline $1973 / 05 / 27$ & $21: 59: 24.15$ & 39.243 & -114.978 & 0.0 & 9 \\
\hline $1973 / 06 / 05$ & $09: 11: 03.10$ & 37.390 & -118.517 & $3 \cdot 3$ & 13 \\
\hline $1973 / 06 / 10$ & $22: 22: 08.38$ & 37.221 & -116.373 & 3.8 & 14 \\
\hline $1973 / 06 / 10$ & $06: 38: 17.92$ & 36.095 & -117.904 & 2.9 & 8 \\
\hline $1973 / 06 / 11$ & $07: 56: 22.22$ & 37.231 & -116.312 & $3 \cdot 2$ & 9 \\
\hline $1973 / 06 / 12$ & $06: 48: 52.36$ & 37.223 & -116.332 & $3 \cdot 4$ & 8 \\
\hline $1973 / 06 / 12$ & $08: 15: 50.67$ & 37.203 & -116.298 & 4.8 & 19 \\
\hline $1973 / 06 / 16$ & $18: 53: 30.13$ & 39.258 & -115.097 & 0.0 & 6 \\
\hline $1973 / 06 / 16$ & $23: 54: 44.83$ & 40.007 & -119.225 & 3.9 & 10 \\
\hline $1973 / 06 / 17$ & $00: 00: 46.30$ & 40.166 & -119.058 & $3 \cdot 6$ & 7 \\
\hline $1973 / 06 / 17$ & $02: 41: 14.28$ & 40.038 & -119.173 & 3.6 & 11 \\
\hline $1973 / 06 / 18$ & $20: 34: 18.91$ & 37.454 & -116.604 & 0.0 & 7 \\
\hline $1973 / 06 / 18$ & $06: 49: 38.79$ & 39.895 & -118.914 & $3 \cdot 6$ & 9 \\
\hline $1973 / 06 / 21$ & $14: 45: 00.61$ & 37.071 & -116.005 & $5 \cdot 3$ & 14 \\
\hline $1973 / 06 / 21$ & $22: 02: 13.48$ & 39.181 & -115.146 & 0.0 & 6 \\
\hline
\end{tabular}




\begin{tabular}{|c|c|c|c|c|c|}
\hline DATE (UTC) & OR I GIN & LATITUDE & LONGITUDE & $M A G$ & NOR \\
\hline $1973 / 06 / 22$ & $17: 20: 51: 35$ & 37.109 & -116.938 & 0.0 & \\
\hline $1973 / 06 / 23$ & $21: 57: 57.55$ & 39.282 & -114.958 & 0.0 & 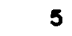 \\
\hline $1973 / 06 / 24$ & $11: 37: 37.73$ & 37.470 & -116.607 & 4.2 & \\
\hline $1973 / 06 / 27$ & $17: 07: 26.65$ & $37 \cdot 108$ & -116.934 & 0.0 & 7 \\
\hline $1973 / 07 / 04$ & $12: 25: 41.03$ & 37.386 & -118.538 & 3.2 & 16 \\
\hline $1973 / 07 / 13$ & $00: 02: 54.39$ & 37.210 & -116.333 & 0.0 & 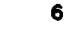 \\
\hline $1973 / 07 / 30$ & $09: 18: 43.20$ & 37.624 & -115.139 & 3.5 & 12 \\
\hline $1973 / 08 / 25$ & $23: 09: 44.49$ & 37.340 & -118.286 & $3 \cdot 3$ & 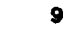 \\
\hline $1973 / 08 / 27$ & $06: 28: 58.29$ & 39.006 & -118.176 & $3 \cdot 2$ & 6 \\
\hline $1973 / 09 / 11$ & $02: 39: 48.01$ & 37.614 & -118.981 & $3 \cdot 9$ & 14 \\
\hline $1973 / 09 / 14$ & $22: 19: 08.17$ & 37.749 & -115.117 & 0.0 & 11 \\
\hline $1973 / 09 / 15$ & $01: 03: 14.69$ & 36.600 & -119.385 & $4 \cdot 2$ & 15 \\
\hline $1973 / 09 / 18$ & $10: 08: 06.00$ & 37.217 & -118.941 & 3.7 & 13 \\
\hline $1973 / 09 / 19$ & $16: 48: 53.02$ & 35.606 & -117.483 & $3 \cdot 1$ & 8 \\
\hline $1973 / 09 / 20$ & $03: 26: 19.08$ & 39.025 & -115.902 & 0.0 & 10 \\
\hline $1973 / 09 / 25$ & $02: 52: 13.84$ & 39.241 & -116.383 & 3.6 & 18 \\
\hline $1973 / 10 / 06$ & $07: 36: 10.53$ & 36.062 & -117.408 & $2 \cdot 7$ & 9 \\
\hline $1973 / 10 / 07$ & $16: 39: 31.35$ & 37.609 & -118.932 & $3 \cdot 5$ & $s$ \\
\hline $1973 / 10 / 07$ & $17: 30: 52.06$ & 37.584 & -118.936 & 3.9 & 10 \\
\hline $1973 / 10 / 12$ & $17: 20: 29.03$ & 37.521 & -118.545 & $3 \cdot 4$ & 9 \\
\hline $1973 / 10 / 17$ & $15: 34: 28.54$ & 37.577 & -118.957 & 3.9 & 10 \\
\hline $1973 / 10 / 20$ & $08: 09: 12.87$ & 35.001 & -117.050 & $3 \cdot 3$ & 6 \\
\hline $1973 / 11 / 28$ & $15: 30: 01.50$ & 36.944 & -116.052 & 4.4 & 10 \\
\hline $1973 / 12 / 14$ & $05: 27: 34.82$ & 37.952 & -118.297 & $3 \cdot 4$ & 10 \\
\hline $1974 / 01 / 02$ & $13: 49: 55.84$ & 35.584 & -117.238 & 4.2 & 19 \\
\hline $1974 / 01 / 30$ & $07: 12: 33: 11$ & 37.436 & -118.538 & $3 \cdot 1$ & 8 \\
\hline $1974 / 03 / 18$ & $12: 14: 27.35$ & 40.046 & -116.811 & 4.3 & 10 \\
\hline $1974 / 03 / 18$ & $12: 54: 58.07$ & 40.072 & -116.788 & $4 \cdot 1$ & 11 \\
\hline $1974 / 04 / 23$ & $15: 13: 00.11$ & 37.006 & -116.221 & 3.4 & 7 \\
\hline $1974 / 05 / 13$ & $08: 46: 19 \cdot 44$ & 36.851 & -117.820 & $2 \cdot 3$ & 6 \\
\hline $1974 / 05 / 22$ & $14: 15: 01.29$ & 37.072 & -116.091 & $4 \cdot 4$ & 12 \\
\hline $1974 / 05 / 23$ & $13: 38: 31: 13$ & 37.104 & -116.082 & 4.8 & 18 \\
\hline $1974 / 05 / 29$ & $18: 10: 40.76$ & 36.835 & -115.897 & 4.0 & 14 \\
\hline $1974 / 05 / 29$ & $19: 23: 31: 36$ & 36.972 & -115.836 & 4.0 & 17 \\
\hline $1974 / 06 / 09$ & $22: 27: 32.88$ & 35.513 & -117.458 & 4.0 & 14 \\
\hline $1974 / 06 / 10$ & $06: 44: 09.18$ & 35.509 & -117.441 & $4 \cdot 1$ & 21 \\
\hline $1974 / 06 / 11$ & $04: 55: 07.41$ & 35.637 & -115.663 & 3.8 & 12 \\
\hline $1974 / 06 / 11$ & $12: 40: 40.98$ & 37.643 & -115.320 & 4.4 & 19 \\
\hline $1974 / 06 / 11$ & $12: 53: 08.15$ & 37.595 & -115.296 & 3.9 & 8 \\
\hline $1974 / 07 / 05$ & $13: 10: 32.79$ & 35.937 & -117.088 & $3 \cdot 3$ & 6 \\
\hline $1974 / 07 / 06$ & $06: 10: 41.11$ & 38.806 & -119.616 & 3.7 & 12 \\
\hline $1974 / 07 / 07$ & $07: 22: 52.66$ & 35.909 & -117.827 & $3 \cdot 4$ & 7 \\
\hline $1974 / 07 / 31$ & $07: 31: 27.45$ & 35.695 & -117.691 & 4.0 & 8 \\
\hline $1974 / 08 / 13$ & $14: 44: 21.89$ & 38.605 & -119.040 & 3.4 & 9 \\
\hline $1974 / 08 / 19$ & $01: 03: 43.06$ & 36.277 & -118.334 & $2 \cdot 6$ & 10 \\
\hline $1974 / 08 / 21$ & $19: 38: 04.05$ & 38.012 & -118.765 & $3 \cdot 4$ & 10 \\
\hline $1974 / 08 / 25$ & $10: 10: 59.53$ & 35.855 & -117.662 & $4 \cdot 1$ & 13 \\
\hline $1974 / 08 / 25$ & $12: 21: 58 \cdot 45$ & 35.876 & -117.691 & 3.7 & 17 \\
\hline $1974 / 09 / 07$ & $23: 12: 07.23$ & 38.164 & -118.751 & 3.5 & 8 \\
\hline $1974 / 11 / 05$ & $12: 39: 12: 40$ & 38.086 & -118.873 & $3 \cdot 5$ & \\
\hline $1974 / 11 / 14$ & $16: 20: 38.78$ & 37.884 & -118.146 & 4.0 & \\
\hline $1974 / 11 / 18$ & $02: 04: 52.22$ & 37.633 & -118.799 & 3.8 & \\
\hline $1974 / 11 / 21$ & $12: 55: 16.83$ & 37.522 & $-118.3+4$ & $2 \cdot 6$ & \\
\hline $1974 / 12 / 07$ & $10: 08: 30.66$ & 37.138 & -117.839 & $3 \cdot 4$ & \\
\hline
\end{tabular}

